\title{
Ötvenkét bogárcsalád adatai a Látrányi Puszta Természetvédelmi Területről (Coleoptera)
}

\author{
Merkl OtTó ${ }^{1}$ Podlussány AtTIla ${ }^{2}$ \& SZAlóKi Dezsō ${ }^{3}$ \\ Hungarian Natural History Museum, H- 1088 Budapest, Baross u. 13., Hungary, E-mail: merkl@zoo.zoo.nhmus.hu \\ ${ }^{2}$ H-1111 Budapest, Bercsényi u. 10., Hungary \\ ${ }^{3}$ Radnóti Miklós Teacher Training School, H-1146 Budapest, Cházár András u. 10., Hungary \\ E-mail: meloe@serverradnoti-elte.sulinethu
}

Merkl O., PodlussánY A. \& Szalóki D.: Species of 52 beetle families (Coleoptera) from the Látrányi Puszta Nature Conservation Area (Somogy county, Hungary)

Abstract: A list of 552 beetle species known to occur in a nature reserve at Látrány (Somogy county, Hungary) belonging to 52 families (Dytiscidae, Hydrophilidae, Helophoridae, Georissidae, Histeridae, Agyrtidae, Silphidae, Leiodidae, Scydmaenidae, Staphylinidae, Eucinetidae, Byrrhidae, Dryopidae, Throscidae, Elateridae, Lampyridae, Cantharidae, Dermestidae, Anobiidae, Cleridae, Melyridae, Nitidulidae, Monotomidae, Silvanidae, Cucujidae, Erotylidae, Byturidae, Bothrideridae, Cerylonidae, Coccinellidae, Mycetophagidae, Ciidae, Melandryidae, Zopheridae, Tenebrionidae, Oedemeridae, Meloidae, Pythidae, Pyrochroidae, Salpingidae, Anthicidae, Aderidae, Nemonychidae, Anthribidae, Rhynchitidae, Attelabidae, Apionidae, Nanophyidae, Curculionidae, Brachyceridae, Dryophthoridae, Scolytidae) is given. The first reliably identified specimen of Carpelimus subtilis (Erichson, 1839) (Staphylinidae) from Hungary is recorded from this area. Hungarian localities of Glischrochilus quadripunctatus ((Linnaeus, 1758) (Nitidulidae) and Brachycerus foveicollis Gyllenhal, 1833 (Brachyceridac) are depicted on UTM maps.

Key words: Carpelimus subtilis, Somogy county, nature conservation

\section{Bevezetés}

A Látrányi Puszta Természetvédelmi Terület Somogy megyében, Látrány községtő1 délre a Balatonlellét Kaposvárral összekötő 67-es út mellett található. Területe 223,6 hektár. Valaha a Balaton lefüződött öble, majd tó volt; ennek bizonyítéka a talaj, amely balatoni üledék eredetü meszes homok (GARAMI \& GARAMI 1997). A tájat ma hosszú, közepes magasságú buckák uralják, amelyek tetejét homoki gyepek borítják. A mélyedésekben meggyülik a víz, itt mocsárrétek és láprétek alakultak ki. A területet kelet felöl a Tetves-patak határolja, amelyet égeres és füzes kísér. A homoki gyepekben sajnos a degradáció jelei is mutatkoznak: néhol invázív gyomok foltjai, máshol illegális homokbányászat okozta gödrök tarkítják a vidéket. Jelentős a galagonyával történő becserjésedés, a nyugati részen pedig fiatal tölgyes és aránylag nagy kiterjedésü erdeifenyő-telepités látható. A területet 1992-ben nyilvánították védetté, elsősorban változatos és értékes növényvilága miatt. 


\section{A vizsgált anyag}

A jelen dolgozat alapját képező vizsgálati anyagot Ábrahám Levente, Kondorosy Elöd, Merkl Ottó, Podlussány Attila, Rozner György, Rozner István, Szalóki Dezsö és Szinetár Csaba gyüjtötték 1992-től 2002-ig (a gyüjtés intenzívebb szakasza 2001-2002ben zajlott). A bizonyító példányok a Somogy Megyei Múzeumban (Kaposvár), a Magyar Természettudományi Múzeumban (Budapest), valamint Podlussány Attila (Budapest), Rozner György (Kisberény), Rozner István (Budapest) és Szalóki Dezső (Budapest) magángyüjteményeiben találhatók.

\section{Eredmények és értékelés}

A gyüjtött anyagból az ismertetésre kerülő családokat illetően összesen 552 fajt sikerült meghatározni, közülük 73 Somogy megyéböl első ízben kerül közlésre.

A terület bogárfaunáját aligha tekinthetjük teljesen feltártnak. Az elökerült fajok alapján mégis jellegzetes homokpusztai faunakép rajzolódik ki elöttünk. Ennek jellegzetes elemei például a nyár derekán a virágokon sokfelé látható Cerocoma schreberi és Zonitis praeusta hólyaghúzó bogarak, valamint a Brachycerus foveicollis ormányosalkatú bogár.

A nedves területekre jellemző fajok aránylag kis számban kerültek elö; ennek alighanem az az oka, hogy a területen átfolyó Tetves-patakot, illetve a nedves réteket a gyüjtők kevésbé kutatták. A területről kimutatott vízibogarakat szinte kizárólag lámpázással vagy késő délutáni autós hálózással fogták. A nedves területeken lerakott talajcsapdákban tömegesen jelentkezett a Dryops ernesti fülescsápúbogár. A füzesben gyüjtött fajok közül érdemes kiemelni a Sospita vigintiguttata katicabogarat, amely hazánk ártéri és mocsárerdeinek viszonylag ritka lakója.

$\mathrm{Az}$ ültetett fenyvesekre jellemző fajok közül érdemes említeni a Glischrochilus quadripunctatus fénybogarat, amely Látrányon kívül csupán hat dunántúli és egy északmagyarországi lelőhelyről ismert. A hazánkban védett lapos sárkánybogárnak (Pytho depressus) ez a harmadik lelöhelye Magyarországon (lásd SÁR et al. 2001). Kifejezetten a fenyvesekhez kötődnek az Anatis ocellata, Harmonia quadripunctata és Myrrha octodecimguttata katicabogarak.

Az összesen 282 kimutatott ormányosalkatú faj nagy része olyan növényeken él, amelyek bolygatott területekre jellemzőek. A fákon élő 46 faj a puszta szélén lévő fiatal tölgyesből és az ültetett fenyvesből került elö. A homoki gyepekre jellemző fajok száma kb. 30. Néhány ritkábban elöforduló fajt is kimutattuk: Ceutorhynchus interjectus, Eucoeliodes mirabilis, Glocianus fennicus, Ceratapion armatum, Rhynchites cupreus, valamint a már említett Brachycerus foveicollis.

\section{Az elökerült fajok jegyzéke}

A családok klasszifikációja általában LAWRENCE és NEWTON (1995) általánosan elfogadott beosztását követi. A holyvafélék (Staphylinidae) alcsaládjainak sorrendjét HERMAN (2001), Az ormányosalkatúak (Curculionoidea) családjainak sorrendjét pedig AlONSO-ZARAZAGa és LYAL (1999) szerint adtuk meg. A tárgyalt családok a következö alrendekbe és családsorozatokba tartoznak: 
Caraboidea alrend: Dytiscidae.

Polyphaga alrend:

Hydrophiloidea családsorozat: Hydrophilidae, Helophoridae, Georissidae,

Histeridae.

Staphylinoidea családsorozat: Agyrtidae, Silphidae, Leiodidae, Scydmaenidae,

Staphylinidae.

Scirtoidea családsorozat: Eucinetidae.

Byrrhoidea családsorozat: Byrrhidae, Dryopidae.

Elateroidea családsorozat: Throscidae, Elateridae, Lampyridae, Cantharidae.

Bostrichoidea családsorozat: Dermestidae, Anobiidae.

Cleroidea családsorozat: Cleridae, Melyridae.

Cucujoidea családsorozat: Nitidulidae, Monotomidae, Silvanidae, Cucujidae,

Erotylidae, Byturidae, Bothrideridae, Cerylonidae, Coccinellidae.

Tenebrionoidea családsorozat: Mycetophagidae, Ciidae, Melandryidae, Zopheridae,

Tenebrionidae, Oedemeridae, Meloidae, Pythidae, Pyrochroidae, Salpingidae,

Anthicidae, Aderidae.

Curculionoidea családsorozat: Nemonychidae, Anthribidae, Rhynchitidae,

Attelabidae, Apionidae, Nanophyidae, Curculionidae, Brachyceridae,

Dryophthoridae, Scolytidae.

A csillaggal (*) jelölt fajok Somogy megyéből első ízben kerülnek közlésre (lásd CSABAI 2001, MERKL 2001, PODLUSSÁNy 2001, ROZNER 2001, RudNER 2001, SZALÓKI 2001).

\section{Dytiscidae}

(mcghatározta: Csabai Zoltán és Merkl Ottó)

Agabus bipustulatus (Linnacus, 1767) - Látrány: Birkás-legelö, 2001. X. 5., Rozner Gy.

Colymbetes fuscus (Linnaeus, 1758) - Látrány, 2001. IV. 12., Rozner G.

Hygrotus impressopunctatus (Schaller, 1783) Látrány, 1999. VI. 7., Ábrahám L.; Látrány: Kollátilegelö, 2000. IV. 11., Rozner Gy.

Hydroglyphus geminus (Fabricius, 1792) Látrány: Birkás-legelő, autós hálózás, késō délután, 2002. V. 4., Merkl O.; Látrány: Kolláti-legelö, fényre, 2002. VI. 19., Ábrahám L.

Hydroporus angustatus Sturm, 1835 - Látrány: Kolláti-legclö, fényrc, 2001. Vl. 19., Ábrahám L.; Látrány: Kolláti-legelö, fényre, 2002. VI. 19., Ábrahám $L$.

Hydroporus planus (Fabricius, 1781) - Látrány: Birkás-legclö, autós hálózás, késő délután, 2002. V. 4., Merkl O.

llybius ater (Dc Geer, 1774) - Látrány, 2001. V. 16., Ábrahám L.

Ilybius fuliginosus (Fabricius, 1792) - Látrány, 2001. V. 16., Ábrahám L.; Látrány: Birkás-legclö, fényre, 2001. VIIl. 18., Ábrahám L.

llybius quadriguttatus (Lacordaire, 1835) Látrány, 1999. V1. 2., Ábrahám L.; Látrány, 1999. V1. 7., Ábrahám L.

Laccophilus minutus (Linnaeus, 1758) - Látrány: Kolláti-legelö, fényre, 2001. VI. 19., Ábrahám L.
Rhantus bistriatus (Bergsträsser, 1778) Látrány, 1999. VI. 7., Ábrahám L.

Rhantus frontalis (Marsham, 1802) - Látrány, 2001. VII. 31., Szalóki D.; Látrány, fénycsapda, 2002. VI. 19., Rozner Gy.

Rhantus suturalis (Macleay, 1825) - Látrány: Kolláti-legelö, fényre, 2001. VI. 19., Ảbrahám L.; Látrány, 2001. VII. 31., Szalóki D.

\section{Hydrophilidae}

(meghatározta: Csabai Zoltán és Merkl Ottó)

Anacaena limbata (Fabricius, 1792) - Látrány: Birkás-legelö, 1998. IV. 24., Rozner Gy.

Berosus frontifoveatus Kuwert, 1890 - Látrány: Kolláti-legelö, fényre, 2001. VI. 19., Ábrahám L.; Látrány: Kolláti-legelő, fényre, 2002. VI. 19., Ábrahám L.

Berosus signaticollis (Charpentier, 1825) Látrány: Kolláti-legelő, fényre, 2001. VI. 19., Ábrahám L.; Látrảny: Birkás-legelő, autós hálózás, késő délután, 2002. V. 4., Merkl O.

*Berosus spinosus (Steven, 1808) - Látrány: Kolláti-legelō, fényre, 2001. VI. 19., Ábrahám L.; Látrány: Birkás-legelö, f́ñyre, 2001. VIIl. 18., Ábrahám L. Cercyon haemorrhoidalis (Fabricius, 1792) Látrány: Kolláti-legelő, 1999. V. 2., Rozner Gy. Cercyon laminatus Sharp, 1873 - Látrány: Kolláti-legelő, fényre, 2002. VI. 19., Ábrahám L.

Cercyon lateralis (Marsham, 1802) - Látrány, 1999. IV. 30., Rozner Gy. 
Cercyon marinus Thomson, 1853 - Látrány: Kolláti-legelö, fényrc, 2002. VI. 19., Ábrahám L. Cercyon nigriceps (Marsham, 1802) - Látrány: Kolláti-legelő, fényre, 2001. VI. 19., Ábrahám L. Cercyon pygmaeus (Illiger, 1801) - Látrány: Kolláti-legelö, fényrc, 2001. Vl. 19., Ábrahám L.; Látrány: Kolláti-legelö, fényrc, 2002. VI. 19., Ábrahám L.

Cercyon quisquilius (Linnacus, 1761) - Látrány:

Duda-tetö, 1998. III. 30-31., Rozner Gy.

Cercyon sternalis Sharp, 1918 - Látrány: Kollátilcgclö, fényre, 2002. VI. 19., Ábrahám L.

Cercyon unipunctatus (Linnacus, 1758) Látrány: Kolláti-legelö, fényre, 2002. VI. 19., Ábrahám L.

Coelostoma orbiculare (Fabricius, 1775) -

Látrány: Kolláti-legclö, fényre, 2002. VI. 19., Ábrahám L.

Cryptopleurum minutum (Fabricius, 1775) -

Látrány: Kolláti-legelő, fényre, 2002. VI. 19., Ábrahám L.

Enochrus bicolor (Fabricius, 1792) - Látrány,

1999. VI. 2., Ábrahám L.; Látrány, 2001. VII. 31., Szalóki D.; Látrány: Kolláti-legelő, fényre, 2001. VI. 19., Ábrahám L.

Helochares lividus (Forster, 1771) - Látrány:

Kolláti-legelö, fényre, 2001. V1. 19., Ábrahám L.

Helochares obscurus (O. F. Müller, 1776) -

Látrány, 2001. VII. 31., Szalóki D.

Hydrobius fuscipes (Linnaeus, 1758) - Látrány, 1999. VI. 7., Ábrahám L.; Látrány, legelő, 1998. IV. 24., Rozner Gy.; Látrány, 2001. VII. 31 ., Szalóki D.; Látrány, 2001. VIII. 16., Ábrahám L.; Látrány: Kolláti-legclö, fćnyrc, 2001. VI. 19., Ábrahám L. Hydrochara caraboides (Linnacus, 1758) Látrány, fénycsapda, 2002. VI. 19., Rozner Gy. Laccobius minutus (Linnacus, 1758) - Látrány:

Kolláti-legelő, fényre, 2002. VI. 19., Ábrahám L. Laccobius sinuatus Motshulsky, 1849 - Látrány:

Kolláti-legelö, fényre, 2002. V1. 19., Ábrahám L.

\section{Helophoridae}

(meghatározta: Csabai Zoltán)

Helophorus brevipalpis Bcdel, 1881 - Látrány: Kolláti-lcgclő, fényrc, 2001. Vl. 19., Ábrahám L.; Látrány: Kolláti-legclö, fényre, 2002. VI. 19., Ábrahám L.

Helophorus montenegrinus Kuwert, 1885 Látrány: Kolláti-legclö, fényre, 2001. VI. 19., Ábrahám L.; Látrány: Kolláti-legelő, fényre, 2002. VI. 19., Ábrahám L.

\section{Georissidae}

(mcghatározta: Mcrkl Ottó)

*Georissus crenulatus (Rossi, 1794) - Látrány: Kolláti-legclö, talajcsapda, 1999. IV. 15.-V.22., Rozner Gy.

\section{Histeridae}

(meghatározta: Rozner István)

*Acritus nigricornis (Hoffmann, 1803) Látrány: Birkás-legelő, autós hálózás, késő délután, 2002. V. 4., Merkl O.

Carcinops pumilio (Erichson, 1834) - Látrány: Birkás-legelö, 2001. V11. 19., Rozner Gy.

Chalcionellus decemstriatus (Rossi, 1792) Látrány: Kolláti-legelő, 1999. V. 22., Rozner Gy.; Látrány, 1999. VI. 2., Rozner Gy.; Látrány, 1999. VII. 12., Rozner Gy,; Látrány: Kolláti-legelö, 2000. V. 13., Rozner Gy.

*Gnathoncus nannetensis (Marseul, 1862) Látrány: Birkás-legelő, autós hálózás, késő délután, 2002. V. 4., Merkl O.

*Gnathoncus rotundatus (Kugelann, 1792) Látrány: Birkás-legelö, 2001. VII. 19., Rozner Gy.

Hister uncinatus Illiger, 1807 - Látrány: Kollátilegelö, 1999. V. 22., Rozner Gy.

Hololepta plana (Sulzer, 1776) - Látrány, 2001. II. 23., Rozner Gy.

Margarinotus brunneus (Fabricius, 1775) Lảtrány: Birkás-legelő, (5. számú terület), kutyadögröl, 2001. VII. 5., Mcrkl O.; Látrány: Birkás-legelö, talajcsapda, 2002. VI. 13-VI1. 15., Rozner Gy.

Margarinotus carbonarius (Hoffmann, 1803) Látrány: talajcsapda, 2002. VI. 16., Szinetár Cs.

Onthophilus affinis Redtenbacher, 1849 Látrány: Kolláti-legelő, talajcsapda, 1999. III. 5-III. 31., Rozncr Gy.; Látrány: Kolláti-legelő, talajcsapda, 1999. IV. 15-V. 22., Rozner Gy.

Onthophilus punctatus (O. F. Müller, 1776) Látrány: Birkás-legelő, talajcsapda, 1999. III. 5-III. 31., Rozner Gy.; Látrány: Kolláti-legelő, 2001. III. 10., Rozner Gy.

Pactolinus inaequalis (Olivier, 1789) - Látrány: Kolláti-legelō, 1999. V1. 2., Rozner Gy.; Látrány: Kolláti-legelö, 1999. IX. 7., Rozner Gy. Rozner (2001) Pachylister inaequalis kombinációval emliti Somogy megyéböl.

Paromalus parallelepipedus (Herbst, 1792) Látrány, 2001. IV. 18., Rozner Gy.

*Platylomalus complanatus (Panzer, 1797) Látrány, 2001. II. 23., Rozner Gy.

Platysoma minor (Rossi, 1792) - Látrány: legelö, 1998. Vl. 22., Rozner Gy. Rozner (2001) Platysoma frontale (Paykull, 1798) néven emliti Somogy megyćböl.

Saprinus aeneus (Fabricius, 1775) - Látrány: Kolláti-legelö, 1999. V. 22., Rozner Gy.; Látrány: Kolláti-lcgelő, 1999. Vl., Rozncr Gy.; Látrány: Birkás-legelő, (5. számú terület), kutyadögről, 2001. VII. 5., Merkl O.; Látrány: Kolláti-legelö, (1. számú tcrülct), fühálózás, 2001. VII. 5., Merkl O.; Látrány: Birkás-legclő, 2002. V. 2., Rozner Gy.; Látrány: Birkás-legclö, talajcsapda, 2002. VI. 13-VIl. 15., Rozner Gy. 
1.

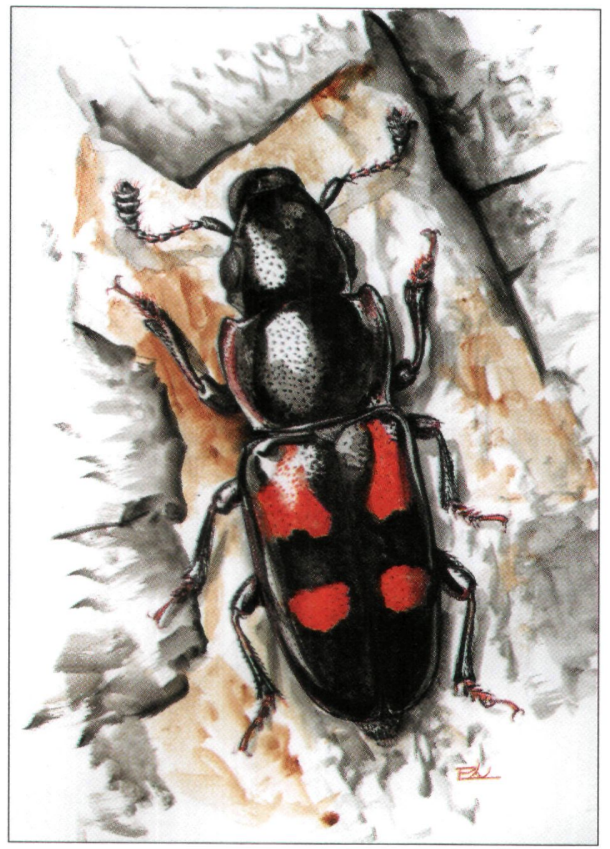

2.

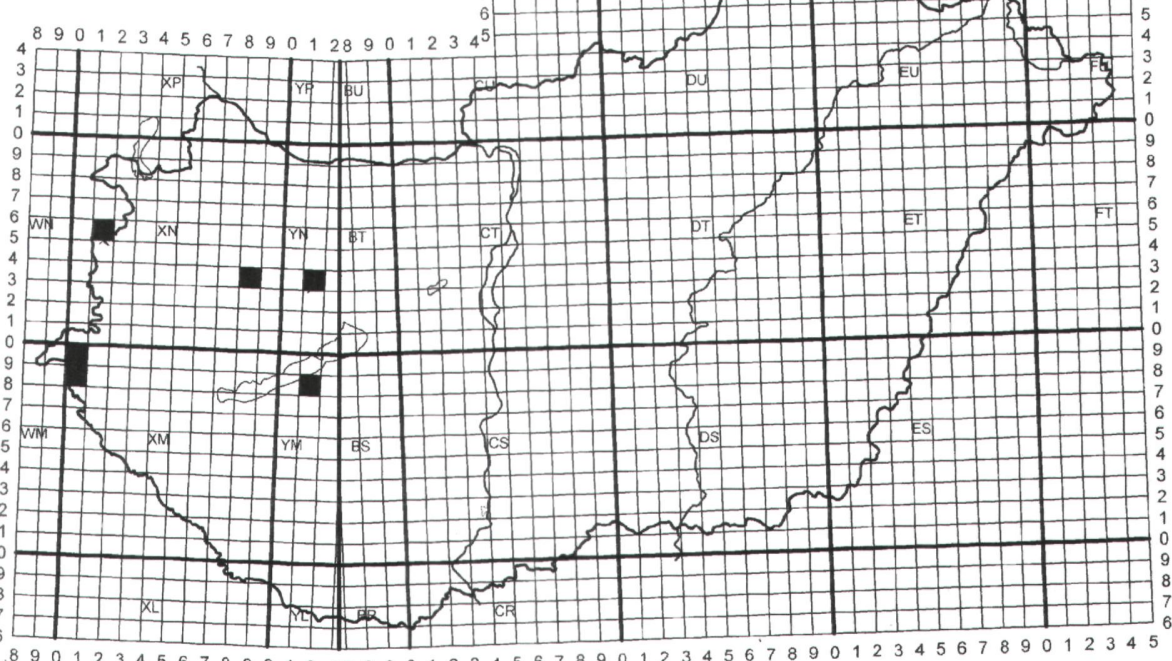

1-2. ábra. 1 = a Glischrochilus quadripunctatus (Linnaeus, 1758) habitusa és 2 = magyarországi lelőhelyadatai.

Figs 1-2. 1 = Habitus and 2 = Hungarian localities of Glischrochilus quadripunctatus (Linnaeus, 1758) 
3.

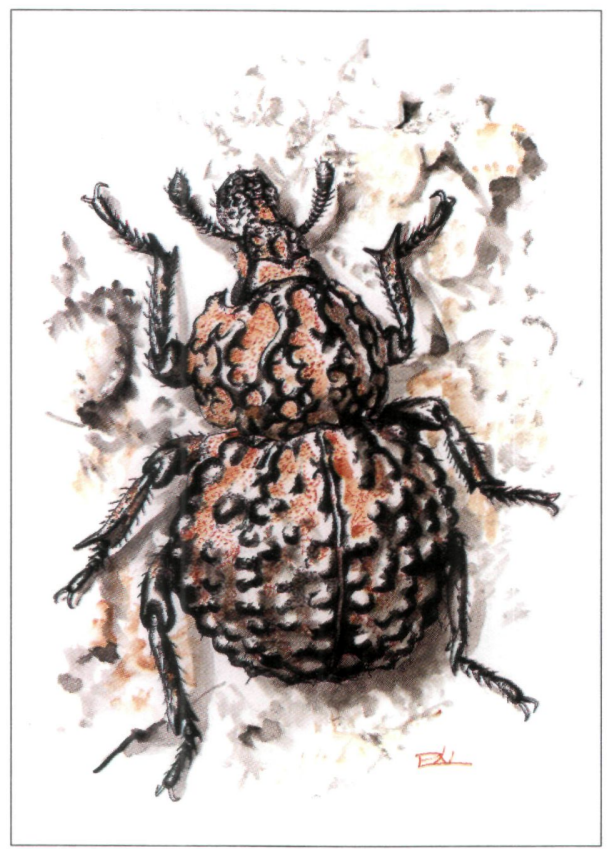

4.

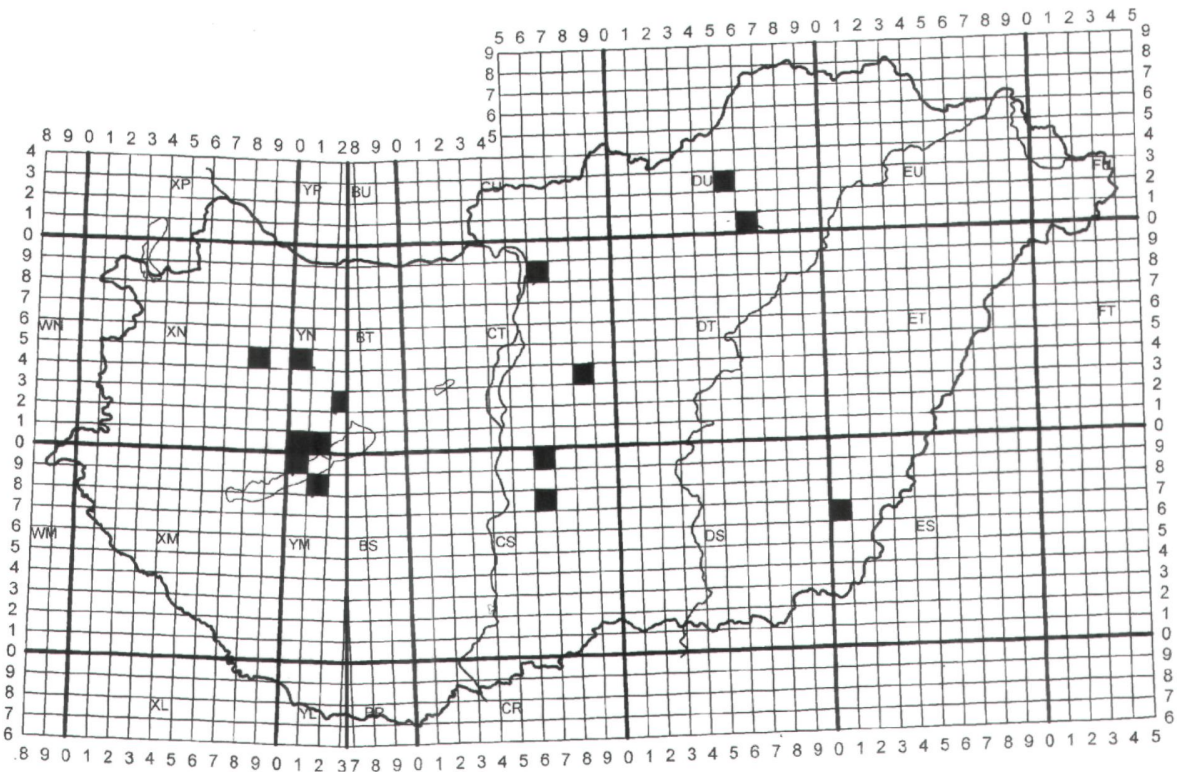

3-4. ábra. 3 = a Brachycerus foveicollis Gyllenhal, 1833 habitusa és 4 = magyarországi lelőhelyadatai

Figs 3-4. 3 = Habitus and $4=$ Hungarian localities of Brachycerus foveicollis Gyllenhal, 1833 
Saprinus georgicus Marseul, 1862 - Látrány: Kolláti-legelö, 1999. VI., Rozner Gy.; Látrány: Birkás-legelö, 2001. VII. 19., Rozner Gy.

Saprinus planiusculus Motschulsky, 1849 Látrány: Birkás-legelő, 2001. VII. 19., Rozner Gy.; Látrány, 2001. IX. 10, Rozner Gy.

Saprinus semistriatus (Scriba, 1790) - Látrány: Birkás-legelő, (5. számú terület), kutyadögröl, 2001. VII. 5., Merkl O.; Látrány: Birkás-legelö, 2001. VII. 19., Rozner Gy.

Saprinus subnitescens Bickhard, 1909 - Látrány: Birkás-legelö, (5. számú terület), kutyadögröl, 2001. VII. 5., Merkl O.

\section{Agyrtidae}

(meghatározta: Merkl Ottó)

Agyrtes bicolor Laporte de Castelnau, 1840 Látrány: Birkás-legelő, akácos, talajcsapda, 2002. III. 14.-IV. 2., Rozner Gy.

\section{Silphidae}

(meghatározta: Rozner István)

Necrodes littoralis (Linnaeus, 1758) - Látrány: Birkás-lcgelö, fényre, 2001. VIII. 18., Ábrahám L. Nicrophorus humator Olivier, 1790 - Látrány: Birkás-legclö, egyelés, 2001. VII. 19., Rozner Gy. Nicrophorus vespillo (Linnaeus, 1758) - Látrány: Birkás-legelö, egyelés, 2001. IV. 18., Rozner Gy.; Látrány: Birkás-legelö, cseres, boros csapda, 2002. VI. 13-VIl. 15., Rozner Gy; Látrány: Birkás-legelö, talajcsapda, 2002. VI. 13-VII. 15., Rozner Gy.

Nicrophorus vespilloides Herbst, 1784 - Látrány: Birkás-legelő, akácos, talajcsapda, 2002. VI. 13-VII. 15., Rozner Gy.

Oiceoptoma thoracica (Linnaeus, 1758) - Látrány: Birkás-legelö, talajcsapda, 1998. IV. 24-V. 15., Rozner Gy.; Látrány: Birkás-legelő, cseres, talajcsapda, 2002. VI. 13-VII. 15., Rozner Gy.; Látrány: Birkás-legelö, akácos, 2002. VI. 13-VIl. 15., Rozner Gy.

Phosphuga atrata Linnaeus, 1758 - Látrány: Birkás-legclö, talajcsapda, 1999. V. 22-VI. 24., Rozner Gy. Silpha carinata Herbst, 1783 - Látrány: Birkáslegelő, talajcsapda, 1998. IV. 5-V. 15., Rozner Gy.; Látrány: Birkás-legelő, talajcsapda, 1999. IV. 1-IV. 14., Rozner Gy.; Látrány: Birkás-legelö, talajcsapda, 1999. V. 22., Rozner Gy.; Látrány: Birkás-legelö, talajcsapda, 1999. V. 22-IV. 24., Rozner Gy.; Látrány: Birkás-legelö, cseres, talajcsapda, 2002. IV. 13-VII. 15., Rozner Gy.; Látrány: Birkás-legelő, akácos, talajcsapda, 2002. Vi. 13-VII. 15., Rozner Gy.

Silpha obscura Linnaeus, 1758 - Látrány: Birkás-legelö, talajcsapda, 1998. IV. 24-V. 15., Rozner Gy.

Thanatophilus rugosus (Linnaeus, 1758) Látrány: Birkás-legelő, egyelés, 1999. III. 31., Rozner Gy.

Thanatophilus sinuatus (Fabricius, 1775) Látrány: Birkás-legelő, egyclés, 1999. III. 31.,
Rozner Gy.; Látrány: Birkás-legelő, egyelés, 1999. IV. 14., Rozner Gy.; Látrány: Birkás-legelő, egyelés, 2001. IV. 18., Rozner Gy.; Látrány: Birkás-legelö, egyelés, 2001. VII. 19., Rozner Gy.

\section{Leiodidae}

(meghatározta: Merkl Ottó és Jan Růžička)

Agathidium laevigatum Erichson, 1845 Látrány: Birkás-legelő, cseres, talajcsapda, 2002. IV. 2-26., Rozner Gy.

Catops grandicollis Erichson, 1837 - Látrány: Birkás-legelō (3. számú terület), talajcsapda, 2002. III. 14.-IV. 2., Rozner Gy.

* Choleva oblonga Latreille, 1807 - Látrány: Birkás-legelő (3. számú terület), talajcsapda, 2002. III. 14.-IV. 2., Rozner Gy.

Colenis immunda (Sturm, 1807) - Látrány: Birkás-legelö, autós hálózás, késő délután, 2002. V. 4., Merkl $\mathrm{O}$.

*Hydnobius punctatus (Sturm, 1807) - Látrány: Kolláti-legelő, 2001. IV. 26., Rozner I.

*Leiodes brunnea (Sturm, 1807) - Látrány: Birkás-legelő, autós hálózás, késő délután, 2002. V. 4., Merkl $\mathrm{O}$.

*Leiodes polita Marsham, 1802 - Látrány: Kolláti-lcgelő, 2001. IV. 26., Rozner I.; Látrány: Kolláti-legelö, 2001. X. 5., Rozner I.

Nargus velox (Spence, 1815) - Látrány, talajcsapda, 1998. IV. 24-V. 15., Rozner Gy.

\section{Scydmaenidae}

(meghatározta: Rudner József)

*Neuraphes elongatulus (Müller et Kunze, 1822) - Látrány: Birkás-legelő, autós hálózás, kćső délután, 2002. V. 4., Merkl O.

Stenichnus collaris (Müller et Kunze, 1822) Látrány: Birkás-legelő, autós hálózás, késő délután, 2002. V. 4., Merkl O.

Stenichnus scutellaris (Müller et Kunze, 1822) Látrány: Birkás-legelő, autós hálózás, késő délután, 2002. V. 4., Merkl O.

\section{Staphylinidae}

\section{Micropeplinae}

(meghatározta: Merkl Ottó)

*Micropeplus porcatus (Fabricius, 1792) Látrány: Birkás-legelő, autós hálózás, késő délután, 2002. V. 4., Merkl O.

\section{Omaliinae}

(meghatározta: Merkl Ottó)

Lesteva longoelytrata (Goeze, 1777) - Látrány: Birkás-legelö, autós hálózás, késő délután, 2002. V. 4., Merkl O. 
Omalium caesum (Gravenhorst, 1806) - Látrány: Birkás-legclő, autós hálózás, késő délután, 2002. V. 4., Merkl O.

*Phloeonomus pusillus (Gravenhorst, 1806) Látrány: Birkás-legelő, autós hálózás, késő délután, 2002. V. 4., Merkl O.

Phloeostiba plana (Paykull, 1792) - Látrány: Birkás-legelö, cseres, talajcsapda, 2002. Ill. 14-IV. 2., Rozner Gy.

\section{Proteininae}

(meghatározta: Merkl Ottó)

Proteinus ovalis Stephens, 1834 - Látrány: Birkás-legelö, autós hálózás, késö délután, 2002. V. 4. Mcrkl O.

\section{Pselaphinae}

(meghatározta: Rudner József)

Trissemus antennatus serricornis (Schaum, 1838) - Látrány: Birkás-legelő, autós hálózás, késő délután, 2002. V. 4., Merkl O.

\section{Tachyporinae}

(meghatározta: Fülöp Dávid)

*Bolitobius castaneus (Stephens, 1832) Látrány: Birkás-lcgclő (5. számú terület), fühálózás, 2002. V. 4., Merkl O.

Ischnosoma splendida (Gravenhorst, 1806) Látrány: Birkás-legelő (5. számú terület), fühálózás, 2002. V. 4., Merkl O. Merkl (2001) Mycetoporus splendidus kombinációval említi Somogy megyéből.

\section{Aleocharinae}

(meghatározta: Mcrkl Ottó)

*Zyras (Lepla) lugens (Gravenhorst, 1802) Látrány: Birkás-legelő, autós hálózás, késő délután, 2002. V. 4., Merkl O.

\section{Scaphidiinae}

(meghatározta: Merkl Ottó)

Scaphidium quadrimaculatum (Olivier, 1790) Látrány: Birkás-legelő, autós hálózás, késő délután, 2002. V. 4., Merkl O.

* Scaphisoma boleti (Panzer, 1793) - Látrány: Birkás-legelö, fühálózás, 1999. VII. 12., Rozner Gy.

Scaphium immaculatum (Olivier, 1790) Látrány: Birkás-legclö, talajcsapda, 1999. V. 22.-VI. 24., Rozner Gy.

\section{Oxytelinae}

(meghatározta: Makranczy György)
Bledius opacus (Block, 1799) - Látrány: Birkáslcgelő, autós hálózás, késő délután, 2002. V. 4., Merkl o.

*Carpelimus gracilis (Mannerheim, 1830) Látrány: Birkás-legelő, autós hálózás, késő délután, 2002. V. 4., Merkl O.

*Carpelimus subtilis (Erichson, 1839) - Látrány: Birkás-legclō, autós hálózás, kćső délután, 2002. V. 4., Merkl O. - A fajnak cz az clsö hitcles magyarországi példánya (megtalálható a Magyar Természettudományi Múzeumban). Viszonylag sok adata ismert Boszniából, és cgy-két példánya a Felvidékröl (Szlovákia). Az cddig közölt magyar példányok (amennyiben vannak ilyenek) téves határozások. (Makranczy György, személyes közlés).

Coprophilus striatulus (Fabricius, 1792). Látrány: Birkás-legelö, autós hálózás, késő délután, 2002. V. 4., Merkl O.

\section{Paederinae}

(meghatározta: Merkl Ottó)

Medon fusculus (Manncrheim, 1830) - Látrány: Birkás-legelö, autós hálózás, késő délután, 2002. V. 4., Mcrkl O.

\section{Staphylininae}

(meghatározta: Merkl Ottó)

*Ontholestes murinus (Linnaeus, 1758) Látrány: Birkás-legelö (5. számú terület), kutyadögröl, 2002. V. 4., Merkl O.

\section{Steninae}

(meghatározta: Volker Puthz)

*Stenus (Hemistenus) pallitarsis Stcphens, 1833 Látrány: Birkás-legelő, 2001. IV. 26., Podlussány A.

\section{Eucinetidae} (meghatározta: Merkl Ottó)

*Eucinetus haemorrhoidalis (Germar, 1818) Látrány: Birkás-legelő, 2001. IV. 26., Podlussány A.

\section{Byrrhidae}

(meghatározta: Merkl Ottó)

Chaetophora spinosa (Rossi, 1794) - Látrány: Birkás-lcgelő, autós hálózás, kćső délután, 2002. V. 4., Mcrkl O.

*Cytilus sericeus (Forster, 1771) - Látrány: Birkás-lcgelö, (5. számú terület), fühálózás, 2002. V. 4., Merkl $\mathrm{O}$.

Lamprobyrrhulus nitidus (Schaller, 1783) Látrány: Birkás-legelő, egyclés, 2002. IV. 2., Rozner Gy. 


\section{Dryopidae}

(meghatározta: Merkl Ottó)

*Dryops ernesti Gozis, 1832 - Látrány: Birkás-

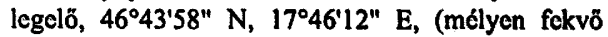
rész, $20-30 \mathrm{~cm}$ magas gyepszinttel, benne sok nöszöfüvel), 2002. VI. 16., talajcsapda, Szinetár Cs.; Látrány: Birkás-legelő, 4643'59" N, 1746'11" E, (mc̉lyen fckvö rész, 1-1,2 m magas sásos), 2002. VI. 16., talajcsapda, Szinetár Cs.; Látrány: Kolláti-legclö, 46 44'07" N, 1746'20" E, (füzes), 2002. VI. 16., talajcsapda, Szinetár Cs.

\section{Throscidae}

(mcghatározta: Merkl Ottó)

Trixagus dermestoides (Linnacus, 1767) Látrány: Birkás-lcgelő, nyíres, 2002. IV. 26., Podlussány $\mathrm{A}$.

\section{Elateridae}

(meghatározta: Merkl Ottó)

*Actenicerus sjaelandicus (O. F. Müller, 1764) Látrány: Kolláti-legelő (1. számú terullet), 2002. IV. 26., Rozner I.; Látrány: Birkás-legelő, (5. számú terület), fühálózás, 2002 . V. 4., Merkl 0.

Agriotes lineatus (Linnacus, 1758) - Látrảny: Birkás-legelö, 2001. IV. 26., Podlussány A.; Látrány: Nyírcs-legelő, 2002. IV. 26., Podlussány A.; Látrány: Birkás-legclö, 46²3'59" N, 17²6'11" E, (mélyen fekvö rész, 1-1,2 m magas sásos), 2002. Vl. 16., talajcsapda, Szinctár Cs.

Agriotes obscurus Linnaeus, 1758 - Látrány: Kolláti-Icgelő, 2001. IV. 26., Rozner I.

Agriotes sputator (Linnaeus, 1758) - Látrány, 2001. IV. 29., Szalóki D.; Látrány: Nyires-legelö, 2002. V. 26., Rozncr. 1.. Látrány: Birkás-legclö, (5. számú terület), fühálózás, 2002. V. 4., Merkı O.

Agrypnus murinus (Linnacus, 1758) - Látrány: Birkás-legelö, 2002. IV. 26., Podlussány A.; Látrány, 2001. IV. 29., Szalóki D.; Látrány: Bìrkás-legelö (5. számú terület), 2002. V. 26., Rozner. I.; Látrány: Nyires-lcgelö, 2002. IV. 26., Podlussány A.; Látrány: Nyircs-legclö, 2002. V. 26., Rozner. I.; Látrány: Kolláti-legelö, (1. számú terület), fühảlózás, 2001. VII. 5., Merkl O.; Látrány (2. számú terullet), 2001. VII. 10., Kondorosy E.; Látrány: Birkás-legelö, $46^{\circ} 44^{\prime} 03^{\prime \prime} \mathrm{N}, 17^{\circ} 45^{\prime} 44^{\prime \prime} \mathrm{E}$, (fiatal tölgyes), 2002 . VI. 16., talajcsapda, Szinetár Cs.

Ampedus elongatulus (Fabricius, 1787) Látrány: Nyires-legel6, 2002. IV. 26., Podlussány A.; Látrány: Birkás-legelō, (5. számú terület), fühálózás, 2002. V. 4., Mcrkl O.

Ampedus pomorum (Herbst, 1784) - Látrány, 1992. V1. 11, Ábrahám L.

Ampedus rufipennis (Stephens, 1830) - Látrány, lcgelö, 1998. IV. 24., Rozner Gy.
Ampedus sanguineus (Linnacus, 1758) Látrány: Birkás-legelö, (4. számú terület), egyelés, 2002. IV. 26., Rozner I.

*Ampedus sinuatus Germar, 1844 - Látrány, 2001. IV. 29., Szalóki D.; Látrány: Birkảs-legelő (5. számú terület), 2002. V. 26., Rozner. I.; Látrány: Birkás-legelö, (5. számú terullet), fühálózás, 2002. V. 4., Merkl 0.

*Anostirus purpureus (Poda, 1761) - Látrány: Birkás-legelō, (5. számú terület), fühálózás, 2002. V. 4., Merkl $O$.

Athous bicolor (Goeze, 1777) - Látrány: Birkáslegelö, fühálózás, 2001. VIl. 3., Rozner Gy.

Athous haemorrhoidalis (Fabricius, 1801) Látrány: Birkás-legelö, talajcsapda, 1999. V. 22-Vl. 24., lcg. G. Rozner; Látrány: Kolláti-legelö, 2002. IV. 26., Podlussány A.; Látrány: Kolláti-legelö (1. számú terullet), 2002. IV. 26., Rozner I.; Látrány: Nyíres-legelö, 2002. IV. 26., Podlussány A.; Látrảny: Bìrkáslegelö (5. számú terület), 2002. V, 26., Rozner. I.; Látrány: Birkás-legelö, 464ㄴ $03^{\prime \prime} \mathrm{N}, 17^{\circ} 45^{\prime} 44^{\prime \prime} \mathrm{E}$, (fiatal tölgyes), 2002. VI. 16., talajcsapda, Szinetár Cs.

Cidnopus pilosus (Leske, 1785) - Látrány: Birkás-legelo, 2002. IV. 26., Podlussány A.; Látrány: Birkás-legelō, (5. számú terület), fühálózás, 2002. V. 4., Merkl 0.

Dalopius marginatus (Linnaeus, 1758) Látråny: Birkás-legelő, nyires, 2002. IV. 26., Podlussány A.

*Dicronychus equisetoides (Lohse, 1978) Látrány, 2001. IV. 12., Szalóki D..

Dicronychus cinereus (Herbst, 1784) - Látrány, 2001. IV. 12., Szalóki D.; Látrány, 2001. IV. 29., Szalóki D.; Látrảny: Kolláti-legelö (1. számú terullet), 2002. IV. 26., Rozner 1.; Látrány: Birkás-legelö (5. számú terület), 2002. V. 26., Rozncr. I.; Látrány: Birkás-lcgelō, (5. számú terület), fühálózás, 2002. V. 4. , Merkl 0.

Dicronychus rubripes (Germar, 1824) - Látrảny, fühálózás, 1998. VI. 22., Rozner Gy.; Látrány, 2001. V. 13., Szalóki D.; Látrány, 2001. V. 18., Szalóki D.; Látrány: Birkás-legelő, (5. számú terullet), fühálózás, 2001. VII. 5., Merkl O.; Látrány: Kolláti-legelö (1. számú terület), 2002. IV. 26., Rozner I.; Látrány: Birkás-legelö, (5. számú terullet), fühálózás, 2002. V.4., Merkl O.; Látrány: Látrányi-puszta, fühálózás, 2002. Vl. 30., Merkl O.

*Drasterius bimaculatus (Rossi, 1790). Látrány: Birkás-legelö, cseres, talajcsapda, 2002. IV. 2-26., Rozner Gy.

Kibunea minuta (Linnacus, 1758) - Látrány, legelö, 1998. IV. 24., Rozner Gy.; Látrány: Birkás-legelö, fühálózás, 1999. IV. 14., Rozncr Gy.; Látrány, 2001. IV. 29., Szalóki D.; Látrány, 2001. V. 18., Szalóki D.; Látrány: Birkás-legclō, 2002. IV. 26., Podlussány A.; Látrány: Kolláti-legelő, 2002. IV. 26., Podlussány A.; Látrány: Kolláti-legelö (1. számủ terület), 2002. IV. 26., Rozncr I.; Látrány: Birkás-lege- 
lö, nyires, 2002. IV. 26., Podlussány A.; Látrány: Birkás-legelö (5. számú terület), 2002. V. 26., Rozner. I.; Látrány: Nyíres-legelő, 2002. V. 26., Rozner. I.; Látrány: Birkás-legelö, (5. számú terület), fühálózás, 2002. V. 4., Merkl O.

*Melanotus punctolineatus (Pelerin, 1829) Látrány, 2001. V. 18., Szalóki D.; Látrány: Kollátilegclö, (1. számú terület), 2002. IV. 26., leg. Rozner I.

*Melanotus villosus (Geoffroy, 1758) - Látrány, 1999. VI. 2., Ábrahám L.; Látrány: fénycsapda, 2001. VI. 25., Ảbrahám L.

Prosternon tessellatum (Linnaeus, 1758) Látrány: Birkás-legelő, 2001. IV. 26., Podlussány A.; Látrány, 2001. IV. 29., Szalóki D.; Látrány (2. számú terület), 2001. VIl. 10., Kondorosy E.; Látrány: Nyíres-legelö, 2002. IV. 26., Podlussány A.; Látrány: Birkás-legclö (5. számú terület), 2002. V. 26., Rozner. 1.; Látrány: Birkás-legelő, (5. számú terület), fühálózás, 2002, V. 4., Merkl O.; Látrány: Látrányipuszta, fühálózás, 2002. VI. 30., Merkl $\mathrm{O}$.

Synaptus filiformis (Fabricius, 1781) - Látrány, fühálózás, 1998. V. 15., Rozner Gy.; Látrány: Birkáslegclö (5. számú terület), 2001. IV. 26., Rozner I.; Látrány: Birkás-legelő, (5. számú terület), fühálózás, 2002. V. 4., Merkl O.

\section{Lampyridae}

(meghatározta: Szalóki Dezső)

Lampyris noctiluca (Linnaeus, 1767) - Látrány, 2001. VI. 25., fénycsapda, Ábrahám L.

\section{Cantharidae}

(meghatározta: Szalóki Dezső)

Cantharis fulvicollis Fabricius, 1792 - Látrány: Kolláti-legelö, (1. számú terület), fühálózás, 2001. VII. 5., Mcrkl O.; Látrány, 2001. VII. 31., Szalóki D.; Látrány (6. számú terület), 2001. VIl. 3., Rozner Gy.

Cantharis liburnica Dcpoli, 1912 - Látrány: Birkás-legelö, 2002. IV. 26., Podlussány A.

Cantharis rustica Fallén, 1807 - Látrány, 2001. IV. 29., Szalóki D.; Látrány: Birkás-legelö, 2002. IV. 26., Podlussány A.; Látrány: Kolláti-legelö, 2002. IV. 26., Rozner l.; Látrány: Nyíres-legelô, 2002. IV. 26., Rozner 1.

Malthodes dimidiaticollis (Rosenhauer, 1847) Látrány: Kolláti-legclő, 2001. IV. 26., Rozner 1.; Látrány: Birkás-legelö (5. számú terület), fühảlózva, 2001. IV. 29., Szalóki D.; Látrány: Birkás-legelö, 2001. IV. 26., Podlussány A.

Rhagonycha fulva (Scopoli, 1763) - Látrány (2. számú terület), 2001. VII. 10., Kondorosy E.; Látrány, 2001. VII. 31., Szalóki D.; Látrány: Kollátilegelö (1. számú terület), 2002. VII. 19., Kondorosy E.

Rhagonycha lignosa (O. F. Müller, 1764) Látrány: Birkás-legelő (5. számú terület), fühálózás, 2002. V. 4., Merkl O.
Rhagonycha limbata C. G. Thomson, 1864 Látrány: Kolláti-legelö, 2001. IV. 26., Rozner I.; Látrány: Birkás-legelő (5. számú terület), fühálózás, 2002. V. 4., Merkl O.

Silis ruficollis (Fabricius, 1775) - Látrány, 2001.

VII. 31., Szalóki D.

\section{Dermestidae}

(meghatározta: Merkl Ottó)

*Anthrenus (Anthrenus) pimpinellae Fabricius, 1775 - Látrány: Birkás-legelö, 2001. IV. 26., Podlussány A.

Attagenus pellio (Linnaeus, 1758) - Látrány: Birkás-legelō, (5. számú terület), fühálózás, 2002. V. 4., Merkl 0.

Dermestes frischii Kugelann, 1792 - Látrány: Birkás-legelő, (5. számú terület), kutyadögről, 2002. V. 4., Merkl O.

Dermestes murinus Linnaeus, 1758 - Látrány: Birkás-legelö, 1999. III. 31,, Rozner G.

*Dermestes undulatus Brahm, 1790 - Látrány: Birkás-legelō, autós hálózás, késő délután, 2002. V. 4., Merkl O.

* Megatoma undata (Linnaeus, 1758) - Látrány: Birkás-legelő, cseres, talajcsapda, 2002. III. 14-IV. 2., Rozner Gy.; Látrány: Birkás-legelő, cseres, talajcsapda, 2002. IV. 2-26., Rozner Gy.; Látrány: Birkás-legelö, (5. számú terület), fühálózás, 2002. V. 4., Merkl O.

\section{Anobiidae}

(meghatározta: Merkl Ottó)

Caenocara affinis (Sturm, 1837) - Látrány: Birkás-legelő, autós hálózás, késő délután, 2002. V. 4., Merkl O.

*Dignomus nitidus (Duftschmid, 1825) Látrány: Birkás-legelő, egyelés, 2001. IV. 13., Rozner Gy.; Látrány: Birkás-legelö, fenyves, talajcsapda, 2002. IV. 2-26., Rozner Gy.

Ptinomorphus imperialis (Linnacus, 1767) Látrány: Birkás-legelő, 2001. IV. 26., Rozner I.

*Ptinomorphus regalis (Duftschmid, 1825) Látrány: Birkás-legelö, 2001. IV. 26., Podlussány A. *Ptinus dubius Sturm, 1795 - Látrány: Birkás-lcgelö, 2001. IV. 26., Podlussány A.

*Ptinus fur (Linnaeus, 1758) - Látrány: Kollátilegelō, 2001. IV. 26., Rozner I.

*Xestobium plumbeum (Linnacus, 1785) Látrány: legelö, 1998. IV. 24., Rozner Gy.

*Xyletinus distinguendus Kofler, 1970 - Látrány:

Birkás-legelö, 2001. V. 13., Szalóki D.; Látrány: Birkás-legelö, (5. számú terület), fühálózás, 2002. V. 4., Merkl $\mathrm{O}$.

\section{Cleridae}

(meghatározta: Szalóki Dezső)

Clerus mutillarius Fabricius, 1775 - Látrány: Birkás-legelő (4. számú terület), 2002. IV. 26., Rozner I. 
Necrobia rufipes (De Gecr, 1775) - Látrány: Birkás-legelö (5. számú terület), kutyadögröl, 2001. VIl. 5., Merkl O.

Necrobia violacea (Linnacus, 1758) - Látrány: Birkás-legelő (5. számú terület), kutyadögröl, 2001. VII. 5., Merkl O.; Látrány: Birkás-legelö, 1999. III. 31., Rozner Gy.

\section{Melyridae}

(meghatározta: Szalóki Dezső)

Aplocnemus impressus (Marsham, 1802) Látrány: Birkás-legelő (5. számú terület), fühálózás, 2002. V. 4., Merkl O.

Celidus equestris (Fabricius, 1781) - Látrány: Birkás-legelő, autós hálózás, késő délután, 2002. V. 4., Merkl O. Szalóki (2001) Anthocomus bipunctatus (Harrer, 1784) néven említi Somogy megyéből.

Charopus concolor (Fabricius, 1801) - Látrány: Birkás-legelő (5. számú terület), fühálózva, 2001. IV. 29., Szalóki D.; Látrány, 2001. IV. 29., Szalóki D.; Látrány, 2001. V. 13., Szalóki D.; Látrány, 2001. V. 18., Szalóki D.

Clanoptilus ambiguus (Peyron,1877) - Látrány, 2001. V. 13., Szalóki D.

Dasytes aerosus Kiesenwetter, 1867 - Látrány: legelö, 1998. IV. 24., Rozner Gy.; Látrány, 2001. V. 13., Szalóki D.; Látrány: Nyíres-legelö, 2002. IV. 26., Podlussány A.; Látrány: Birkás-lcgelő, 2002. IV. 26., Podlussány A.; Látrány: Birkás-legelő, kopogtatás, 2002. IV. 26., Rozncr 1,; Látrány: Birkás-legelő (5. számú terülct), fühálózás, 2002. V. 4., Mcrkl O.

Dasytes fusculus (Illiger, 1801) - Látrány: Birkás-lcgclő (5. számú terület), fühálózva, 2001. IV. 29., Szalóki D.; Látrány: Nyíres-legelő, 2002. IV. 26., Podlussány A.; Látrány: Birkás-lcgelő, 2002. IV. 26., Podlussány A.

Dasytes plumbeus (O. F. Müller, 1776) - Látrány, fénycsapda, 2001. V1. 25., Ábrahám L.

Dolichosoma lineare (Rossi, 1792) - Látrány, 2001. V. 13., Szalóki D.; Látrány, 2001. V. 18. Szalóki D.; Látrány: Birkás-legelő, 2002. IV. 26., Podlussány A.; Látrány: Kolláti-legelő, 2002. IV. 26., Rozner I.

Hypebaeus flavipes (Fabricius, 1787) - Látrány: Birkás-lcgclö, 2001. IV. 26., Podlussány A.

Malachius bipustulatus (Linnaeus, 1758) Látrány: Birkás-legclö (5. számú terület), fühálózva, 2001. IV. 29., Szalóki D.; Látrány, 2001. V. 13., Szalóki D.; Látrány, 2001. V. 18., Szalóki D.; Látrány: Birkás-legelő (5. számú terület), fühálózás, 2002. V. 4., Merkl O.; Látrány: Nyíres-legelö, 2002. IV. 26., Podlussány A.; Látrány: Birkás-legelö, 2002. IV. 26., Podlussány A.

Nitidulidae

(meghatározta: Merkl Ottó)

*Carpophilus bipustulatus (Hcer, 1841) Látrány: Birkás-legelö, cscres, talajcsapda, 2002. IV. 2-26., Rozner Gy.
Cychramus luteus (Fabricius, 1787) - Látrány: Kolláti-legelö, 2001. X. 5., Rozner I.

Glischrochilus quadriguttatus (Fabricius, 1776)

- Látrány: Birkás-legelő, fenyves, talajcsapda, 2002.

III. 14.-IV. 2., Rozner Gy.

Glischrochilus quadrisignatus (Say, 1835) Látrány: Kolláti-legelő, talajcsapda, 1998. IV. 24-V. 15., Rozner Gy.; Látrány: Birkás-legelö, talajcsapda, 1999. IV. 1-14., Rozner Gy.; Látrány, 2001. IV. 29. Szalóki D.; Látrány: Birkás-legelö, cseres, talajcsapda, 2002. III. 14-IV. 2., Rozner Gy.; Látrány: Birkáslegelö (3. számú terület), talajcsapda, 2002. III. 14IV. 2., Rozner Gy.

*Glischrochilus quadripunctatus (Linnaeus, 1758) (1. ábra) - Látrány: Birkás-legelő, fenyves, talajcsapda, 2002. IV. 2-26., Rozner Gy. - A Palearktikus régió tajgazónájának és hegyvidéki fenyveseinek jellegzetes fénybogárfaja. A Kárpátokban elég gyakori, hazánkban azonban csak nyolc lelöhelyc ismert (2. ábra). Elöfordulási adatai: Bakonypölöske (XN 83), Köszeg (XN 15), Látrány (YM 08), Öriszentpéter (XM 08), Szalafő (XM 09), Szöce (XM 19), Telkibánya (EU 27), Zirc (YN 13).

*Meligethes discoideus Erichson, 1845. Látrány: Birkás-legelô, autós hálózás, késő délután, 2002. V. 4., Mcrkl O.

* Omosita depressa (Linnacus, 1758) - Látrány: Birkás-legelö, csercs, talajcsapda, 2002. III. 14-IV. 2., Rozner Gy.; Látrány: Birkás-legelö, fenyves, talajcsapda, 2002. IV. 2-26., Rozner Gy.

*Omosita discoidea (Fabricius, 1775) - Látrány: Birkás-legelő, (5. számú terület), kutyadögröl, 2002. V. 4., Merkl O.; Látrány: Birkás-legelö, 2002. IV. 26., Podlussány A.

*Soronia punctatissima (llliger, 1794) - Látrány: Kolláti-legelö, $46^{\circ} 44^{\prime} 07^{\prime \prime} \mathrm{N}, 17^{\circ} 46^{\prime} 20^{\prime \prime} \mathrm{E}$, (füzes), 2002. V1. 16., talajcsapda, Szinetár Cs.

*Thalycra fervida (Olivier, 1790) - Látrány: Birkás-legelö, 46²4 $04^{\prime \prime} \mathrm{N}, 17^{\circ} 45^{\prime} 50^{\prime \prime} \mathrm{E}$, (égeres), 2002. VI. 16., talajcsapda, Szinetár Cs.; Látrány: Birkás-legelö, $46^{\circ} 44^{\prime} 03^{\prime \prime} \mathrm{N}, 17^{\circ} 45^{\prime} 44^{\prime \prime} \mathrm{E}$, (fiatal tölgyes), 2002. VI. 16., talajcsapda, Szinetár Cs.

\section{Monotomidae}

(meghatározta: Merkl Ottó)

*Cyanostolus aeneus (Richter, 1820) - Látrány: Birkás-legelö, égeres, talajcsapda, 2001. VI. 17.-VII. 17., Rozner Gy. - Lomberdőkben és fenyvesekben elöforduló ritka faj, amclynck Magyarországon ez a hetedik lelöhelye. A további hat lelöhelyet lásd Merkl (1996).

*Monotoma longicollis (Gyllenhal, 1827) Látrány: Birkás-legelő, autós hálózás, késő délután, 2002. V. 4., Merkl O.

Rhizophagus bipustulatus (Fabricius, 1792) Látrány, 2001. Il. 23., Rozncr Gy.; Látrány: Birkáslcgelö, fenyves, talajcsapda, 2002. III. 14-IV. 2., Rozner Gy.; Látrány: Birkás-legclö, fenyves, talaj- 
csapda, 2002. IV. 2-26., Rozncr Gy.

*Rhizophagus perforatus Erichson, 1845 Látrány: Birkás-lcgelő, autós hálózás, késő délután, 2002. V. 4., Merkl O.

\section{Cucujidae}

(meghatározta: Merkl Ottó)

Pediacus dermestoides (Fabricius, 1792) Látrány: Birkás-lcgelö, fenyves, talajcsapda, 2002. III. 14-IV. 2., Rozner Gy.; Látrány: Birkás-legelö, cseres, talajesapda, 2002. IV. 2-26., Rozner Gy.

Silvanidae

(meghatározta: Merkl Ottó)

*Ahasverus advena (Waltl, 1832) - Látrány: Birkás-legelö, autós hálózás, késő délután, 2002. V. 4., Mcrkl O.

Psammoecus bipunctatus (Fabricius, 1792) Látrány: Birkás-lcgelő, autós hálózás, késő délután, 2002. V. 4., Merkı O.

\section{Erotylidae}

(meghatározta: Merkl Ottó)

Combocerus glaber (Schaller, 1783) - Látrány, 2001. IV. 12., Rozner Gy.; Látrány: Kolláti-legelö (1. számú terület), 2002. IV. 26., Podlussány A.

\section{Byturidae}

(meghatározta: Merkl Ottó)

Byturus ochraceus (L. G. Scriba, 1790) Látrány: Birkás-legclö, 2002. IV. 26., Podlussány A.; Látrány: Kolláti-legclö, 2002. IV. 26., Podlussány A.; Látrány: Birkás-legclő, (5. számú terület), fühálózás, 2002. V. 4., Merkl O.; Látrány: Nyíres-lcgelő, 2002. IV. 26., Podlussány A.

\section{Bothrideridae}

(meghatározta: Merkl Ottó)

Bothrideres contractus (Fabricius, 1792) Látrány: Kolláti-legelö, egyelés, 2002. IIl. 14., Rozner Gy.

\section{Cerylonidae}

(meghatározta: Merkl Ottó)

Cerylon histeroides (Fabricius, 1792) - Látrány: Birkás-legclő, cgyclés, 2001. IV. 18., Rozner I.; Látrány: Birkás-legclö, autós hálózás, késő délután, 2002. V. 4., Mcrkl O.

\section{Coccinellidae \\ (meghatározta: Merkl Ottó)}

Adalia bipunctata (Linnaeus, 1758) - Látrány, legelö, 1998. IV. 24., Rozner Gy.; Látrány: Kolláti-legclö (1. számú terület), 2001. Vll. 10., Kondorosy E.;
Látrány: Birkás-legelő (5. számú terület), 2002. V. 26., Rozner. I.; Látrány: Birkás-legelö, (5. számú terülct), fühálózás, 2001. VIl. 5., Merkl O.; Látrány (2. számú terület), 2001. VII. 10., Kondorosy E.; Látrány: Kolláti-legelő (1. számú terület), 2002. IV. 26., Rozner I.; Látrány: Birkás-legclő, (5. számú terület), fühálózás, 2002. V. 4., Mcrkl O.

Adalia decempunctata (Linnacus, 1758) Látrány, legelő, 1998. IV. 24., Rozner Gy.; Látrány, 2001. V. 16., Ábrahám L.; Látrány: Birkás-legelö, (5. számú tcrület), fühálózás, 2001. VII. 5., Merkl O.; Látrány: Kolláti-legelö (1. számú terület), 2002. IV. 26., Rozner I,; Látrány: Birkás-legelö, (5. számú terület), fühálózás, 2002. V. 4., Merkl O.

Anatis ocellata (Linnaeus, 1758) - Látrány: Birkás-legelö, 2001. IV. 26., Podlussány A.

Calvia quatuordecimguttata (Linnaeus, 1758) Látrány: Birkás-legelő, 2001. IV. 26., Podlussány A.; Látrány: Birkás-legelő, 2002. IV. 26., Podlussány A.; Látrány: Kolláti-legelő (1. számú terület), 2002. IV. 26., Rozner I.; Látrány: Birkás-legelő (5. számú terület), 2002. V. 26., Rozner. I.; Látrány: Kolláti-legelő (1. számú terület), fühálózás, 2001. VII. 5., Merkl O.; Látrány (2. számú terület), 2001. VII. 10. Kondorosy E.; Látrány: Birkás-legelö, (5. számú terület), fühálózás, 2002. V. 4., Merkl O.

Calvia quindecimguttata (Fabricius, 1777) Látrány, fénycsapda, 2001. VII. 5., Ábrahám L.; Látrány, fénycsapda, 2001. VI. 25., Ábrahám L.

Chilocorus bipustulatus (L. G. Scriba, 1791) Látrány: Birkás-legelő, 2002. IV. 26., Podlussány A.; Látrány: Nyíres-legelö, 2002. IV. 26., Podlussány A.; Látrány: Birkás-legelő (5. számú terület), 2002. V. 26., Rozner. I.; Látrány: Birkás-legelö, 2001. X. 5. , Podlussány A.

Chilocorus renipustulatus (Linnaeus, 1758) Látrány, Látránypuszta, Kolláti-legelö, 2001. X. 5., Podlussány A.; Látrány: Birkás-legelö, autós hálózás, késő délután, 2002. V. 4., Merkl O.

Coccidula rufa (Herbst, 1783) - Látrány, legelő, 1998. IV. 24., Rozner Gy.

Coccidula scutellata (Herbst, 1783) - Látrány: Birkás-legelö, (5. számú terülct), fühálózás, 2001. VII. 5., Mcrkl O.; Látrány: Kolláti-legelő, 2002. IV. 26., Podlussány A.; Látrảny: Birkás-legelő, autós hálózás, késő délután, 2002. V. 4., Mcrkl O.

Coccinella septempunctata Linnaeus, 1758 . Látrány, füháló, 1998. VI. 22., Rozner Gy.; Látrány: Kolláti-legelö, talajesapda, 1999. IV.1-14., Rozner Gy.; Látrány: Kolláti-legclő (1. számú terület), 2001. VII. 10., Kondorosy E;; Látrány: Birkás-legclő, 2002. IV. 26., Podlussány A.; Látrány: Kolláti-legelő, 2001. IV. 26., Rozner I.; Látrány (2. számú terület), 2001. VII. 10., Kondorosy E.; Látrány: Kolláti-legelő (1. számú terület), 2002. IV. 26., Rozner I.; Látrány: Nyires-legelö, 2002. V. 26., Rozner. I.

Coccinula quatuordecimpustulata (Linnacus, 1758) - Látrány: Birkás-legelő, 2001. IV. 26. Podlussány A.; Látrány, 2001. IV. 29., Szalóki D.; 
Látrány: Birkás-lcgelő, (5. számú terület), fühálózás, 2001. VII. 5., Mcrkl O.; Látrány (2. számú terület), 2001. VIl. 10., Kondorosy E.; Látrány: Kolláti-legelő (1. számú tcrület), 2002. VII. 19., Kondorosy E.

Cynegetis impunctata (Linnacus, 1758) Látrány, legelő, 1998. IV. 24., Rozner Gy.; Látrány: Birkás-legelô, fühálózás, 1999. IV. 14., Rozner Gy.; Látrány: Birkás-legelö, 2001. IV. 26., Podlussány A.; Látrány, 2001. IV. 29., Szalóki D.; Látrány: Birkáslegelö (5. számú terület), 2001. IV. 26., Rozner I.; Látrány (2. számú terület), 2001. VII. 10., Kondorosy E.; Látrány: Kolláti-legelő, 2002. IV. 26., Podlussány A.; Látrány: Nyíres-legelö, 2002. IV. 26., Podlussány A.; Látrány: Birkás-legelő, (5. számú tcrülct), fühálózás, 2002. V. 4., Mcrkl O.; Látrány: Nyires-legclö, 2002. V. 26., Rozner. I.; Látrány: Látrányi-puszta, fühálózás, 2002. VI. 30., Merkl O.

Exochomus quadripustulatus (Linnacus, 1758) Látrány: Birkás-legelö, 2001. IV. 26., Podlussány A.; Látrány: Kolláti-legelö (1. számú terület), 2001. VII. 10., Kondorosy E.; Látrány: Kolláti-legelő, 2001. X. 5., Rozner I.

Harmonia quadripunctata (Pontoppidan, 1763) Látrány, fénycsapda, 2001. VIl. 1., Ábrahám L.; Látrány: Nyircs-lcgclö, 2002. IV. 26., Podlussány A.

Hippodamia (Adonia) variegata (Gocze, 1777) Látrány, füháló, 1998. VIII. 22., Rozner Gy.; Látrány: Kolláti-legelö, 2001. IV. 26., Rozner I.; Látrány: Kolláti-legelö, (1. számú terület), fühálózás, 2001. VII. 5., Merkl O.; Látrány: Kolláti-legclő (1. számú terület), 2001. VIl. 10., Kondorosy E.; Látrány, 2001. VII. 31., Szalóki D.; Látrány: Birkás-legelő, 2002. IV. 26., Podlussány A.; Látrány: Birkás-legelổ (5. számú terület), 2002. IV. 26., Rozner I.; Látrány: Kolláti-legelő (1. számú terület), 2002. IV. 26., Rozner I.; Látrány: Nyíres-legclö, 2002. IV. 26., Podlussány A.; Látrány: Nyíres-legelő, 2002. V. 26., Rozner. 1.

Hippodamia (Hippodamia) tredecimpunctata (Linnacus, 1758) - Látrány, legelö, 1998. IV. 24., Rozncr Gy.; Látrány: Kolláti-legelő, 2001. IV. 26., Rozner I.; Látrány: Birkás-legclő, 2002. IV. 26., Podlussány A.; Látrány: Birkás-legelö, (5. számú terület), fühálózás, 2001. VII. 5., Merkl O.

Hippodamia (Semiadalia) undecimnotata (Schncider, 1792) - Látrány: Kolláti-lcgclő, (1. számú tcrülct), fühálózás, 2001. VII. 5., Merkl O.; Látrány: Kolláti-legelő, 2001. IV. 26., Rozner I.; y, 2001. VII. 31., Szalóki D.; Látrány: Birkás-legelő, (5. számú terület), fühálózás, 2002. V. 4., Merkl O.

Myrrha octodecimguttata (Linnacus, 1758) Látrány, fénycsapda, 2001. VI. 25., Ábrahám L.

Nephus redtenbacheri Mulsant, 1846 - Látrány: Birkás-legelö, 2002. IV. 26., Podlussány A.

Oenopia conglobata (Linnaeus, 1758) - Látrány: Birkás-legelő, 2001. IV. 26., Podlussány A.; Látrány (2. számú terület), 2001. VII. 10., Kondorosy E.; Látrány: Birkás-legclő (5. számú terület), 2002. V. 26., Rozner. 1.
Oenopia lyncea agnata (Rosenhauer, 1847) Látrány: Birkás-legelö, 2001. IV. 26., Podlussány A. Oenopia conglobata (Linnaeus, 1758) - Látrány, 2001. V. 16., Ábrahám L.

Platynaspis luteorubra (Gocze, 1777) - Látrány: Birkás-legelő, 2000. VI. 4., Rozner I.; Látrány: Kolláti-legelő (1. számú terület), 2002. IV. 26., Rozner I.

Propylea quatuordecimpunctata (Linnaeus, 1758) - Látrány, legelö, 1998. IV. 24., Rozner Gy.; Látrány: Birkás-legelő, 2001. IV. 26., Podlussány A.; Látrány: Kolláti-legelö (1. számú terület), 2001. VII. 10., Kondorosy E.; Látrány: Nyíres-legelö, 2002. IV. 26., Podlussány A.; Látrány: Birkás-legelő (5. számú terület), 2001. IV. 26., Rozner I.; Látrány, 2001. VII. 2., Rozner Gy; Látrány (6. számú terület), 2001. VII. 3., Rozner Gy.; Látrány (2. számú terület), 2001. VII. 10., Kondorosy E.; Látrány: Birkás-legelő, (5. számú terület), fühálózás, 2002. V. 4., Merkl O.; Látrány: Nyíres-legelö, 2002. V. 26., Rozner. I.

Psyllobora vigintiduopunctata (Linnacus, 1758) - Látrány, 2001. VII. 23., Ábrahám L.; Látrány: Kolláti-legelö (1. számú terület), 2001. VII. 10., Kondorosy E.; Látrány, 2001. VII. 31., Szalóki D.; Látrány: Birkás-legelő, 2002. IV. 26., Podlussány A.; Látrány: Birkás-legelő (5. számú terület), 2002. V. 26., Rozner. I.; Látrány: Kolláti-legelő, 2002. IV. 26., Podlussány A; Látrány: Kolláti-legelő (1. számú terület), 2002. VII. 19., Kondorosy E.

Rhyzobius chrysomeloides (Herbst, 1792) Látrány: Birkás-legelő, 2001. IV. 26., Podlussány A.; Látrány: Birkás-legelö, (5. számú terület), fühálózás, 2002. V. 4., Merkl O.

*Rhyzobius litura (Fabricius, 1787) - Látrány: Kolláti-legelö, 2001. X. 5., Rozner I.

Scymnus (Pullus) auritus Thunberg, 1795 . Látrány: Birkás-lcgelö, 2001. IV. 26., Podlussány A. Scymnus (Pullus) ferrugatus (Moll, 1785) Látrány: Kolláti-legelő (1. számú terület), fühálózás, 2001. VII. 5., Merkl O.

Scymnus (Pullus) suturalis (Thunberg, 1795) Látrány: Birkás-legelő, 2001. IV. 26., Podlussány A.; Látrány: Nyires-legelö, 2002. IV. 26., Podlussány A.; Látrány: Kolláti-legelö, fühálózás, 2001. VII. 5., Merkl O.

Scymnus (Scymnus) frontalis (Fabricius, 1787) Látrány, füháló, 1998. VI. 22., Rozner Gy.; Látrány: Birkás-legelő, 2001. IV. 26., Podlussány A.; Látrány: Kolláti-legelő, (1. számú terület), fühálózás, 2001. VII. 5., Merkl O.; Látrány: Birkás-legelő, (5. számú terület), fühálózás, 2001. VII. 5., Mcrkl O.; Látrány: Kolláti-legelő (1. számú terület), 2001. VII. 10., Kondorosy E.; Látrány: Birkás-legelö, 2002. IV. 26., Podlussány A.; Látrány: Kolláti-legelö, 2002. IV. 26., Podlussány A.; Látrány: Kolláti-legelő (1. számú terület), 2002. IV. 26., Rozner I.; Látrány: Nyíres-legelő, 2002. IV. 26., Podlussány A.; Látrány: Birkás-legelő, (5. számú terület), fühálózás, 2002. V. 4., Mcrkl O.; Látrány: Kolláti-legelö, 2001. IV. 26., Rozner 1. 
Scymnus (Scymnus) pallipediformis Günther, 1958 - Látrány: Kolláti-legelő, 2001. IV. 26., Rozner 1.; Látrány: Birkás-lcgelő, (5. számú tcrület), fühálózás, 2001. VII. 5., Merkl O.; Látrány: Kolláti-legclő, (1. számú terület), fühálózás, 2001. VII. 5., Merkl O..

Scymnus (Scymnus) rubromaculatus (Goeze, 1777) - Látrány: Birkás-legelő, 2002. IV. 26., Podlussány A.; Látrány: Nyíres-legelő, 2002. IV. 26., Podlussány A.; Látrány: Birkás-legelö, autós hálózás, késő délután, 2002. V. 4., Merkl O.

Sospita vigintiguttata (Linnaeus, 1758) Lảtrány: Birkảs-lcgelő, cgyelés, 2001. IV. 13., leg. Rozner Gy.

Stethorus punctillum Weise, 1891 - Látrány: Kolláti-legelő (1. számú terület), 2002. VII. 19., Kondorosy E.

Subcoccinella vigintiquatuorpunctata (Linnaeus, 1758) - Látrány, füháló, 1998. VIIl. 22., Rozner Gy.; Látrány, 2001. VII. 2., Rozner Gy; Látrány: Birkáslegclö, 2002. IV. 26., Podlussány A.; Látrány: Nyíreslegelö, 2002. IV. 26., Podlussány A.; Látrány, 2002. III. 28., Kondorosy E.; Látrány: Kolláti-legelö (1. számú terület), 2002. VII. 19., Kondorosy E.

Tytthaspis sedecimpunctata (Linnaeus, 1758) Látrány, legelö, 1998. IV. 24., Rozncr Gy.; Látrány, füháló, 1998. VIIl. 22., Rozner Gy.; Látrány: Birkáslegelö, 2001. IV. 26., Podlussány A.; Látrány, 2001. IV. 29., Szalóki D.; Látrány, 2001. V. 18., Szalóki D.; Látrány: Birkás-legclö, (5. számú terület), fühálózás, 2002. V. 4., Merkl O.; Látrány: Nyíres-legelő, 2002. V. 26., Rozner. I.

Vibidia duodecimguttata (Linnacus, 1758) Látrány: Kolláti-legelö, 2001. X. 5., Rozner 1.

\section{Mycetophagidae}

(meghatározta: Merkl Ottó)

*Litargus balteatus LeConte, 1856 - Látrány: Birkás-legelö, autós hálózás, késő délután, 2002 . V. 4., Merkl O.

Mycetophagus quadripustulatus (Linnacus, 1767) - Látrány: Birkás-legelö, 2000. V. 13., Rozner Gy.

\section{Ciidae}

\section{(meghatározta: Merkl Ottó)}

${ }^{*}$ Cis fissicollis Mellié, 1848 - Látrány: Birkás-legclő, autós hálózás, késő délután, 2002. V. 4., Merkl O.

*Orthocis lucasi (Abcille, 1874) - Látrány: Birkás-legelö, autós hálózás, kćső délután, 2002. V. 4., Merkl O.

* Sulcacis affinis (Gyllenhal, 1827) - Látrány: Birkás-legelö, cseres, talajcsapda, 2002. IV. 2-26., Rozner Gy.

\section{Melandryidae \\ (meghatározta: Szalóki Dezső)}

* Melandrya dubia (Schaller, 1783) - Látrány: Birkás-legelö, 2002. V. 7., Rozner Gy.
Osphya bipunctata (Fabricius, 1775) - Látrány: Kolláti-legelő, 2000. IV. 29., Rozner I.; Látrány: Birkás-legelő, 2002. IV. 16., kopogtatva, Podlussány A.; Látrány: Birkás-legelő (5. számú terület), fühálózás, 2002. V. 4., Merkl O.

\section{Zopheridae}

(meghatározta: Szalóki Dezső)

Bitoma crenata (Fabricius, 1775) - Látrány, fühálózás, 1998. VIII. 22., Rozner Gy.

*Colydium elongatum Fabricius, 1792 - Látrány: Kolláti-legelö, 2002. III. 14., Rozner Gy.

\section{Tenebrionidae}

(meghatározta: Szalóki Dezső)

Alphitophagus bifasciatus (Say, 1823) - Látrány: Birkás-lcgelő, autós hálózás, késő délután, 2002. V. 4., Merkl O.

Crypticus quisquilius (Linnacus, 1761) Látrány: Kolláti-legelő (1. számú terület), fühálózás, 2001. VIl. 5., Merkl O.; Látrány: Birkás-legelö, 46 44'06"N-017 46'07"E (homokdomb K-i oldalán), talajcsapda, 2002. VI. 16., Szinetár Cs.; Látrány: Birkás-lcgclö, 46 43'56"N-017 45'57"E (homokdombon), talajcsapda, 2002. VI. 16., Szinetár Cs.

Cteniopus sulphureus (Linnacus, 1758) Látrány: Birkás-legelö, 2001. VI. 26., Rozner I.; Látrány: Birkás-legelö (5. számú terület), fühálózás, 2001. VII. 5., Merkl O.; Látrány, fühálózás, 1998. VI. 22., Rozner Gy.; Látrány (6. számú terület), 2001. VII. 3., Rozner Gy.; Látrány (2. számú terület), 2001. VII. 10., Kondorosy E.

Gonodera luperus (Herbst, 1783) - Látrány: Birkás-legelö (5. számú terület), fühálózás, 2002. V. 4., Merkl O.; Látrány: Birkás-legelö, 2001. IV. 26., Podlussány A.; Látrány: Birkás-legelö, 2002. IV. 26., Podlussány A.; Látrány: Birkás-legelö, kopogtatás, 2002. IV. 26., Rozner I.

Hymenalia rufipes (Fabricius, 1792) - Látrány, 1999. VII. 16., Ábrahám L.; Látrány: Kolláti-lcgclő (1. számú terület), fühálózás, 2001. VII. 5., Merkl O.; Látrány: Kolláti-legelő (1. számú terület), 2001. VII. 10., Kondorosy E.

Isomira antennata (Panzer, 1798) - Látrány: Birkás-legelő, 2000. V. 13., Rozner Gy.; Látrány: Kolláti-legelö, 2002. IV. 26., Rozner I.

Isomira murina (Linnacus, 1758) - Látrány, 2001. V. 18., Szalóki D.

Lagria hirta (Linnaeus, 1758) - Látrány (2. számú terület), 2001. VII. 10., Kondorosy E.; Látrány: Kolláti-legelö (1. számú terület), 2002. VII. 19., Kondorosy E.

Melanimon tibiale (Fabricius, 1781) - Látrány: Kolláti-legclö, 2000. IV. 11., Rozner Gy.; Látrány, 2002. III. 28., Kondorosy E.; Látrány: Kolláti-legelő, 2002. IV. 26., Podlussány A.; Látrány: Nyíres-legelö, 2002. IV. 26., Podlussány A. 
*Myrmechixenus vaporariorum GuérinMéneville, 1843 - Látrány: Birkás-legelő, autós hálózás, késő délután, 2002. V. 4., Merkl O.

Nalassus dermestoides (Illiger, 1798) - Látrány:

Kolláti-legelö, 2002. IV. 26., Rozner I.

Omophlus lividipes Mulsant, 1856 - Látrány,

2001. V. 18., Szalóki D.

Opatrum sabulosum (Linnaeus, 1761) - Látrány, 2001. IV. 12., Szalóki D.; Látrány, 2002. III. 28., Kondorosy $\mathrm{E}$.

*Pedinus femoralis (Linnaeus, 1767) - Látrány, 2001. IV. 12., Szalóki D.; Látrány: Birkás-legelö, 46 44'06"N-017 46'07"E (homokdomb K-i oldalán), talajcsapda, 2002. Vl. 16., Szinetár Cs.; Látrány: Birkás-legclö, 46 43'56"N-017 45'57"E (homokdombon), talajcsapda, 2002. V1. 16., Szinetár Cs.

Scaphidema metallicum (Fabricius, 1792) Látrány: Birkás-legelő (5. számú terület), fühálózás, 2002. V. 4., Merkl O.; Látrány: Birkás-legelő, akácos, talajcsapda, 2002. III. 4-IV.2., Rozner Gy.

Stenomax aeneus (Scopoli, 1863) - Látrány: Birkás-legelő, 2001. IV. 25.

\section{Oedemeridae}

(meghatározta: Szalóki Dezső)

Chrysanthia viridissima (Linnaeus, 1758) Látrány (2. számú terület), 2001. VII. 10., Kondorosy E.

Nacerdes carniolica (Gistl, 1832) - Látrány: Birkás-legelő (5. számú terület), fühálózás, 2001. VII. 5., Merkl O.

Oedemera croceicollis Gyllenhall, 1827 Látrány: Birkás-legelő (5. számú tcrület), fühálózás, 2002. V. 4., Mcrkl O.; Látrány, 2001. VII. 2,, Rozner Gy. Oedemera femorata (Scopoli, 1763) - Látrány: Kolláti-legelő (1. számú terület), 2001. VII. 5., fühálózás, Mcrkl O.; Látrány, 2001. VII. 31., Szalóki D.

Oedemera flavipes (Fabricius, 1792) - Látrány, 2001. V. 18., Szalóki D.; Látrány (2. számú terület), 2001. VII. 10., Kondorosy E.

Oedemera lurida (Marsham, 1802)- Látrány: Birkás-legelő (5. számủ terület), 2001. VII. 5., fühálózás, Merkl O.; Látrány, 2001. V. 13., Szalóki D.; Látrány, 2001. V. 18., Szalóki D.

Oedemera podagrariae (Linnacus, 1767) Látrány, 1998. VI. 22., Rozner Gy.; Látrány, 2001. VII. 31., Szalóki D.

Oedemera virescens (Linnacus, 1767) - Látrány: Birkás-legelő (5. számú terület), fühálózás, 2002. V. 4., Merkl O.; Látrány, 2001. IV. 29., Szalóki D.; Látrány: Birkás-legelö, 2001. IV. 13., Rozner Gy.; Látrány: Nyíres-legelö, 2002. IV. 26., Podlussány A.; Látrány: Birkás-legelö, 2002. IV. 26, Podlussány A.; Látrány: Kolláti-legelő, 2002. IV. 26., Rozner I.; Látrány: Nyíres-legclö, 2002. IV. 26., Rozner I.; Látrány: Birkás-legelő, 2002. IV. 26., Rozner I.

\section{Meloidae}

(meghatározta: Szalóki Dezső)

Cerocoma schreberi Fabricius, 1781 - Látrány: Birkás-legelő, 2001. VI. 26., Rozner I.; Látrány, 2001. VIl. 3., Rozner Gy.; Látrány: Birkás-legelő (5. számú tcrület), 2001. VII. 5., fühálózás, Merkl O.; Látrány: Látrányi puszta, 2001. VII. 4., virágokról, Merkl O.; Látrány (6. számú terület), 2001. VII. 3., Rozner Gy.

Meloe proscarabaeus Linnaeus, 1758 - Látrány: Kolláti-legelö, 2002. III. 14., Rozner Gy.

Zonitis praeusta Fabricius, 1792 - Látrány: Kolláti-legelö, 2001. VII. 31., Daucus carota, Szalóki D.; Látrány: Birkás-legelö, Daucus carota, 2001. VII. 31., Szalóki D.; Látrány: Látrányi-puszta, virágokról, 2001. VII. 4., Merkl O.

\section{Pythidae}

(meghatározta: Szalóki Dezső)

Pytho depressus (Linnacus, 1767) - Látrány: Birkás-legelö, 2002. III. 4., Rozner Gy.

\section{Pyrochroidae}

(meghatározta: Szalóki Dezső)

Pyrochroa coccinea (Linnaeus, 1761) - Látrány, 2001. V. 13., Szalóki D.; Látrány: Birkás-legelö, 2001. IV. 26., Podlussány A.; Látrány: Birkás-legelö, 2002. IV. 26., Podlussány A.

Pyrochroa serraticornis (Scopoli, 1763) Látrány: Birkás-legelö, 2002. IV. 26., Podlussány A.; Látrány (5. számú terület), Birkás-legelö, 2002. IV. 26., Rozner I.; Látrány: Tetves-patak, 2002. IV. 26., Rozner I.

\section{Salpingidae}

(meghatározta: Szalóki Dezső)

Salpingus planirostris (Fabricius, 1787) Látrány: Birkás-legelő, autós hálózás, késő délután, 2002. V. 4., Merkl O.

Vincenzellus ruficollis (Panzer, 1794) - Látrány: Duda-tető, 1998. IIl. 30-31., Rozner Gy.

\section{Anthicidae}

(meghatározta: Szalóki Dezső)

Notoxus monoceros (Linnaeus, 1761) - Látrány: legelö, 98. IV. 24., Rozner Gy.; Látrány: Birkás-legelö, 2001. IV. 26., Podlussány A.; Látrány: Birkás-legelő, autós hálózás, kćső délután, 2002. V. 4., Merk1 O.; Látrány: Birkás-legclö, 2002. IV. 26., Podlussány A.; Látrány: Nyíres-lcgelő, 2002. IV. 26., Rozner I.

Omonadus floralis (Linnaeus, 1758) - Látrány: Duda-tctő, 1998. III. 30-31., Rozner Gy.; Látrány: Birkás-lcgelő, autós hálózás, kćső délután, 2002. V. 4., Mcrkl O.; Lảtrány: Birkás-legelő, 2001. X. 5., Rozner I. 
Omonadus formicarius (Gocze, 1777) - Látrány: Duda-tető, 1998. 11I. 30-31., Rozner Gy.

\section{Aderidae}

(meghatározta: Szalóki Dezső)

Vanonus pruinosus (Kiesenwetter, 1861) Látrány: Birkás-legelő, 2001. IV. 26., Podlussány A.; Látrány: Birkás-legelő, autós hálózás, késő délután, 2002. V. 4., Merkl O.

\section{Nemonychidae}

(meghatározta: Podlussány Attila)

Cimberis attelaboides (Fabricius, 1787) Látrány: Birkás-legelő, 2000. IV. 20., Rozner Gy; Látrány: Birkás-legclö, kopogtatás, 2001. IV. 26., Podlussány A., Rozncr 1., Rozner Gy.; Látrány: Kolláti-legelö (1. számú terület), kopogtatás, 2002. IV. 26., Podlussány A., Rozner I., Rozner Gy.; Látrány: Birkás-lcgelö (4. számú terület), kopogtatás, 2002. IV. 26., Podlussány A., Rozner I., Rozner Gy.

\section{Anthribidae}

(meghatározta: Podlussány Attila)

Anthribus albinus (Linné, 1758) - Látrány: Kolláti-legelö, $46^{\circ} 44^{\prime} 07^{\prime \prime}$ É, $017^{\circ} 46^{\prime} 20^{\prime \prime} \mathrm{K}, 131 \mathrm{~m}$ talajcsapda, 2002. VI. 16., Szinetár Cs.

Brachytarsus nebulosus (Forster, 1771) Látrány: Birkás-legelö, fühálózás; 2001. IV. 26., Podlussány A., Rozner I., Rozner Gy.

Dissoleucas niveirostris (Fabricius, 1798) Látrány: Birkás-legelö, rostálás, 2001. X. 5., Podlussány A., Rozner I., Rozner Gy.

Rhaphitropis marchicus (Herbst, 1797) Látrány: Birkás-legelö, kopogtatás, 2000. VI. 4., Podlussány A., Rozner I., Rozner Gy.; Látrány: Birkás-legelö (4. számú terület), rostálás, 2002. IV. 26., Podlussány A., Rozner l., Rozner Gy.; Látrány: Birkás-legelö, 2001. VI. 14., Rozner Gy.

*Urodon schusteri Schilsky, 1912 - Látrány: Birkás-legelö, fühálózás, 2000. VI. 4., Podlussány A., Rozner I., Rozner Gy.

\section{Rhynchitidae}

(meghatározta: Podlussány Attila)

Byctiscus populi (Linné, 1758) - Látrány: Kolláti-legelö, 2000. V. 13., Kondorosy E., Rozner Gy.

Deporaus betulae (Linné, 1758) - Látrány: Kolláti-legelö, 2000. V. 13., Kondorosy E., Rozner Gy,; Látrány: Birkás-legelő (4. számú terület), kopogtatás, 2002. IV. 26., Podlussány A., Rozner I., Rozner Gy.

Involvulus caeruleus (De Geer, 1775) - Látrány: Birkás-legelö, 2000. IV. 20., Rozner Gy; Látrány, 2001. IV. 24., Rozner Gy.; Látrány: Kolláti-legelő, 2001. IV. 25., Rozncr Gy.; Látrány: Birkás-legelö, fü- hálózás, 2001. IV. 26., Podlussány A., Rozner I., Rozner Gy.; Látrány: Birkás-legelő (4. számú terület), kopogtatás, 2002. IV. 26., Podlussány A., Rozner I., Rozner Gy.

Neocoenorrhinus aeneovirens (Marsham, 1802) - Látrány: Kolláti-legelő, 2001. IV. 25., Rozner Gy.; Látrány: Birkás-legelö, kopogtatás, 2001. IV. 26., Podlussány A., Rozner I., Rozner Gy.; Látrány: Kolláti-legelő (1. számú terület), kopogtatás, 2002. IV. 26., Podlussány A., Rozner 1., Rozner Gy.; Látrány: Birkás-legelö (4. számú terület), kopogtatás, 2002. IV. 26., Podlussány A., Rozner I., Rozner Gy.; Látrány: Birkás-legelő (5. számú terület), fühálózás, 2002. V. 4., Merkl O.

Neocoenorrhinus aequatus (Linné, 1767) Látrány: Kolláti-legclő, fühálózás, 2000. IV. 29., Rozner I.; Látrány: Kolláti-legelő, 2000. V. 13., Kondorosy E., Rozner Gy.; Látrány, 2001. IV. 24., Rozner Gy.; Látrány: Kolláti-legelő, kopogtatás, 2001. IV. 26., Podlussány A., Rozner I., Rozner Gy.; Látrány: Birkás-legelö, kopogtatás, 2001. IV. 26., Podlussány A., Rozner I., Rozner Gy.; Látrány: Kolláti-legelő (1. számú terület), kopogtatás, 2002. IV. 26., Podlussány A., Rozner I., Rozner Gy.; Látrány: Birkás-legelő (4. számú terület), kopogtatás, 2002. IV. 26., Podlussány A., Rozner I., Rozner Gy.; Látrány: Birkás-legelö (5. számú terület), fühálózás, 2002. V. 4., Merkl O.; Látrány, talajcsapda, 1998. IV. 24.-V. 15., Rozner Gy.

Neocoenorrhinus interpunctatus (Stephens, 1831) - Látrány: Birkás-legelö, Tetves-patak, 2001. IV. 25., Rozner Gy.

Neocoenorrhinus germanicus (Herbst, 1797) Látrány: Birkás-legelö, 2000. IV. 20., Rozner Gy.; Látrány: Birkás-legelő, fühálózás, 2001. IV. 26., Podlussány A., Rozner I., Rozner Gy.; Látrány: Kolláti-legelö (1. számú tcrület), fühálózás, 2002. IV. 26., Podlussány A., Rozner l., Rozner Gy.; Látrány: Birkás-legelő (4. számú terület), fühálózás, 2002. IV 26., Podlussány A., Rozner L., Rozner Gy.; Látrány, 1998. VI. 22., Rozner Gy.

Neocoenorrhinus pauxillus (Germar; 1824) Látrány: Birkás-legelő, 2000. IV. 20., Rozner Gy.; Látrány, 2000. V. 13., Kondorosy E.; Látrány: Kolláti-legclö, 2000. V. 13., Kondorosy E., Rozner Gy.; Látrány, 2001. IV. 24., Rozner Gy.; Látrány: Kolláti-legelö, kopogtatás, 2001. IV. 26., Podlussány A., Rozner I., Rozner Gy.; Látrány: Kolláti-legelö (1. számú terület), kopogtatás, 2002. IV. 26., Podlussány A., Rozner I., Rozner Gy.; Látrány: Birkás-legelö (4. számú terület), kopogtatás, 2002. IV. 26., Podlussány

A., Rozner 1., Rozner Gy.

Pselaphorhynchites tomentosus (Gyllenhal, 1839) - Látrány: Birkás-legelö, 2001. VI. 14., Rozner Gy. Rhynchites bacchus (Linnć, 1758) - Látrány: Birkás-legclö, kopogtatás, 2001. X. 5., Podlussány A., Rozner 1., Rozner Gy.

*Rhynchites cupreus (Linné, 1758) - Látrány: Birkás-legelő, kopogtatás, 2001. IV. 26., Podlussány A. 
Attelabidae

(meghatározta: Podlussány Attila)

Attelabus nitens (Scopoli, 1763) - Látrány: Kolláti-legelő, 2001. IV. 25., Rozner Gy.

\section{Apionidae}

(meghatározta: Podlussány Attila)

Acanephodus onopordi (Kirby, 1808) - Látrány: Kolláti-legelő, 2001. IV. 25., Rozner Gy.; Látrány: Kolláti-legelő, fühálózás, 2001. IV. 26., Podlussảny A., Rozner I., Rozner Gy.; Látrány: Birkás-legelő, fühálózás, 2001. IV. 26., Podlussány A., Rozner I., Rozner Gy.; Látrány: Birkás-legelő, fühálózás, 2001. X. 5., Podlussány A., Rozner I., Rozner Gy.; Látrány: Kolláti-legelő (1. számú terület), fühálózás, 2002. IV. 26., Podlussány A., Rozner I., Rozner Gy.; Látrány: Birkás-legelö (4. számú terület), fühálózás, 2002. IV. 26., Podlussány A., Rozner l., Rozner Gy.; Látrány: Nyires-legelő, fühálózás, 2002. IV. 26., Podlussány A., Rozner I., Rozner Gy.; Látrány: Birkás-legelö, Tetves-patak, 2001. IV. 25., Rozner Gy.

Apion cruentatum Walton, 1844 - Látrány: Birkás-legelö, fühálózás, 2001. IV. 26., Podlussány A., Rozner I., Rozner Gy.; Látrány: Birkás-legelő, 2001. VI. 14., Rozner Gy.

Apion frumentarium (Linné, 1758) - Látrány: Birkás-legelö, fühálózás, 2001. IV. 26., Podlussány A., Rozner I., Rozner Gy.; Látrány: Kolláti-legelö, fühálózás, 2001. X. 5., Podlussány A., Rozner I., Rozner Gy.; Látrány: Kolláti-legelő (1. számú terület), fühálózás, 2002. IV. 26., Podlussány A., Rozner I., Rozner Gy.; Látrány: Birkás-legelő (4. számú terület), fühálózás, 2002. IV. 26., Podlussány A., Rozner I., Rozner Gy.

Apion haematodes Kirby, 1808 - Látrány: Birkás-legelö, fühálózás, 2000. VI. 4., Podlussány A., Rozner I., Rozner Gy.; Látrány: Kolláti-legelő, fühálózás, 2000. VI. 4., Podluissány A., Rozner I., Rozner Gy. Aspidapion aeneum (Fabricius, 1775) - Látrány: Birkás-legelö (4. számú terület), fühálózás, 2002. IV. 26., Podlussány A., Rozner I., Rozner Gy.

Aspidapion validum (Germar, 1817) - Látrány: Birkás-legelő, fühálózás, 2001. X. 5., Podlussány A., Rozner I., Rozner Gy.

Catapion jaffense (Desbrochers des Loges, 1895) - Látrány: Kolláti-legelö, fühálózás, 2000. IV. 29., Rozner I.; Látrány: Kolláti-legclő, fühálózás, 2001. IV. 26., Podlussány A., Rozner I., Rozner Gy.; Látrány: Kolláti-legclő, 2001. VI. 16., Rozner Gy.; Látrány: Birkás-legclő, fühálózás, 2001. X. 5., Podlussány A., Rozner 1., Rozner Gy.; Látrány: Kolláti-legclö, fühálózás, 2001. X. 5., Podlussány A., Rozner 1., Rozner Gy.; Látrány: Kolláti-legelő, fühálózás, 2000. VI. 4., Podlussány A., Rozner I., Rozner Gy.; Látrány (1. számú terület), 2001. VII. 10., Kondorosy E.; Látrány: Látránypuszta, fưhálózás, 1998. VI. 27-28., Rozner I.
Catapion seniculus (Kirby, 1808) - Látrány: Kolláti-legelő, 2000. IV. 11., Rozner Gy.; Látrány: Birkás-legelô, fühálózás, 2001. IV. 26., Podlussány A., Rozner I., Rozner Gy.; Látrány: "dél", 2001. VIII. 24., Kondorosy E.; Látrány: Birkás-legelö, fühálózás, 2001. X. 5., Podlussány A., Rozner I., Rozner Gy.

*Ceratapion armatum (Gerstäcker, 1854) Látrány: Birkás-legelő, fühálózás, 2001. X. 5., Podlussány A., Rozner I., Rozner Gy.; Látrány: Kolláti-legelő, fühálózás, 2001. X. 5., Podlussány A., Rozner I., Rozner Gy.

*Ceratapion austriacum (Wagner, 1904) Látrány: Birkás-legelő, fühálózás, 2001. IV. 26., Podlussány A., Rozner I., Rozner Gy; Látrány: Kolláti-legelő, fühálózás, 2001. X. 5., Podlussány A., Rozner I., Rozner Gy.

Ceratapion gibbirostre (Gyllenhal, 1813) Látrány: Birkás-legelő, fühálózás, 2000. VI. 4., Podlussány A., Rozner I., Rozner Gy.; Látrány: Birkás-legelö, fühálózás, 2001. IV. 26., Podlussány A., Rozner I., Rozner Gy.; Látrány: Birkás-legelő, fühálózás, 2001. X. 5., Podlussány A., Rozner I., Rozner Gy.; Látrány: Kolláti-legelő, 1999. VII. 12., Rozner Gy.

Ceratapion penetrans (Germar, 1817) - Látrány: Kolláti-legelő, 2001. Vl. 16., Rozner Gy.; Látrány: "dél", 2001. VIll. 24., Kondorosy E.; Látrány: Birkás-legelō, fühálózás, 2001. X. 5., Podlussány A., Rozner I., Rozner Gy.; Látrány: Kolláti-legelő, fühálózás, 2001. X. 5., Podlussány A., Rozner I., Rozner Gy.; Látrány: Birkás-legelö (4. számú terület), fühálózás, 2002. IV. 26., Podlussány A., Rozner I., Rozner Gy.; Látrány: Kolláti-legelö, 1999. VII. 12., Rozner Gy.; Látrány: Látránypuszta, fühálózás, 2002. VI. 30., Merkl O.

Cyanapion columbinum (Germar, 1817) Látrány: Birkás-legelő, fühálózás, 2001. IV. 26., Podlussány A., Rozner I., Rozner Gy.; Látrány: Birkás-legelő, fühálózás, 2001. VI. 26., Rozner 1.; Látrány: Birkás-legelö, fühálózás, 2001. X. 5., Podlussány A., Rozner I., Rozner Gy.; Látrány: Kolláti-legelö, fühálózás, 2001. X. 5., Podlussány A., Rozner l., Rozner Gy.; Látrány: Kolláti-legelö, fühálózás, 2000. VI. 4., Podlussány A., Rozner 1., Rozner Gy.

Diplapion confluens (Kirby, 1808) - Látrány: Kolláti-legelö, 2001. Vl. 16., Rozner Gy.; Látrány: Birkás-legclő, fühálózás, 2001. X. 5., Podlussány A., Rozner I., Rozner Gy.; Látrány: Kolláti-legelö, fühálózás, 2001. X. 5., Podlussány A., Rozner I., Rozner Gy.

Diplapion detritum (Mulsant \& Rey, 1859) Látrány: Kolláti-legelö, 2000. VI. 3., Rozner I.; Látrány: Birkás-legelő, fühálózás, 2000. V1. 4., Podlussány A., Rozner I., Rozner Gy.; Látrány: Birkás-legclö, fühálózás, 2001. IV. 26., Podlussány A., Rozner I., Rozner Gy.; Látrány: Kolláti-legelő, fühálózás, 2000. VI. 4., Podlussány A., Rozner 1., Rozner Gy.

Diplapion stolidum (Germar, 1817) - Látrány: Kolláti-legelō, 2000. VI. 3., Rozner I.; Látrány: Birkás-lcgelő, fühálózás, 2001. IV. 26., Podlussány A., Rozner I., Rozner Gy.; Látrány: Birkás-legelő, fühá- 
lózás, 2001. X. 5., Podlussány A., Rozner I., Rozner Gy.; Látrány: Kolláti-legclő, fühálózás, 2001. X. 5., Podlussány A., Rozner I., Rozner Gy.; Látrány: Kolláti-legelő, fühálózás, 2000. VI. 4., Podlussány A., Rozner I., Rozner Gy.

Eutrichapion punctigerum (Paykull, 1792) Látrány: Kolláti-legelő, fühálózás, 2000. IV. 29., Rozner I; Látrány: Látrányi-legelö, 2001. IV. 12., Szalóki D., Rozner Gy.; Látrány: Kolláti-lcgelö, fühálózás, 2001. IV. 26., Podlussány A., Rozner 1., Rozner Gy.; Látrány: Birkás-legelö, fühálózás, 2001. IV. 26., Podlussány A., Rozner I., Rozner Gy.; Látrány: Kolláti-legelö, 2001. VI. 16., Rozner Gy.; Látrány: Birkás-legclő (4. számú terület), fühálózás, 2002. IV. 26., Podlussány A., Rozner I., Rozner Gy.; Látrány: Nyires-legelő, fühálózás, 2002. IV. 26., Podlussány A., Rozner 1., Rozner Gy.; Látrány: Kolláti-legelö (1. számú terület), fühálózás, 2002. IV. 26., Podlussány A., Rozner I., Rozner Gy.; Látrány: Birkás-legelő (5. számú tcrület), fühálózás, 2002. V. 4., Merkl O. Látrány, 1998. VI. 22., Rozner Gy.

Eutrichapion viciae (Paykull, 1800) - Látrány: Birkás-legelö, fühálózás, 2001. IV. 26., Podlussány A., Rozner I., Rozner Gy.

Holotrichapion aestimatum (Faust, 1891) Látrány: Kolláti-legelő, fühálózás, 2001. IV. 26., Podlussány A., Rozner I., Rozner Gy.

Holotrichapion pisi (Fabricius, 1801) - Látrány: Kolláti-legelő, fühálózás, 2001. IV. 26., Podlussány A., Rozner l., Rozner Gy.; Látrány: Birkás-legelö, fühálózás, 2001. X. 5., Podlussány A., Rozner I., Rozner Gy.; Látrány: Kolláti-legclö, fühálózás, 2001. X. 5., Podlussány A., Rozner l., Rozner Gy.; Látrány: Kolláti-legelő (1. számú terület), fühálózás, 2002. IV. 26., Podlussány A., Rozner I., Rozner Gy.; Látrány: Birkás-legelö (4. számú terület), fühálózás, 2002. IV. 26., Podlussány A., Rozner l., Rozner Gy.; Látrány: Nyíres-legclő, fühálózás, 2002. IV. 26., Podlussány A., Rozner I., Rozner Gy.

Ischnopterapion loti (Kirby, 1808) - Látrány: Kolláti-legelö, 2000. VI. 3., Rozner 1.; Látrány: Kolláti-legelő, 2001. IV. 25., Rozner Gy.; Látrány: Birkás-legelő, fühálózás, 2001. IV. 26., Podlussány A., Rozner I., Rozner Gy.; Látrány: Kolláti-legelö, fühálózás, 2000. Vl. 4., Podlussány A., Rozner I., Rozner Gy; Látrány: Kolláti-legelö, 1999. III. 5., Rozner Gy.

Ischnopterapion virens (Herbst, 1797) - Látrány: Kolláti-legelö, 2000. VI. 3., Rozner I.; Látrány: Birkás-legelö, fühálózás, 2000. VI. 4., Podlussány A., Rozner I., Rozner Gy.; Látrány: Birkás-legelő, fühálózás, 2001. X. 5., Podlussány A., Rozner I., Rozner Gy.; Látrány: Kolláti-legclő, fühálózás, 2001. X. 5., Podlussány A., Rozner I., Rozner Gy,; Látrány: Birkás-legclö (4. számú terület), fühálózás, 2002. IV. 26., Podlussány A., Rozner l., Rozner Gy.; Látrány: Kolláti-legelö, fühálózás, 2000. VI. 4., Podlussány A., Rozner I., Rozner Gy.
Melanapion minimum (Herbst, 1797) - Látrány: Birkás-legelö, 2000. IV. 20., Rozner Gy.; Látrány: talajcsapda, 1998. IV. 24.-V. 15., Rozner Gy.

Omphalapion hookerorum (Kirby, 1808) Látrány: Birkás-legelő, fühálózás, 2000. VI. 4., Podlussány A., Rozner I., Rozner Gy.; Látrány: Kolláti-legelö, fühálózás, 2001. IV. 26., Podlussány A., Rozner 1., Rozner Gy.

Oxystoma craccae (Linnć, 1767) - Látrány: Birkás-legelő, 2000. IV. 20., Rozner Gy.; Látrány: Birkás-legelö (4. számú terület), fühálózás, 2002. IV. 26., Podlussány A., Rozner I., Rozner Gy.

*Oxystoma subulatum (Kirby, 1808) - Látrány: Birkás-legelő (4. számú terület), fühálózás, 2002. IV. 26., Podlussány A., Rozner I., Rozner Gy.

Perapion affine (Kirby, 1808) - Látrány: Kollátilegelö, 2000. VI. 3., Rozner I.; Látrány: Birkás-legelő, fühálózás, 2001. IV. 26., Podlussány A., Rozner I., Rozner Gy.; Látrány: Birkás-legelö, fühálózás, 2001. VI. 26., Rozner I.; Látrány: Birkás-legelő (4. számú terület), fühálózás, 2002. IV. 26., Podlussány A., Rozner I., Rozner Gy.; Látrány, 1998. Vl. 22., Rozner Gy.; Látrány: Látránypuszta, 1999. VII. 25., Rozner I.; Látrány: Kolláti-lcgelő, fühálózás, 2000. VI. 4., Podlussány A., Rozner I., Rozner Gy.

Perapion curtirostre (Germar, 1817) - Látrány: Birkás-lcgelő, fühálózás, 2000. V1. 4., Podlussány A., Rozner I., Rozner Gy.; Látrány: Kolláti-legelö, fühálózás, 2001. IV. 26., Podlussány A., Rozner I., Rozner Gy.; Látrány: Kolláti-legelö, fühálózás, 2000. VI. 4., Podlussány A., Rozner I., Rozner Gy.

Perapion oblongum (Gyllenhal, 1839) - Látrány: Látrányi-legelö, 2001. IV. 12., Szalóki D., Rozner Gy.; Látrány: Birkás-legelö (4. számú terület), fühálózás, 2002. IV. 26., Podlussány A., Rozner I., Rozner Gy.; Látrány: Látránypuszta, fühálózás, 2002. VI. 30., Merkl O.

Perapion violaceum (Linné, 1808) - Látrány: Birkás-legelö, fühálózás, 2000. VI. 4., Podlussány A., Rozner I., Rozner Gy; Látrány: Látrányi-legelö, 2001. IV. 12., Szalóki D., Rozner Gy.; Látrány: Kolláti-legelő (1. számú terület), fühálózás, 2002. IV. 26., Podlussány A., Rozner I., Rozner Gy.; Látrány: Birkảs-legclő (4. számú terület), fühálózás, 2002. IV. 26., Podlussány A., Rozner 1., Rozner Gy.; Látrány: Birkás-lcgelő (5. számú tcrület), fühálózás, 2002. V. 4., Merkl O.; Látrány: talajcsapda, 1998. IV. 24.-V. 15., Rozner Gy.; Látrány, 2001. IV. 29., Szalóki D.; Látrány, 1999. IV. 14., Rozner Gy.

Protapion apricans (Herbst, 1797) - Látrány: Kolláti-legelö, 2000. VI. 3., Rozner I.; Látrány: Birkás-legclő, fühálózás, 2001. VI. 26., Rozner I.; Látrány: Kolláti-legelő, fühálózás, 2000. VI. 4., Podlussány A., Rozner I., Rozner Gy.

Protapion assimile (Kirby, 1808) - Látrány: Birkás-legclö (4. számú tcrület), fühálózás, 2002. IV. 26., Podlussány A., Rozner 1., Rozner Gy.; Látrány: 
Birkás-legelő (5. számú terület), fühálózás, 2002. V. 4., Merkl O.; Látrány, 1998. VI. 22., Rozner Gy.; Látrány: Látránypuszta, 1999. VII. 25., Rozner 1.

Protapion dissimile (Germar, 1817) - Látrány: Kolláti-legelő, 2001. VI. 16., Rozner Gy.; Látrány: Birkás-legelő, fühálózás, 2001. VI. 26., Rozner 1.

Protapion filirostre (Kirby, 1808) - Látrány, 2001. V. 18., Szalóki D.

Protapion fulvipes (Fourcroy, 1785) - Látrány: Kolláti-legelő, 2000. V. 13., Kondorosy E., Rozner Gy.; Látrány: Kolláti-legelö, 2000. VI. 3., Rozner I.; Látrány: Kolláti-lcgelő, 2001. IV. 25., Rozner Gy.; Látrány: Kolláti-legelö, fühálózás, 2001. IV. 26., Podlussány A., Rozner I., Rozner Gy.; Látrány: Birkás-legelö, fühálózás, 2001. IV. 26., Podlussány A., Rozner I., Rozner Gy.; Látrány: Kolláti-legelő, 2001. VI. 16., Rozncr Gy.; Látrány: Birkás-legelő, fühálózás, 2001. X. 5., Podlussány A., Rozner I., Rozner Gy.; Látrány: Birkás-lcgelö (4. számú terület), fühálózás, 2002. IV. 26., Podlussány A., Rozner I., Rozner Gy.; Látrány: talajcsapda, 1998. IV. 24.-V. 15., Rozncr Gy.; Látrány: Kolláti-legelő, fühálózás, 2000. VI. 4., Podlussány A., Rozner I., Rozner Gy.; Látrány: Látránypuszta, fühálózás, 1998. VI. 27-28., Rozner I.; Látrány: Birkás-legelő, 2000. IV. 29., Rozner Gy.

Protapion nigritarse (Kirby, 1808) - Látrány: Birkás-legelő, fühálózás, 2001. IV. 26., Podlussány A., Rozner I., Rozner Gy.; Látrány: Kolláti-legelő, 2001. Vl. 16., Rozner Gy.; Látrány: Kolláti-legelö, fühálózás, 2000. VI. 4., Podlussány A., Rozner I., Rozner Gy.

Protapion ononidis (Gyllenhal, 1827) - Látrány: Kolláti-legelö, 2000. IV. 11., Rozner Gy.; Látrány: Kolláti-legelö, 2000. VI. 3., Rozner I; Látrány: Birkás-lcgelő, fühálózás, 2000. VI. 4., Podlussány A., Rozner I., Rozner Gy.; Látrány: Kolláti-legelő, fühálózás, 2001. IV. 26., Podlussány A., Rozner I., Rozner Gy.; Látrány: Birkás-legelő, fühálózás, 2001. IV. 26., Podlussány A., Rozner I., Rozner Gy.; Látrány, 2001. V. 18., Szalóki D.; Látrány: Kollátilegelö, 2001. VI. 16., Rozner Gy.; Látrány (4. számú terület), 2001. VII. 3., Kondorosy E.; Látrány: Kolláti-legelö (1. számú terület), fühálózás, 2001. VII. 5., Merkl O.; Látrány: Birkás-legclő (5. számú terület), fühálózás, 2002. V. 4., Merkl O.; Látrány, 1998. VI. 22., Rozner Gy.; Látrány: Kolláti-legelö, fühálózás, 2000. VI. 4., Podlussány A., Rozner I., Rozner Gy.; Látrány (1. számú terület), 2001. VII. 10., Kondorosy E.; Látrány (3. számú terület), 2001. VII. 10., Kondorosy E.; Látrány: Látránypuszta, fühálózás, 1998. VI. 27-28., Rozner I.; Látrány: Birkáslegelö, 1999. IV. 1-14., talajcsapda, Rozner Gy.; Látrány (4. számú terület), 2001. VII. 8., Rozner Gy.

Protapion ruficrus (Germar, 1817) - Látrány: Kolláti-legelö, fühálózás, 2000. VI. 4., Podlussány A., Rozner 1., Rozner Gy.; Látrány, 2001. IV. 29., Szalóki D.
Protapion schoenherri (Boheman, 1839) Látrány: Kolláti-legelö, fühálózás, 2000. IV. 29., Rozner I.; Látrány: Kolláti-legelő, fühálózás, 2001. IV. 26., Podlussány A., Rozner I., Rozner Gy.; Látrány: Birkás-legelő, fühálózás, 2001. IV. 26., Podlussány A., Rozncr I., Rozner Gy.; Látrány: Kolláti-legelö (1. számú terület), fühálózás, 2002. IV. 26., Podlussány A., Rozncr I., Rozner Gy.; Látrány: Birkás-legelő (5. számú tcrület), fühálózás, 2002. V. 4., Merkl O.; Látrány, 2001. IV. 29., Szalóki D.; Látrány: Látránypuszta, fühálózás, 2002. VI. 30, Merkl O.

Protapion trifolii (Linné, 1768) - Látrány: Birkás-legelö, fühálózás, 2001. IV. 26., Podlussány A., Rozner I., Rozner Gy.; Látrány: "dél", 2001. VIlI. 24., Kondorosy E.; Látrány: Birkás-legelő (4. számú tcrület), fühálózás, 2002. IV. 26., Podlussány A., Rozner I., Rozner Gy; Látrány: Kolláti-legelö, fühálózás, 2000. VI. 4., Podlussány A., Rozner I., Rozner Gy.

Protapion varipes (Germar, 1817) - Látrány: Látrányi-legclö, 2001. IV. 12., Szalóki D., Rozner Gy.; Látrány: Birkás-legelő, fühálózás, 2001. X. 5., Podlussány A., Rozner I, Rozner Gy.

Pseudapion fulvirostre (Gyllenhal, 1833) Látrány: Birkás-legelő, fühálózás, 2001. X. 5., Podlussány A., Rozner I., Rozner Gy.

Squamapion elongatum (Germar, 1817) Látrảny: Birkás-legelö, fühálózás, 2001. IV. 26., Podlussány A., Rozner I., Rozner Gy,; Látrány: Birkás-legelö, fühálózás, 2001. X. 5., Podlussány A., Rozner I., Rozner Gy.; Látrány: Kolláti-legelő, fühálózás, 2001. X. 5., Podlussány A., Rozner I., Rozner Gy.; Látrány: Látránypuszta, 1999. VII. 25., Rozner I.; Látrány: Kolláti-legelö, fühálózás, 2000. VI. 4., Podlussány A., Rozner I., Rozner Gy.; Látrány: Látránypuszta, fühálózás, 2002. VI. 30., Merkl O.

Squamapion oblivium (Schilsky, 1902) Látrány: Látrányi-legelő, 2001. IV. 12., Szalóki D., Rozner Gy.

Squamapion vicinum (Kirby, 1808) - Látrány: Birkás-legelő, fühálózás, 2001. IV. 26., Podlussány A., Rozner I., Rozner Gy.; Látrány: Birkás-legelő, fühálózás, 2001. X. 5., Pơdlussány A., Rozner I., Rozner Gy.; Látrány: Kolláti-legelő, fühálózás, 2001. X. 5., Podlussány A., Rozner I., Rozner Gy.; Látrány: Birkás-legelő (4. számú terület), fühálózás, 2002. IV. 26., Podlussány A., Rozner I., Rozner Gy.; Látrány: Nyírcs-legelő, fühálózás, 2002. IV. 26., Podlussány A., Rozner I., Rozner Gy.

Stenopterapion meliloti (Kirby, 1808) - Látrány: Kolláti-legelő, 2000. VI. 3., Rozner I.; Látrány: Birkás-legelö, fühálózás, 2001. X. 5., Podlussány A., Rozner I., Rozner Gy.; Látrány: Kolláti-legelő, fühálózás, 2001. X. 5., Podlussány A., Rozner 1., Rozner Gy.; Látrány: Kolláti-legelő (1. számú terület), fühálózás, 2002. IV. 26., Podlussány A., Rozner I., Rozner Gy.; Látrány: Látránypuszta, 1999. VII. 25., Rozner I.; Látrány: Kolláti-legelö, fühálózás, 2000. VI. 4., Podlussány A., Rozner l., Rozner Gy. 
Stenopterapion tenue (Kirby, 1808) - Látrány: Birkás-legelö, fühálózás, 2001. X. 5., Podlussány A., Rozner I., Rozner Gy.; Látrány: Kolláti-legelö, fühálózás, 2001. X. 5., Podlussány A., Rozner I., Rozner Gy.

Taeniapion urticarium (Herbst, 1784) - Látrány: Kolláti-legelő, fühálózás, 2001. IV. 26., Podlussány A., Rozner l., Rozner Gy.; Látrány: Birkás-legelö, fühálózás, 2001. IV. 26., Podlussány A., Rozner I., Rozner Gy.; Látrány: Birkás-legelö, fühálózás, 2001. X. 5., Podlussány A., Rozner l., Rozner Gy.; Látrány: Kolláti-legelő, fühálózás, 2001. X. 5., Podlussány A., Rozner 1., Rozner Gy.; Látrány: Kolláti-legelö (1. számú terület), fühálózás, 2002. IV. 26., Podlussány A., Rozner I., Rozner Gy.; Látrány: Birkás-legelö (4. számú terület), fühálózás, 2002. IV. 26., Podlussány A., Rozner I., Rozner Gy.; Látrány: Nyíres-legelö, fühálózás, 2002. IV. 26., Podlussány A., Rozner I., Rozner Gy.

\section{Nanophyidae}

(meghatározta: Podlussány Attila)

Dieckmanniellus helveticus (Tournier, 1867) Látrány: Birkás-legelö, fühálózás, 2001. IV. 26., Podlussány A., Rozner I., Rozner Gy.; Látrány: Kolláti-legelö, fühálózás, 2000. VI. 4., Podlussány A., Rozner I., Rozner Gy.

Dieckmanniellus nitidulus (Gyllenhal, 1838) Látrány: Birkás-legelö, fühálózás, 2000. VI. 4., Podlussány A., Rozner I., Rozner Gy.; Látrány: Birkás-legelö, fühálózás, 2001. IV. 26., Podlussány A., Rozner I., Rozner Gy.; Látrány: Kolláti-legelö, rostálás, 2001. X. 5., Podlussány A., Rozner 1., Rozner Gy.; Látrány: Kolláti-legelö, fühálózás, 2000. VI. 4., Podlussány A., Rozner I., Rozner Gy.

Nanophyes marmoratus (Goeze, 1777) Látrảny: Birkás-legelö, fühálózás, 2000. VI. 4., Podlussány A., Rozner I., Rozner Gy.; Látrány: Birkás-legelő, fühálózás, 2001. IV. 26., Podlussány A., Rozner 1., Rozner Gy.; Látrány: Kolláti-legelö (1. számú terület), fühálózás, 2001. VII. 5., Merkl O.; Látrány: Birkás-legelö, fühálózás, 2001. X. 5., Podlussány A., Rozner l., Rozner Gy.; Látrány: Birkás-legelö (4. számú tcrület), fühálózás, 2002. IV. 26., Podlussány A., Rozner I., Rozner Gy.; Látrány: Birkás-legelö (5. számú terület), fühálózás, 2002. V. 4., Merkl O.; Látrány, 1998. VI. 22., Rozner Gy.; Látrány (3. számú terület), 2001. VII. 10., Kondorosy E.; Látrány: Látránypuszta, fühálózás, 1998. V1. 2728., Rozner 1.; Látrány: Kolláti-legelô, 1999. VII. 12., Rozner Gy; Látrány: Látránypuszta, fühálózás, 2002. VI. 30., Mcrkl O.

Nanophyes brevis Boheman, 1845 - Látrány: Birkás-legelö, fúhálózás, 2000. VI. 4., Podlussány A., Rozner l., Rozner Gy.; Látrány: Birkás-legclö, fühálózás, 2001. IV. 26., Podlussány A., Rozner 1., Rozner Gy.; Látrány: Kolláti-legelő (1. számú terület), fühálózás, 2001. VII. 5., Merkl O.; Látrány: Birkás-legclö, fühálózás, 2001. X. 5., Podlussány A.,
Rozner I., Rozner Gy.; Látrány: Birkás-legelö (4. számú terület), fühálózás, 2002. IV. 26., Podlussány A., Rozner I., Rozner Gy.; Látrány, 1998. VI. 22., Rozner Gy.; Látrány: Látránypuszta, fühálózás, 2002. VI. 30., Merkl O.

\section{Brachyceridae \\ (meghatározta: Podlussány Attila)}

Brachycerus foveicollis Gyllenhal, 1833 (3. ábra) - Látrány: Kolláti-legclö, 2000. IV. 11., Rozner Gy.; Látrány: talajcsapda, 1998. IV. 24.-V. 15., Rozner Gy.; Látrány, 2001. IV. 12., Szalóki D. - A föleg Afrikában, illetve a Mediterráncumban elterjedt Brachycerus genusznak ez a legészakibb elöfordulású faja. Száraz gyeptársulások (homok- és löszpuszták, szikesek, sztyeplejtők) jellegzetes, ritka bogara. Lelöhelyadatainak (4. ábra) többségéről csak több évtizeddel ezelött került elö; csupán Csévharasztról és Látrányból ismerjük újabb előfordulását. Előfordulási adatai: Akasztó (CS 67), Aszófö (YN 10), Békéscsaba (ES 06), Csévharaszt (CT 83), Dörgicse (YM 09), Fenyöfö (YN 04), Göd (CT 68), Látrány (YM 08), Nagyvázsony (YN 00), Pápa (XN 84), Szabadszállás (CS 69), Szilvásvárad (DU 52), Tard (DU 60), Veszprém (YN 22).

\section{Curculionidae}

(meghatározta: Podlussány Attila)

Acalyptus sericeus Gyllenhal, 1836 - Látrány: Birkás-legelö, 2000. IV. 20., Rozner Gy. Alophus kaufmanni Stierlin, 1884 - Látrány: Kolláti-legelö, 2000. IV. 11., Rozner Gy.; Látrány: Birkás-legclö, 2001. IV. 25., Rozner Gy.; Látrány: Kolláti-legelö, 2001. Ill. 10., Rozner Gy. Alophus triguttatus (Fabricius, 1775) - Látrány: Kolláti-legelö, fühálózás, 2001. IV. 26., Podlussány A., Rozner I., Rozner Gy.; Látrány: Birkás-legelö, fühálózás, 2001. IV. 26., Podlussány A., Rozner I., Rozner Gy.; Látrány: talajcsapda, 1998. IV. 24.-V. 15., Rozner Gy.; Látrány: Kolláti-legelö, 2001. III. 10., Rozner Gy.; Látrány: Kolláti-legelö, talajcsapda, 1999. IV. 15-V. 22., Rozner Gy. Amalus scortillum (Herbst, 1795) - Látrảny: Kolláti-legelő, fühálózás, 2000. VI. 4., Podlussány A., Rozner I., Rozner Gy. Anthonomus bituberculatus Thomson, 1868 Látrány: Birkảs-legelö, kopogtatás, 2001. IV. 26., Podlussány A., Rozner I., Rozner Gy. Anthonomus pedicularius (Linné, 1758) Látrány: Kolláti-legclö, 2000. IV. 29., kopogtatás, Rozner I.; Látrány: Kolláti-legelö, 2001. IV. 25., Rozner Gy.; Látrány: Kolláti-legelö, fühálózás, 2001. IV. 26., Podlussány A., Rozner I., Rozner Gy.; Látrány: Birkás-legelö, kopogtatás, 2001. IV. 26., Podlussány A., Rozner I., Rozner Gy.; Látrány: Birkás-legclö (4. számú terület), kopogtatás, 2002. IV. 26., Podlussány A., Rozner I., Rozner Gy. 
Anthonomus phyllocola (Herbst, 1795) Látrány: Birkás-legclő, kopogtatás, 2001. IV. 26., Podlussány A., Rozner I., Rozner Gy.

Anthonomus rubi (Herbst, 1795) - Látrány: Birkás-legelö, 2000. IV. 20., Rozner Gy.; Látrány: Kolláti-legelö, 2000. V. 13., Kondorosy E., Rozner Gy.; Látrány: Kolláti-legelö, 2001. IV. 25., Rozner Gy.; Látrány: Kolláti-legclö, fühálózás, 2001. X. 5., Podlussány A., Rozner I., Rozner Gy.; Látrány: Kolláti-legelố (1. számú terület), fühálózás, 2002. IV. 26., Podlussány A., Rozner I., Rozner Gy.; Látrány: Birkás-legelö (4. számú terület), kopogtatás, 2002. IV. 26., Podlussány A., Rozner I., Rozner Gy.; Látrány: Nyíres-legelö, fühálózás, 2002. IV. 26., Podlussány A., Rozner I., Rozner Gy.; Látrány, 1999. IV. 14., Rozner Gy.; Látrány: Birkás-legelö, 2001. Vl. 14., Rozner Gy. Anthonomus ulmi (De Geer, 1775) - Látrány: Birkás-legelö, kopogtatás, 2001. X. 5., Podlussány A., Rozner I., Rozner Gy.

Bagous lutulentus (Gyllenhal, 1813) - Látrány: Birkás-legelö, autós hálózás, késő délután, 2002. V. 4., Merkl O.

Barypeithes chevrolati (Boheman, 1843) Látrány: Birkás-legclő (4. számú terület), rostálás, 2002. IV. 26., Podlussány A., Rozner I., Rozner Gy.

Baris artemisiae (Herbst, 1795) - Látrány: Kolláti-legelö, 2000. IV. 11., Rozner Gy.; Látrány: Látrányi-legelö, 2001. IV. 12., Szalóki D., Rozner Gy.; Látrány: Birkás-legclő (4. számú terület), fühálózás, 2002. IV. 26., Podlussány A., Rozner l., Rozner Gy.

Baris atramentaria (Boheman, 1836) - Látrány: Kolláti-legelő, 2000. IV. 11., Rozner Gy.; Látrány: Látrányi-legelö, 2001. IV. 12., Szalóki D., Rozner Gy. Baris coerulescens (Scopoli, 1763) - Látrány: Kolláti-legelő, 2000. IV. 11., Rozner Gy.; Látrány: Birkás-legelő, fühálózás, 2001. IV. 26., Podlussány A., Rozner I., Rozner Gy.; Látrány: Kolláti-legelö, fühálózás, 2001. X. 5., Podlussány A., Rozner 1., Rozner Gy.; Látrány: Kolláti-legelő (1. számú terület), fühálózás, 2002. IV. 26., Podlussány A., Rozner I., Rozner Gy.; Látrány: Birkás-legelö (4, számú terület), fühálózás, 2002. IV. 26., Podlussány A., Rozner I., Rozner Gy.; Látrány: Birkás-legelö, 1999. IIl. 5 31., talajcsapda, Rozner Gy.

Baris gudenusi Schultze, 1901 - Látrány: Birkáslegelő, fühálózás, 2000. VI. 4., Podlussány A., Rozner I., Rozner Gy.

Brachonxyx pineti (Paykull, 1792) - Látrány: Birkás-legelö, 2000. IV. 20., Rozner Gy.; Látrány: Kolláti-legelö, kopogtatás, 2001. IV. 26., Podlussány A., Rozner I., Rozncr Gy.; Látrány: Birkás-lcgelö, kopogtatás, 2001. IV. 26., Podlussány A., Rozner I., Rozncr Gy.; Látrány: Birkás-legelő, kopogtatás, 2001. X. 5., Podlussány A., Rozner I., Rozner Gy.; Látrány: Kolláti-legelö (1. számú terület), fühálózás, 2002. IV. 26., Podlussány A., Rozner I., Rozner Gy.; Látrány (2. számú terület), 2001. VII. 10., Kondorosy E.; Látrány: Látránypuszta, fühálózás,
2002. VI. 30, Merkl O.

Brachysomus setiger (Gyllenhal, 1840) Látrány: Kolláti-legelő (1. számú terület), rostálás, 2002. IV. 26., Podlussány A., Rozner I., Rozner Gy.; Látrány: Birkás-legelö (4. számú terület), rostálás, 2002. IV. 26., Podlussány A., Rozner I., Rozner Gy.; Látrány: talajcsapda, 1998. IV. 24.-V. 15., Rozner Gy.

Ceutorhynchus alliariae $(\mathrm{H}$. Brisout de Barneville, 1860) - Látrány: talajcsapda, 1998. IV. 24.-V. 15., Rozner Gy.

Ceutorhynchus atomus Boheman, 1845 Látrány: Kolláti-legelö (1. számú terület), fühálózás, 2002. IV. 26., Podlussány A., Rozner I., Rozner Gy.; Látrány: Birkás-legelő (4. számú terület), fühálózás, 2002. IV. 26., Podlussány A., Rozner I., Rozner Gy.

*Ceutorhynchus chlorophanus Rouget, 1857 Látrány: Kolláti-legelő (1. számú terület), fühálózás, 2002. IV. 26., Podlussány A., Rozner I., Rozner Gy.

Ceutorhynchus constrictus (Marsham, 1802) Látrány: Birkás-legelő, fühálózás, 2001. IV. 26., Podlussány A., Rozner I., Rozner Gy.

Ceutorhynchus contractus (Marsham, 1802) Látrány: Kolláti-legelö, fühálózás, 2001. IV. 26., Podlussány A., Rozner I., Rozner Gy.; Látrány: Birkás-legelö, fühálózás, 2001. IV. 26., Podlussány A., Rozncr I., Rozner Gy.; Látrány: Birkás-legelö, fühálózás, 2001. X. 5., Podlussány A., Rozner I., Rozner Gy.; Látrány: Kolláti-legelö, fühálózás, 2001. X. 5., Podlussány A., Rozner I., Rozner Gy.; Látrány: Kolláti-lcgelö (1. számú terület), fühálózás, 2002. IV. 26., Podlussány A., Rozner I., Rozner Gy.; Látrány: Birkás-legelő (4. számú terület), fühálózás, 2002. IV. 26., Podlussány A., Rozner I., Rozner Gy.

Ceutorhynchus erysimi (Fabricius, 1787) Látrány: Kolláti-legelö, 2000. VI. 3., Rozner I.; Látrány: Kolláti-legelö, fühálózás, 2001. IV. 26., Podlussány A., Rozner I., Rozner Gy.; Látrány: Birkás-legelô, fühálózás, 2001. IV. 26., Podlussány A., Rozner I., Rozner Gy.; Látrány: Birkás-legelő, fühálózás, 2001. X. 5., Podlussány A., Rozner I., Rozner Gy.; Látrány: Kolláti-legelő, fühálózás, 2001. X. 5., Podlussány A., Rozner I., Rozner Gy.; Látrány: Kolláti-legelö, fühálózás, 2000. VI. 4., Podlussány A., Rozner I., Rozner Gy.

Ceutorhynchus floralis (Paykull, 1792) Látrány: Kolláti-legelő, fühálózás, 2000. IV. 29., Rozner I.; Látrány: Kolláti-legelő, 2000. VI. 3., Rozner 1.; Látrány: Birkás-legelö, fühálózás, 2000. VI. 4., Podlussány A., Rozner 1., Rozner Gy.; Látrány: Kolláti-legclő, 2001. IV. 25., Rozner Gy.; Látrány: Kolláti-legelö, fühálózás, 2001. IV. 26., Podlussány A., Rozner I., Rozner Gy.; Látrány: Birkás-legelő, fühálózás, 2001. IV. 26., Podlussány A., Rozner I., Rozner Gy.; Látrány: Birkás-legelö, fühálózás, 2001. VI. 26., Rozner I.; Látrány: Kolláti-legelő (1. számú terület), fühálózás, 2002. IV. 26., Podlussány A., Rozner I., Rozner Gy.; Látrány: Birkás-legelő (4. számú terület), fühálózás, 2002. IV. 26., Podlussány A., Rozner l., Rozner Gy.; Látrány: 
Birkás-legelö, 1999. III. 5-31., talajcsapda, Rozner Gy.; Látrány: Kolláti-lcgelő, fühálózás, 2000. VI. 4., Podlussány A., Rozner I., Rozner Gy.

Ceutorhynchus hampei (Ch. Brisout de Barneville, 1869) - Látrány, 2001. VII. 10., Kondorosy E.; Látrány: Kolláti-legelő, fühálózás, 2001. X. 5., Podlussány A., Rozner I., Rozner Gy.

Ceutorhynchus interjectus Schultzc, 1903 Látrány: Birkás-lcgelő, fühálózás, 2000. VI. 4., Podlussány A., Rozner 1., Rozner Gy.; Látrány: Kolláti-legclö, fühálózás, 2000. VI. 4., Podlussány A., Rozner I., Rozner Gy.

Ceutorhynchus napi Gyllenhal, 1837 - Látrány: Birkás-lcgelö, fühálózás, 2001. VI. 26., Rozner I.; Látrány: Kolláti-legelő (1. számú tcrület), fühálózás, 2002. IV. 26., Podlussány A., Rozner I., Rozner Gy.; Látrány, 1998. III. 30-31., Rozner Gy.

Ceutorhynchus obstrictus (Marsham, 1802) . Látrảny: Birkás-legelő, 2000. IV. 20., Rozner Gy.; Látrány: Kolláti-legelö, 2000. VI. 3., Rozner I.; Látrány: Birkás-lcgelö, fühálózás, 2000. VI. 4., Podlussány A., Rozner I., Rozner Gy.; Látrány: Kolláti-legclö, 2001. IV. 25., Rozner Gy.; Látrány: Kolláti-legelö, fühálózás, 2001. IV. 26., Podlussány A., Rozner I., Rozner Gy.; Látrány: Birkás-legelö, fühálózás, 2001. IV. 26., Podlussány A., Rozner I., Rozner Gy.; Látrány: Birkás-legelő, fühálózás, 2001. VI. 26., Rozner I.; Látrány: Kolláti-legelö (1. számú terület), fühálózás, 2002. IV. 26., Podlussány A., Rozner I., Rozner Gy.; Látrány: Birkás-legelő (4. számú terület), fühálózás, 2002. IV. 26., Podlussány A., Rozner I., Rozner Gy; Látrány: Nyíres-legelö, fühálózás, 2002. IV. 26., Podlussány A., Rozner I., Rozner Gy.; Látrány: Birkás-legelö (5. számú terület), fühálózás, 2002. V. 4., Mcrkl O.; Látrány: Birkás-legelö, Tetves-patak, 2001. IV. 25., Rozner Gy.; Látrány: talajcsapda, 1998. IV. 24.-V. 15., Rozner Gy.; Látrány: Kolláti-legclő, fühálózás, 2000. VI. 4., Podlussány A., Rozner I., Rozner Gy.; Látrány (1. számú terület), 2001. VII. 10., Kondorosy E.; Látrány (2. számú terület), 2001. VII. 10., Kondorosy E.; Látrány, 2001. IV. 29., Szalóki D.; Látrány: Birkáslegelő, 2001. IV. 25., Rozner Gy.

Ceutorhynchus pallidactylus (Marsham, 1802) Látrány: Kolláti-legelö, 2000. VI. 3., Rozner 1.; Látrány: Birkás-legelő, fühálózás, 2000. VI. 4., Podlussány A., Rozner I., Rozner Gy.; Látrány: Kolláti-legclö, 200I. IV. 25., Rozner Gy.; Látrány: Birkás-legelö, fühálózás, 2001. IV. 26., Podlussány A., Rozner l., Rozner Gy.; Látrány: Kolláti-legelö (1. számú terület), fühálózás, 2002. IV. 26., Podlussány A., Rozner 1., Rozner Gy.; Látrány: Birkás-legelö (4. számú terület), fühálózás, 2002. IV. 26., Podlussány A., Rozner I., Rozner Gy.; Látrány: Nyires-legelö, fühálózás, 2002. IV. 26., Podlussány A., Rozner I., Rozner Gy.; Látrány: talajcsapda, 1998. IV. 24.-V. 15., Rozner Gy.; Látrány: Kolláti-legelö, fühálózás, 2000. VI. 4., Podlussány A., Rozner 1., Rozner Gy.; Látrány, 1998. IIl. 30-31., Rozner Gy.
Ceutorhynchus picitarsis Gyllenhal, 1837 Látrány: Kolláti-legelö, fühálózás, 2001. X. 5., Podlussány A., Rozner I., Rozner Gy.

Ceutorhynchus pulvinatus (Gyllenhal, 1837) Látrány: Kolláti-legclő, fühálózás, 2001. IV. 26., Podlussány A., Rozner I., Rozner Gy.; Látrány: Birkás-legelö, fühálózás, 2001. IV. 26., Podlussány A., Rozner 1., Rozner Gy.; Látrány: Birkás-legclő (4. számú terület), fühálózás, 2002. IV. 26., Podlussány A., Rozner I., Rozner Gy.

Ceutorhynchus puncticollis Boheman, 1845 Látrány: Birkás-legelő (5. számú tcrület), fühálózás, 2002. V. 4., Merkl O.

Ceutorhynchus roberti Gyllenhal, 1837 . Látrány: Birkás-legelő (4. számú terület), fühálózás, 2002. IV. 26., Podlussány A., Rozner l., Rozner Gy.

*Ceutorhynchus scrobicollis Neresheimer et Wagner, 1924 - Látrány: Birkás-legelő, fühálózás, 2001. VI. 26., Rozner I.

Ceutorhynchus sisymbrii Dicckmann, 1966 Látrány: Birkás-legelő, fühálózás, 2000. VI. 4., Podlussány A., Rozner I., Rozner Gy.

Chromoderus affinis (Schrank, 1781) - Látrány: Kolláti-legelő, 2000. IV. 11., Rozner Gy.; Látrány: Kolláti-legelö (1. számú terület), fühálózás, 2001. VII. 5., Merkl O.; Látrány, 2001. VII. 4., Rozner Gy.

Cionus clairvillei Boheman, 1838 - Látrány: Birkás-legclö, 2000. IV. 29., Rozner Gy.

Cionus leonhardi Wingelmüller, 1914 - Látrány: Birkás-legelö, fühálózás, 2001. IV. 26., Podlussány A., Rozner I., Rozner Gy.; Látrány: Birkás-legelö, fühálózás, 2001. VI. 26., Rozner I.; Látrány: Birkás-legelö (4. számú terület), fühálózás, 2002. IV. 26. Podlussány A., Rozner l., Rozner Gy.; Látrány, 1998. VI. 22., Rozner Gy.

Cionus nigritarsis Reitter, 1904 - Látrány: Birkás-legclő, fühálózás, 2000. VI. 4., Podlussány A., Rozner I., Rozner Gy.; Látrány: Birkás-legelő, fühálózás, 2001. IV. 26., Podlussány A., Rozner I., Rozner Gy.; Látrány (1. számú terület), 2001. VII. 10., Kondorosy $\mathrm{E}$.

Cionus olivieri Rosenschöld, 1838 - Látrány: Birkás-legelő, fühálózás, 2001. VI. 26., Rozner I.; Látrány: "dél", 2001. VIIl. 24., Kondorosy E.

Cionus scophulariae (Linné, 1758) - Látrány: Birkás-legelő, fühálózás, 2000. VI. 4., Podlussány A., Rozner I., Rozner Gy.

Cionus thapsus (Fabricius, 1792) - Látrány: Birkás-legelö, fühálózás, 2000. VI. 4., Podlussány A., Rozner I., Rozner Gy.; Látrány: Birkás-legclö, fühálózás, 2001. IV. 26., Podlussány A., Rozner I., Rozner Gy.; Látrány: "dél", 2001. VIII. 24., Kondorosy E.; Látrány, 1998. VI. 22,, Rozner Gy.; Látrány: Látránypuszta, fühálózás, 1998. VI. 27-28., Rozncr I.

Cionus tuberculosus (Scopoli, 1763) - Látrány: Birkás-legelő (4. számú terület), fühálózás, 2002. IV. 26., Podlussány A., Rozner I., Rozner Gy.

Cleonis pigra (Scopoli, 1763) - Látrány: Kollátilcgelő (1. számú terület), fühálózás, 2002. IV. 26., 
Podlussány A., Rozner I., Rozner Gy.; Látrány: Birkás-legelő (4. számú terület), fühálózás, 2002. IV. 26., Podlussány A., Rozner I., Rozner Gy. Cleopus solani (Fabricius, 1792) - Látrány: Kolláti-legelő, 2000. VI. 3., Rozner I. Coeliastes lamii (Fabricius, 1792) - Látrány: Látrányi-legelő, 2001. IV. 12., Szalóki D., Rozner Gy.; Látrány: Kolláti-legelő, fühálózás, 2001. IV. 26., Podlussány A., Rozner I., Rozner Gy.; Látrány: Birkás-legelö, fühálózás, 2001. IV. 26., Podlussány A., Rozner I., Rozner Gy.; Látrány: Kolláti-legelő (1. számú terület), fühálózás, 2002. IV. 26., Podlussány A., Rozner I., Rozner Gy.; Látrány: Birkás-legelő (4. számú terület), fühálózás, 2002. IV. 26., Podlussány A., Rozner I., Rozner Gy.; Látrány: Nyíres-legelö, fühálózás, 2002. IV. 26., Podlussány A., Rozner I., Rozner Gy.

Coeliodes dryados (Gmelin, 1790) - Látrány: Birkás-legelő (4. számú terület), fühálózás, 2002. IV. 26., Podlussány A., Rozner I., Rozner Gy.

Coeliodes erythroleucos (Gmclin, 1790) -

Látrány: Birkás-legelő, fühálózás, 2001. VI. 26.

Rozner I.; Látrány: Birkás-legelő (4. számú terület), fühálózás, 2002. IV. 26., Podlussány A., Rozner I., Rozner Gy.

Coryssomerus capucinus (Beck, 1817) -

Látrány: Kolláti-legelő (1. számú terület), fühálózás, 2002. IV. 26., Podlussány A., Rozner I., Rozner Gy.; Látrány: Birkás-legclő (4. számú terület), fühálózás, 2002. IV. 26., Podlussány A., Rozner I., Rozner Gy.

Curculio crux Fabricius, 1776 - Látrány: Kollátilegelő (1. számú terület), fühálózás, 2002. IV. 26., Podlussány A., Rozner I., Rozner Gy.

Curculio elephas (Gyllenhal, 1836) - Látrány,

2001. VIII. 16., fénycsapda, Ábrahám L.

Curculio glandium Marsham, 1802 - Látrány:

Kolláti-legelö (1. számú terület), fühálózás, 2002. IV.

26., Podlussány A., Rozner I., Rozner Gy.; Látrány:

Birkás-legelő (4. számú terület), fühálózás, 2002. IV.

26., Podlussány A., Rozner I., Rozner Gy.; Látrány:

Birkás-legelö, 2001. VI. 14., Rozner Gy.

Curculio nucum Linnć, 1758 - Látrány, fénycsapda, 2001. VII. 11., Ábrahám L.

Curculio pyrrhoceras (Marsham, 1802) -

Látrány: Kolláti-legelő, 2001. IV. 25., Rozner Gy.; Látrány: Birkás-legelő, kopogtatás, 2001. IV. 26. Podlussány A., Rozner I., Rozner Gy.; Látrány: Birkás-legelö (4. számú terület), kopogtatás, 2002. IV. 26., Podlussány A., Rozner I., Rozner Gy.

Curculio villosus Fabricius, 1781 - Látrány: Kolláti-legelő, 2001. IV. 25., Rozner Gy.; Látrány: Birkás-legelö, kopogtatás, 2001. IV. 26., Podlussány A., Rozner l., Rozner Gy.; Látrány: Birkás-legelö (4. számú terület), kopogtatás, 2002. IV. 26., Podlussány A., Rozner I., Rozner Gy.

Cycloderes pilosulus (Herbst, 1795) - Látrány: Kolláti-legelő, 2001. VI. 16., Rozner Gy.; Látrány: "dél", 2001. VIII. 24., Kondorosy E.; Látrány: Kolláti-lcgclő, fühálózás, 2001. X. 5., Podlussány A.,
Rozner I., Rozner Gy.; Látrány, 2001. IV. 29., Szalóki D.; Látrány: Birkás-legelő, 1999. V. 22-VI،24., talajcsapda, Rozner Gy.

Cyphocleonus dealbatus (Gmelin, 1790) Látrány: Birkás-legelő, 2001. X. 5. fưhálózás, Rozner Gy. Datonychus melanostictus (Marsham, 1802) Látrány: Birkás-legelő, fühálózás, 2001. IV. 26., Podlussány A., Rozner I., Rozner Gy.

Datonychus paszlavszkyi (Kuthy, 1890) Látrány: Kolláti-legelő, fühálózás, 2000. VI. 4., Podlussány A., Rozner I., Rozner Gy.

Donus maculatus (W. Redtenbacher, 1842) Látrány: Birkás-legelő, fühálózás, 2001. IV. 26., Podlussány A., Rozner I., Rozner Gy.; Látrány: Kolláti-legelő, fühálózás, 2000. VI. 4., Podlussány A., Rozner I., Rozner Gy.

Dorytomus filirostris (Gyllenhal, 1836) -

Látrány: Birkás-legelö, kopogtatás, 2000. VI. 4., Podlussány A., Rozner I., Rozner Gy.; Látrány: Kolláti-legelő, rostálás, 2001. X. 5., Podlussány A., Rozner I., Rozner Gy.

Dorytomus longimanus (Forster, 1771) -

Látrány: Kolláti-legelö, 2000. V. 13., Kondorosy E., Rozner Gy.

*Dorytomus puberulus (Boheman, 1843) -

Látrány: Kolláti-legelő, 2001. IV. 25., Rozner Gy.

Dorytomus rufatus (Bedel, 1888) - Látrány: Bir-

kás-legelö, fühálózás, 2001. IV. 26., Podlussány A., Rozner I., Rozner Gy.; Látrány: Birkás-legelö, kopogtatás, 2001. X. 5., Podlussány A., Rozner I., Rozner Gy.

Dorytomus taeniatus (Fabricius, 1781) -

Látrány: Kolláti-legelö, 2000. V. 13., Kondorosy E., Rozner Gy.

Dorytomus tremulae (Fabricius, 1787) - Látrány: Birkás-legelő, rostálás, 2001. X. 5., Podlussány A., Rozner I., Rozner Gy.; Látrány: talajcsapda, 1998. IV. 24.-V. 15., Rozner Gy.

Eucoeliodes mirabilis (A. Villa \& G. B. Villa, 1835) - Látrány: Birkás-legclö, kopogtatás, 2000. VI. 4., Podlussány A., Rozner I., Rozner Gy.; Látrány: Kolláti-legelö, 2001. IV. 25., Rozner Gy.; Látrány: Birkás-legelö, 2001. VI. 26., kopogtatás, Rozner I.; Látrány: Birkás-legelő (4. számú terület), kopogtatás, 2002. IV. 26., Podlussány A., Rozner I., Rozner Gy.; Látrány: Birkás-legelő, Tetves-patak, 2001. IV. 25., Rozner Gy.

Eusomus ovulum Germar, 1824 - Látrány: Birkás-legelő, fühálózás, 2001. IV. 26., Podlussány A., Rozner I., Rozner Gy.; Látrány: Birkás-legelő, fühálózás, 2001. VI. 26., Rozner I.; Látrány: Kolláti-legelő (1. számú terület), fühálózás, 2002. IV. 26., Podlussány A., Rozner I., Rozner Gy.

Glocianus distinctus (Ch. Brisout de Barneville, 1870) - Látrány: Birkás-legelö, fühálózás, 2001. VI. 26., Rozher I.

Glocianus fennicus (Faust, 1894) - Látrány: Birkás-legelö, fühálózás, 2001. IV. 26., Podlussány A., Rozner I., Rozner Gy. 
Glocianus moelleri (Thomson, 1838) - Látrány: Birkás-legelö, 2000. IV. 20., Rozner Gy.

Glocianus punctiger (Gyllenhal, 1837) Látrány: Birkás-legelö, 2000. IV. 20., Rozner Gy.; Látrány: Kolláti-legelö, 2001. IV. 25., Rozner Gy.; Látrány: Birkás-legelő (4. számú terület), fühálózás, 2002. IV. 26., Podlussány A., Rozner I., Rozner Gy.

* Gymnetron aper Desbrochers des Loges, 1893 Látrány: Birkás-legelő (4. számú terület), fühálózás, 2002. IV. 26., Podlussány A., Rozner I., Rozner Gy.

Gymnetron asellus (Gravenhorst, 1807) Látrány: Birkás-legelő, fühálózás, 2000. VI. 4., Podlussány A., Rozner I., Rozner Gy.; Látrány: Birkás-lcgelö, fühálózás, 2001. IV. 26., Podlussány A., Rozner I., Rozner Gy.; Látrány: Birkás-legelö (4. számú terület), fühálózás, 2002. IV. 26., Podlussány A., Rozner I., Rozner Gy.; Látrány, 1999. IV. 14., Rozner Gy.; Látrány: Birkás-legelö, 2000. IV. 29., Rozner Gy.

Gymnetron labile (Herbst, 1795) - Látrány: Kolláti-legelö, 2000. VI. 3., Rozner I.; Látrány: Birkás-legelő, fühálózás, 2001. VI. 26., Rozner 1.; Látrány: Kolláti-legelö, fühálózás, 2001. X. 5., Podlussány A., Rozner 1., Rozner Gy.; Látrány: Kolláti-legelö, fühálózás, 2000. VI. 4., Podlussány A., Rozner I., Rozner Gy.; Látrány: Látránypuszta, fühálózás, 1998. VI. 27-28., Rozner l.

Gymnetron melanarium (Germar, 1821) Látrány: Látrányi-legelö, 2001. IV. 12., Szalóki D., Rozner Gy.; Látrány: Birkás-lcgelő, fühálózás, 2001. IV. 26., Podlussány A., Rozner I., Rozner Gy.; Látrány: Kolláti-legelő (1. számú terület), fühálózás, 2002. IV. 26., Podlussány A., Rozner I., Rozner Gy.; Látrány: Birkás-legelö, 1999. III. 5-31., talajcsapda, Rozner Gy.; Látrány, 2001. IV. 29., Szalóki D.

Gymnetron pascuorum (Gyllenhal, 1813) Látrány: Kolláti-legelő, 2000. VI. 3., Rozner I.; Látrány: Birkás-legelő, fühálózás, 2000. VI. 4., Podlussány A., Rozner I., Rozner Gy.; Látrány: Birkás-legelő, fühálózás, 2001. IV. 26., Podlussány A., Rozner 1., Rozner Gy.; Látrány: Kolláti-legelô ( 1 . számú terület), fühálózás, 2001. VII. 5., Merkl O.; Látrány: "dél", 2001. VIII. 24., Kondorosy E.; Látrány: Kolláti-legclő, fühálózás, 2001. X. 5., Podlussány A., Rozner I., Rozner Gy.; Látrány: Birkás-lcgelö (4. számú tcrület), fühálózás, 2002. IV. 26., Podlussány A., Rozner I., Rozner Gy.; Látrány, 1998. VI. 22., Rozner Gy.; Látrány: Kolláti-legelö, fühálózás, 2000. VI. 4., Podlussány A., Rozner I., Rozner Gy.; Látrány (2. számú terület), 2001. VII. 10., Kondorosy E.; Látrány: Látránypuszta, fühálózás, 1998. VI. 27-28., Rozner I.

Gymnetron pirazzolii (Stierlin, 1867) - Látrány: Kolláti-legelö, 2000. VI. 3., Rozner I.; Látrány: Kolláti-legelö, fühálózás, 2000. VI. 4., Podlussány A., Rozner I., Rozner Gy.

Gymnetron tetrum (Fabricius, 1792) - Látrány: Kolláti-legelö, 2000. VI. 3., Rozner I.; Látrány: Birkás-legelö, fühálózás, 2000. VI. 4., Podlussány A., Rozner I., Rozner Gy.; Látrány, 2001. V. 18., Szalóki
D.; Látrány: Birkás-legelö, fühálózás, 2001. VI. 26., Rozner I.; Látrány: Kolláti-legelő (1. számú terület), fühálózás, 2001. VII. 5., Merkl O.; Látrány (2. számú terület), 2001. VII. 10., Kondorosy E.

Hylobitelus transversovittatus (Goeze, 1777) Látrány, 1998. VI. 22., Rozner Gy.

Hypera arator (Linné, 1758) - Látrány: Birkáslegelő, fühálózás, 2001. X. 5., Podlussány A., Rozner I., Rozner Gy.

Hypera meles (Fabricius, 1792) - Látrány: Birkás-legelő, fühálózás, 2001. X. 5., Podlussány A., Rozner I., Rozner Gy.; Látrány, 1998. IV. 27., Rozner Gy. Hypera plantaginis (De Geer, 1775) - Látrány: Kolláti-legelő, fühálózás, 2000. V1. 4., Podlussány A., Rozner l., Rozner Gy.

Hypera postica (Gyllenhal, 1813) - Látrány: Birkás-lcgelö, fühálózás, 2001. X. 5., Podlussány A., Rozner I., Rozner Gy.

Hypera striata (Boheman, 1834) - Látrány: Látrányi-legelő, 2001. IV. 12., Szalóki D., Rozner Gy.; Lătrány: Birkás-legelö, fühálózás, 2001. X. 5., Podlussány A., Rozner 1., Rozner Gy.

Hypera suspiciosa (Herbst, 1795) - Látrány: Birkás-legelő, 2000. IV. 20., Rozner Gy.; Látrány: Kolláti-legelő, fühálózás, 2000. IV. 29., Rozner I.; Látrány, 2000. V. 13., Kondorosy E.; Látrány: Kolláti-legelö, 2000. V. 13., Kondorosy E., Rozner Gy.; Látrány, 1998. IV. 27., Rozner Gy.

Hypera viciae (Gyllenhal, 1813) - Látrány: Kolláti-lcgelő, fühálózás, 2000. IV. 29., Rozner I.; Látrány: Kolláti-legelo, 2000. V. 13., Kondorosy E., Rozner Gy.; Látrány: Birkás-legelő, fühálózás, 2001. IV. 26., Podlussány A., Rozner I., Rozner Gy.

Hypera zoilus (Scopoli, 1763) - Látrány: Birkáslegelô (4. számú terület), fühálózás, 2002. IV. 26. ., Podlussány A., Rozner I., Rozner Gy.

Isochnus populicola Silfverberg, 1977 - Látrány: Birkás-legclö, kopogtatás, 2000. VI. 4., Podlussány A., Rozner 1., Rozner Gy; Látrány: talajcsapda, 1998. IV. 24.-V. 15., Rozner Gy.; Látrány: Kollátilegelő, fühálózás, 2000. VI. 4., Podlussány A., Rozner I., Rozner Gy.

Larinus jaceae (Fabricius, 1775) - Látrány: Birkás-legelő, 2000. VI. 4., Podlussány A., Rozner I., Rozner Gy.; Látrány: Birkás-legelő, fühálózás, 2001. IV. 26., Podlussány A., Rozner I., Rozner Gy.

Larinus obtusus Gyllenhal, 1836 - Látrány, 2000. V. 13., Kondorosy E.; Látrány: Kolláti-legelő, 2000. V. 13., Kondorosy E., Rozner Gy.; Látrány: Kolláti-legelő, 2000. VI. 3., Rozner I.; Látrány: Birkás-legelǒ, fühálózás, 2001. IV. 26., Podlussány A., Rozner I., Rozner Gy.; Látrány: Kolláti-legelö, 2001. VI. 16., Rozner Gy.; Látrány (4. számú terület), 2001. VII. 3., Kondorosy E.; Látrány (6. számú terület), 2001. VII. 3., Kondorosy E.; Látrány: Kolláti-legelő (1. számú terület), fühálózás, 2001. VII. 5., Merkl O.; Látrány: "dél", 2001. VIIl. 24., Kondorosy E.; Látrány: Birkás-legelő, fühálózás, 2001. X. 5., Podlussány A., Rozner 1., Rozner Gy.; Látrány: 
Kolláti-legelö, fühálózás, 2001. X. 5., Podlussány A., Rozner I., Rozner Gy.; Látrány: Birkás-legelő (4. számú terület), fühálózás, 2002. IV. 26., Podlussány A., Rozner I., Rozner Gy.; Látrány: Látránypuszta, 1999. VII. 25., Rozner 1.; Látrány: Kolláti-legelő, fühálózás, 2000. VI. 4., Podlussány A., Rozner l., Rozner Gy.; Látrány (1. számú terület), 2001. VII. 10., Kondorosy E.; Látrány (2. számú terület), 2001. VIl. 10., Kondorosy E.; Látrány (3. számú terület), 2001. VII. 10., Kondorosy E.; Látrány: Látránypuszta, fühálózás, 2002. VI. 30., Merkl O.; Látrány (4. számú terület), 2001. VII. 8., Rozner Gy.

Larinus planus (Fabricius, 1792) - Látrány: Birkás-legelö, 2000. VI. 4., Podlussány A., Rozner I., Rozner Gy.; Látrány: Birkás-legelö, fühálózás, 2001. IV. 26., Podlussány A., Rozner I., Rozner Gy.

Larinus sturnus (Schaller, 1783) - Látrány: Kolláti-legelö, 2000. V. 13., Kondorosy E., Rozner Gy.; Látrány: Birkás-legelő, fühálózás, 2001. IV. 26., Podlussány A., Rozner I., Rozner Gy.

Larinus turbinatus Gyllenhal, 1836 - Látrány: Birkás-legelö, 2000. Vl. 4., Podlussány A., Rozner I., Rozner Gy.; Látrány: Birkás-legelő, fưhálózás, 2001. IV. 26., Podlussány A., Rozner I., Rozner Gy.; Látrány: Birkás-legelô (5. számú terület), fühálózás, 2002. V. 4., Mcrkl O.

Lepyrus capucinus (Schaller, 1783) - Látrány: Birkás-legclő (4. számú terület), kopogtatás, 2002. IV. 26., Podlussány A., Rozner I., Rozner Gy.; Látrány: Kolláti-legelő, talajcsapda, 1999. IV. 15-V. 22., Rozner Gy.

Lepyrus palustris (Scopoli, 1763) - Látrány: Birkás-legelö, Tetves-patak, 2001. IV. 25., Rozner Gy.; Látrány: talajcsapda, 1998. IV. 24.-V. 15., Rozner Gy.; Látrány: Látránypuszta, fühálózás, 1998. VI. 27 28., Rozner 1.; Látrány, 2001. IV. 12., Szalóki D.

Limobius borealis (Paykull, 1792) - Látrány: Kolláti-legelö, 2001. VI. 16., Rozner Gy.

Limnobaris dolorosa (Goeze, 1777) - Látrány: Birkás-legelö, fühálózás, 2001. IV. 26., Podlussány A., Rozner I., Rozner Gy.; Látrány: Birkás-legelő (4. számú terület), fühálózás, 2002. IV. 26., Podlussány A., Rozner I., Rozner Gy.; Látrány: Birkás-legelö, Tetves-patak, 2001. IV. 25., Rozner Gy.

Limnobaris t-album (Linné, 1758) - Látrány: Birkás-legclö, 2000. IV. 20., Rozner Gy.; Látrány: Kolláti-legelö, 2001. IV. 25., Rozner Gy.; Látrány: Kolláti-legelö, fühálózás, 2001. IV. 26., Podlussány A., Rozner I., Rozner Gy.; Látrány: Birkás-legelö (4. számú terület), fühálózás, 2002. IV. 26., Podlussány A., Rozner I., Rozner Gy.; Látrány: Látránypuszta, fühálózás, 1998. VI. 27-28., Rozner 1.

Liophloeus tessulatus (O. F. Müller, 1776) Látrány: Kolláti-legelő (1. számú terület), fühálózás, 2002. IV. 26., Podlussány A., Rozner I., Rozner Gy.; Látrány: Birkás-legclő (4. számú terület), fühálózás, 2002. IV. 26., Podlussány A., Rozner I., Rozner Gy.

Lixus angustatus (Fabricius, 1775) - Látrány, 2000. V. 13., Kondorosy E.; Látrány: Kolláti-legelö, 2000. V. 13., Kondorosy E., Rozner Gy.
Lixus brevipes Ch. Brisout de Barneville, 1866 Látrány: Kolláti-legelő, 2000. IV. 18., Rozner Gy.

Lixus elegantulus Boheman, 1843 - Látrány: Kolláti-legelő, fühálózás, 2000. VI. 4., Podlussány A., Rozner I., Rozner Gy.; Látrány: Látránypuszta, fühálózás, 2002. Vl. 30., Merkl O.

Lixus filiformis (Fabricius, 1781) - Látrány: Kolláti-legelö, 2000. Vl. 3., Rozner I.; Látrány: Birkás-legelő, fühálózás, 2000. VI. 4., Podlussány A., Rozner I., Rozner Gy.; Látrány: Kolláti-legelö, fühálózás, 2000. VI. 4., Podlussány A., Rozner I., Rozner Gy.

Lixus subtilis Boheman, 1836 - Látrány: Birkáslegelő, fühálózás, 2001. X. 5., Podlussány A., Rozner l., Rozner Gy.; Látrány: Kolláti-legelő, fühálózás, 2001. X. 5., Podlussány A., Rozner I., Rozner Gy.

Magdalis armigera (Foucroy, 1785) - Látrány: Birkás-legelö, kopogtatás, 2000. VI. 4., Podlussány A., Rozner I., Rozner Gy.; Látrány: Birkás-legelő (4. számú terület), kopogtatás, 2002. IV. 26., Podlussány A., Rozner I., Rozner Gy.

Magdalis cerasi (Linné, 1758) - Látrány: Kolláti-legelö, 2000. V. 13., Kondorosy E., Rozner Gy.; Látrány: Birkás-legelő, fühálózás, 2001. IV. 26., Podlussány A., Rozner l., Rozner Gy.

Magdalis memnonia (Gyllenhal, 1837) Látrány: Birkás-legelő, fühálózás, 2001. IV. 26., Podlussány A., Rozner I., Rozner Gy.

Magdalis rufa Gcrmar, 1824 - Látrány (1. számú terület), 2001. VII. 10., Kondorosy E.; Látrány: Birkás-legelö, 2001. Vl. 14., Rozner Gy.

Magdalis ruficornis (Linné, 1758) - Látrány: Kolláti-legelö, 2001. IV. 25., Rozner Gy.; Látrány: Birkás-legelő, fühálózás, 2001. IV. 26., Podlussány A., Rozner I., Rozner Gy.

Marmaropus besseri Gyllenhal, 1837 - Látrány: Látránypuszta, 1999. VII. 25., Rozner I.; Látrány: Kolláti-legelő, fühálózás, 2000. VI. 4., Podlussány A., Rozner I., Rozner Gy.

Mecinus janthinus (Germar, 1817) - Látrány, 1999. IV. 14., Rozner Gy.

Mecinus pyraster (Herbst, 1795) - Látrány, 2001. IV. 24., Rozner Gy.; Látrány: Birkás-legelö, fühálózás, 2001. IV. 26., Podlussány A., Rozner I., Rozner Gy.; Látrány: Birkás-legelö, 1999. III. 5-31., talajcsapda, Rozner Gy.; Látrány: Látránypuszta, 1999. VII. 25., Rozner I.

Minyops carinatus (Linné, 1767) - Látrány: Kolláti-legelö, 2000. IV. 18., Rozner Gy.

Mogulones cruciger (Herbst, 1784) - Látrány: Birkás-legelö, 2000. VI. 4., Podlussány A., Rozner l., Rozner Gy.; Látrány: Birkás-legelő (4. számú terület), kopogtatás, 2002. IV. 26., Podlussány A., Rozner l., Rozner Gy.; Látrány: Nyíres-legelő, fühálózás, 2002. IV. 26., Podlussány A., Rozner I., Rozner Gy.

*Mogulones cynoglossi (Frauenfeld, 1866) Látrány: Birkás-legelő (4. számú terület), fühálózás, 2002. IV. 26., Podlussány A., Rozner l., Rozner Gy.; Látrány: Nyíres-legelö, fühálózás, 2002. IV. 26., Podlussány A., Rozner I., Rozner Gy. 
Podlussány A., Rozner 1., Rozner Gy.; Látrány: Birkás-legelő, fühálózás, 2001. VI. 26., Rozner I.; Látrány: Kolláti-legelő (1. számú terület), fühálózás, 2002. IV. 26., Podlussány A., Rozner I., Rozner Gy.; Látrány: Birkás-legelő (4. számú terület), fühálózás, 2002. IV. 26., Podlussány A., Rozner l., Rozner Gy.; Látrány: Birkás-lcgelő, (fenyves), 2002. IV. 2.-16., talajcsapda, Rozner Gy.

Pelenomus waltoni (Boheman, 1843) - Látrány: Birkás-legelö, fühálózás, 2000. VI. 4., Podlussány A., Rozner l., Rozner Gy.

Peritelus familiaris Boheman, 1834 - Látrány: Kolláti-legelő, 2000. IV. 11., Rozner Gy.; Látrány: Kolláti-legelő, fühálózás, 2000. IV. 29., Rozner I.; Látrány: Látrányi-legelő, 2001. IV. 12., Szalóki D., Rozner Gy.; Látrány: Kolláti-legelő, fühálózás, 2001. IV. 26., Podlussány A., Rozner I., Rozner Gy.; Látrány: Birkás-lcgelö, fühálózás, 2001. IV. 26., Podlussány A., Rozner l., Rozner Gy.; Látrány, 2001. V. 18., Szalóki D.; Látrány: Kolláti-legelö (1. számú terület), fühálózás, 2002. IV. 26., Podlussány A., Rozner l., Rozner Gy.; Látrány: Birkás-legelő (4. számú terület), fühálózás, 2002. IV. 26., Podlussány A., Rozner I., Rozner Gy.; Látrány: Nyíres-legelö, fühálózás, 2002. IV. 26., Podlussány A., Rozner l., Rozner Gy.; Látrány: Birkás-legelő (5. számú terület), fühálózás, 2002. V. 4., Merkl O.; Látrány (2. számú terület), 2001. VII. 10., Kondorosy E.; Látrány, 2001. IV. 29., Szalóki D.; Látrány, 1999. IV. 14., Rozner Gy.

Phyllobius argentatus (Linné, 1758) - Látrány: Birkás-legelö, fühálózás, 2001. IV. 26., Podlussány A., Rozner I., Rozner Gy.; Látrány: Birkás-legelö (4. számú terület), fühálózás, 2002. IV. 26., Podlussány A., Rozner I., Rozner Gy.

Phyllobius betulinus (Bechstein et Scharfenberg, 1805) - Látrány: Kolláti-legelő, 2001. IV. 25., Rozner Gy.; Látrány: Kolláti-legelő, fühálózás, 2001. IV. 26. ., Podlussány A., Rozner I., Rozner Gy.; Látrány: Birkás-legelö, fühálózás, 2001. IV. 26., Podlussány A., Rozner I., Rozner Gy.; Látrány: Kolláti-legelő (1. számú terület), fühálózás, 2002. IV. 26., Podlussány A., Rozner I., Rozner Gy.; Látrány: Birkás-legelő (4. számú terület), fühálózás, 2002. IV. 26., Podlussány A., Rozner 1., Rozner Gy.; Látrány: Birkás-legelö, Tetves-patak, 2001. IV. 25., Rozner Gy.

Phyllobius glaucus (Scopoli, 1763) - Látrány: Birkás-legelö, fühálózás, 2001. IV. 26., Podlussány A., Rozner I., Rozner Gy.; Látrány: Kolláti-legelö (1. számú terülct), fühálózás, 2002. IV. 26., Podlussány A., Rozner l., Rozner Gy; Látrány: Birkás-legelő (4. számú terület), fühálózás, 2002. IV. 26., Podlussány A., Rozner 1., Rozner Gy.; Látrány: Birkás-legelö (5. számú terület), fühálózás, 2002. V. 4., Merkl O.

Phyllobius incanus Gyllenhal, 1834 - Látrány: Kolláti-legelő, fühálózás, 2000. IV. 29., Rozner I.

Phyllobius longipilis Boheman, 1843 - Látrány: Birkás-legelö, fühálózás, 2001. IV. 26., Podlussány A., Rozner I., Rozner Gy.
Phyllobius oblongus (Linné, 1758) - Látrány: Kolláti-legelő, fühálózás, 2000. IV. 29., Rozner I.; Látrány: Kolláti-legelö, fühálózás, 2001. IV. 26., Podlussány A., Rozner I., Rozner Gy.; Látrány: Birkás-legelö, fühálózás, 2001. IV. 26., Podlussány A., Rozner I., Rozner Gy.; Látrány: Kolláti-legelő (1. számú terület), fühálózás, 2002. IV. 26., Podlussány A., Rozner I., Rozner Gy.; Látrány: Birkás-legelő (4. számú terület), fühálózás, 2002. IV. 26., Podlussány A., Rozner I., Rozner Gy.; Látrány: Birkás-legelő (5. számú terület), fühálózás, 2002. V. 4., Merkl O.; Látrány, 2001. IV. 12., Szalóki D.

Phyllobius pomaceus Gyllenhal, 1834 - Látrány: Kolláti-legelô, fühálózás, 2001. IV. 26., Podlussány A., Rozner l., Rozner Gy.; Látrány: Birkás-legelő (4. számú terület), fưhálózás, 2002. IV. 26., Podlussány A., Rozner I., Rozner Gy.

Phyllobius pyri (Linné, 1758) - Látrány: Látrányi-legelő, 2001. IV. 12., Szalóki D., Rozner Gy.; Látrány, 2001. IV. 13., Kondorosy E.; Látrány: Kolláti-legelő, 2001. IV. 25., Rozner Gy; Látrány: Kolláti-legelö, fühálózás, 2001. IV. 26., Podlussány A., Rozner I., Rozner Gy.; Látrány: Birkás-legelö, fühálózás, 2001. IV. 26., Podlussány A., Rozner 1., Rozner Gy.; Látrány, 2001. V. 18., Szalóki D.; Látrány: Kolláti-legclő (1. számú terület), fühálózás 2002. IV. 26., Podlussány A., Rozner I., Rozner Gy.; Látrány: Birkás-legelő (4. számú terület), fühálózás, 2002. IV. 26., Podlussány A., Rozner I., Rozner Gy.; Látrány: Nyíres-legclö, fühálózás, 2002. IV, 26. Podlussány A., Rozner I., Rozner Gy.; Látrány: Birkás-lcgelő (5. számú terület), fühálózás, 2002. V. 4., Merkl O.; Látrány: Kolláti-legelő, talajcsapda, 1999. IV. 15-V. 22., Rozner Gy.; Látrány, 2001. IV. 12., Szalóki D.

Phyllobius seladonius Brullé, 1832 - Látrány: Kolláti-legelö, fühálózás, 2001. IV. 26., Podlussány A., Rozner I., Rozner Gy.

Phyllobius vespertinus (Fabricius, 1792) Látrány: Látrányi-legelö, 2001. IV. 12., Szalóki D., Rozner Gy.; Látrány: Kolláti-lcgelö, 2001. IV. 25., Rozner Gy.; Látrány: Kolláti-legelö, fühálózás, 2001. IV. 26., Podlussány A., Rozner I., Rozner Gy.; Látrány: Birkás-legelö, fühálózás, 2001. IV. 26., Podlussány A., Rozner I., Rozner Gy.; Látrány: Kolláti-legelö (1. számú terület), fưhálózás, 2002. IV. 26., Podlussány A., Rozner I., Rozner Gy.; Látrány: Birkás-legclö (4. számú terület), fühálózás, 2002. IV. 26., Podlussány A., Rozner I., Rozner Gy.; Látrány: talajcsapda, 1998. IV. 24.-V. 15., Rozner Gy.

Phyllobius virideaeris (Laicharting, 1781) Látrány: Kolláti-legelö, fühálózás, 2000. IV. 29., Rozner I.; Látrány: Kolláti-legelö, fühálózás, 2001. IV. 26., Podlussány A., Rozner I., Rozner Gy.; Látrány: Birkás-legelö, fühálózás, 2001. IV. 26., Podlussány A., Rozner I., Rozner Gy.; Látrány, 2001. V. 18., Szalóki D.; Látrány: Kolláti-legelő (1. számú terület), fühálózás, 2002. IV. 26., Podlussány A., Rozner I., Rozner Gy.; Látrány: Birkás-legelő (4. szá- 
mú terület), fühálózás, 2002. IV. 26., Podlussány A., Rozner I., Rozner Gy.; Látrány: Birkás-legelő (5. számú terület), fủhálózás, 2002. V. 4., Merkl O.; Látrány, 1998. VI. 22., Rozner Gy.; Látrány: Kolláti-legelö, fühálózás, 2000. VI. 4., Podlussány A., Rozner l., Rozner Gy.; Látrány: Birkás-legelō, (fenyves), 2002. IV. 2.-16., talajcsapda, Rozner Gy.

Pissodes pini (Linné, 1758) - Látrány: Kollátilegelö, kopogtatás, 2001. IV. 26., Podlussány A., Rozner I., Rozner Gy.

Polydrusus cervinus (Linné, 1758) - Látrány: Birkás-legclő, fühálózás, 2001. IV. 26., Podlussány A., Rozner I., Rozner Gy.

Polydrusus picus (Fabricius, 1792) - Látrány: Birkás-legelö, kopogtatás, 2000. VI. 4., Podlussány A., Rozner I., Rozner Gy.; Látrány: Birkás-legelö, fühálózás, 2001. IV. 26., Podlussány A., Rozner 1., Rozner Gy.; Látrány: Kolláti-legelö (1. számú terület), fühálózás, 2001. VIl. 5., Merkl O.; Látrány: Birkás-legelő (5. számú terület), fühálózás, 2002. V. 4., Merkl O. Látrány, 1998. VI. 22., Rozner Gy.; Látrány (1. számú terület), 2001. VII. 10., Kondorosy E.; Látrány: Birkás-legelö, 2001. VI. 14., Rozner Gy.

Polydrusus pterygomalis Boheman, 1840 Látrány: talajcsapda, 1998. IV. 24.-V. 15., Rozner Gy.

Polydrusus sericeus (Schaller, 1783) - Látrány

(2. számủ terület), 2001. VII. 10., Kondorosy E.

Polydrusus tereticollis (De Geer, 1775) Látrány: Birkás-legelő, 2000. IV. 20., Rozner Gy.; Látrány, 2000. V. 13., Kondorosy E.; Látrány: Kolláti-legelö, 2000. V. 13., Kondorosy E., Rozner Gy.

* Pseudomyllocerus sinuatus (Fabricius, 1801) Látrảny: Birkás-legelö, 1999. V. 22-VI. 24., talajcsapda, Rozner Gy.

Pseudorchestes ermischi Dieckmann, 1958 Látrány: Kolláti-legclö, 2000. VI. 3., Rozner I.; Látrány: Kolláti-legelő, fühálózás, 2001. X. 5., Podlussány A., Rozner I., Rozner Gy.

Pseudorchestes pratensis (Germar, 1821) Látrány: Kolláti-legelő, fühálózás, 2001. IV. 26., Podlussány A., Rozner I., Rozner Gy.; Látrány: Birkás-legelö, fühálózás, 2001. VI. 26., Rozner I.; Látrány: Birkás-legelő, fühálózás, 2001. X. 5., Podlussány A., Rozner I., Rozner Gy.; Látrány: Birkás-legelö (4. számú terület), fühálózás, 2002. IV. 26., Podlussány A., Rozner I., Rozner Gy.

Rhamphus oxyacanthae (Marsham, 1802) Látrány: Kolláti-lcgelő, fühálózás, 2001. IV. 26., Podlussány A., Rozner I., Rozner Gy.; Látrány: Birkás-legelö, fühálózás, 2001. IV. 26., Podlussány A., Rozner I., Rozner Gy.

Rhamphus pulicarius (Herbst, 1795) - Látrány: Kolláti-legelő (1. számú terület), fühálózás, 2002. IV. 26., Podlussány A., Rozner l., Rozner Gy.; Látrány: Kolláti-legelö, 1999. VII. 12., Rozner Gy.

Rhinoncus castor (Fabricius, 1792) - Látrány: Kolláti-legelö, 2000. VI. 3., Rozner I.; Látrány: Birkás-legelö, fühálózás, 2000. VI. 4., Podlussány A.,
Rozner I., Rozner Gy.; Látrány: Birkás-legelő, 1999. III. 5-31., talajcsapda, Rozner Gy.

Rhinoncus inconspectus (Herbst, 1795) Látrány: Birkás-legclő, 2001. VI. 26., fühálózás, Rozner I.

Rhinoncus pericarpius Linné, 1758) - Látrány: Birkás-legelö, fühálózás, 2000. Vl. 4., Podlussány A., Rozner I., Rozner Gy.; Látrány: Kolláti-legelö, 2001. IV. 25., Rozner Gy.; Látrány: Kolláti-legclő (1. számú terület), fühálózás, 2002. IV. 26., Podlussány A., Rozner I., Rozner Gy.; Látrány: Birkás-legelö (4. számú terület), fühálózás, 2002. IV. 26., Podlussány A., Rozner I., Rozner Gy.; Látrány: Nyíres-lcgelö, fühálózás, 2002. IV. 26., Podlussány A., Rozner 1., Rozner Gy.

Rhinocyllus conicus (Frölich, 1792) - Látrány: Birkás-legelő, fühálózás, 2000. VI. 4., Podlussány A., Rozner I., Rozner Gy.; Látrány: Birkás-legelö, fühálózás, 2001. IV. 26., Podlussány A., Rozner I., Rozner Gy.; Látrány: Birkás-legclö (4. számú terület), fühálózás, 2002. IV. 26., Podlussány A., Rozner I., Rozner Gy.; Látrány: Birkás-legelő (5. számú terület), fühálózás, 2002. V. 4., Mcrkl O.

Rhynchaenus testaceus (O. F. Müller, 1776) Látrány, 2001. IV. 13., Kondorosy E; Látrány: Kolláti-legelő, fühálózás, 2001. IV. 26., Podlussány A., Rozner I., Rozner Gy.; Látrány: Birkás-legelö, fühálózás, 2001. IV. 26., Podlussány A., Rozner I., Rozner Gy.; Látrány: Birkás-legclö (4. számú terület), fühálózás, 2002. IV. 26., Podlussány A., Rozner I., Rozner Gy.; Látrány: Birkás-legelö, 1999. III. 531., talajcsapda, Rozner Gy.

Rhyncolus elongatus (Gyllenhal, 1827) Látrány: Kolláti-legelö, fühálózás, 2001. IV. 26., Podlussány A., Rozner 1., Rozner Gy.; Làtrány, 2001. V. 18., Szalóki D.

Rutidosoma globulus (Hcrbst, 1795) - Látrány: Birkás-legelö, fühálózás, 2001. IV. 26., Podlussány A., Rozner I., Rozner Gy.

Sciaphilus asperatus (Bonsdorff, 1785) Látrány: Kolláti-legelö, fühálózás, 2000. IV. 29., Rozner I.; Látrány: Birkás-legelő, fühálózás, 2001. X. 5., Podlussány A., Rozner I., Rozner Gy.; Látrány: Birkás-legelő (4. számú terület), rostálás, 2002. IV. 26., Podlussány A., Rozner I., Rozner Gy.

Sibinia femoralis Germar, 1824 - Látrány: Kolláti-legelő, 2000. VI. 3., Rozner I.; Látrány: Birkás-legelõ, fühálózás, 2001. IV. 26., Podlussány A., Rozner I., Rozner Gy.; Látrány: Kolláti-legelő, 2001. V1. 16., Rozner Gy.; Látrány: Kolláti-legelő (1. számú terület), fühálózás, 2002. IV. 26., Podlussány A., Rozner l., Rozner Gy.; Látrány: Látránypuszta, 1999. VII. 25., Rozner I.; Látrány: Kolláti-legclö, fühálózás, 2000. VI. 4., Podlussány A., Rozner I., Rozner Gy.

Sibinia pellucens (Scopoli, 1772) - Látrány: Kolláti-lcgelő, fühálózás, 2001. IV. 26., Podlussány A., Rozner I., Rozner Gy.; Látrány: Birkás-legelö, fühálózás, 2001. IV. 26., Podlussány A., Rozner I., Rozner Gy; Látrány: Birkás-legelö, 2001. VII. 19., Rozner 1 . 
Sibinia tibialis (Gyllenhal, 1836) - Látrány: Kolláti-legelö, 2000. VI. 3., Rozner I.; Látrány: Látránypuszta, 1999. VIl. 25., Rozner I.

*Sibinia viscariae (Linné, 1761) - Látrány: Kolláti-legelő, fühálózás, 2001. IV. 26., Podlussány A., Rozner I., Rozner Gy.

Sitona ambiguus Gyllenhal, 1834 - Látrány: Látrányi-legelö, 2001. IV. 12., Szalóki D., Rozner Gy.; Látrány: Kolláti-legelő, 2001. IV. 25., Rozner Gy.; Látrány: Kolláti-legclő, fühálózás, 2001. IV. 26., Podlussány A., Rozner I., Rozner Gy.; Látrány: Birkás-legclö, fühálózás, 2001. IV. 26., Podlussány A., Rozner I., Rozner Gy.; Látrány: Kolláti-legelö, fühálózás, 2001. X. 5., Podlussány A., Rozner I., Rozner Gy.; Látrány: Kolláti-legelő (1. számú terület), fühálózás, 2002. IV. 26., Podlussány A., Rozner 1., Rozner Gy.; Látrány: Birkás-legelő (4. számú terület), fühálózás, 2002. IV. 26., Podlussány A., Rozner I., Rozner Gy.; Látrány: Birkás-legelö (5. számú terület), fühálózás, 2002. V. 4., Merkl O.; Látrány: Kolláti-legelő, fühálózás, 2000. Vl. 4., Podlussány A., Rozner 1., Rozner Gy.

Sitona hispidulus (Fabricius, 1776) - Látrány: Kolláti-legelő, 2000. IV. 11., Rozner Gy.; Látrány: Kolláti-legelö, fühálózás, 2001. IV. 26., Podlussány A., Rozner I., Rozner Gy.; Látrány: Birkás-legelö, fühálózás, 2001. IV. 26., Podlussány A., Rozner l., Rozner Gy.; Látrány: Birkás-legelő, fühálózás, 2001. X. 5., Podlussány A., Rozner I., Rozner Gy.; Látrány: Kolláti-legelő, fühálózás, 2001. X. 5., Podlussány A., Rozner I., Rozner Gy.; Látrány: Birkás-legelő (4. számú tcrület), fühálózás, 2002. IV. 26., Podlussány A., Rozner I., Rozner Gy.; Látrány: Kolláti-legelö, fühálózás, 2000. VI. 4., Podlussány A., Rozner I., Rozner Gy.; Látrány (1. számú terület), 2001. VI1. 10., Kondorosy E.

Sitona humeralis Stephens, 1831 - Látrány: Kolláti-legelö, 2000. IV. 11., Rozner Gy.; Látrány: Birkás-legelő, fühálózás, 2000. VI. 4., Podlussány A., Rozner l., Rozner Gy.; Látrány: Kolláti-legelö, 2001. IV. 25., Rozner Gy.; Látrány: Kolláti-legelő, fühálózás, 2001. IV. 26., Podlussány A., Rozner I., Rozncr Gy.; Látrány: Birkás-legelö, fühálózás, 2001. IV. 26., Podlussány A., Rozner I,, Rozner Gy.; Látrány: Birkás-legelő, fühálózás, 2001. X. 5., Podlussány A., Rozner 1., Rozner Gy.; Látrány: Kolláti-legelö, fühálózás, 2001. X. 5., Podlussány A., Rozner I., Rozner Gy.; Látrány: Kolláti-legelö (1. számú terület), fühálózás, 2002. IV. 26., Podlussány A., Rozner I., Rozner Gy.; Látrány: Birkás-legelő (4. számú terület), fühálózás, 2002. IV. 26., Podlussány A., Rozner I., Rozner Gy.; Látrány: Nyíres-legelő, fühálózás, 2002. IV. 26., Podlussány A., Rozner I., Rozner Gy.; Látrány: Birkás-legelö, Tetves-patak, 2001. IV. 25., Rozner Gy.; Látrány: Kolláti-legelő, 2001. III. 10., Rozner Gy.

Sitona inops Gyllenhal, 1832 - Látrány: Kollátilegclö, 2000. VI. 3,, Rozner I.; Látrány: Kolláti-legelö, 2001. IV. 25., Rozncr Gy.; Látrány: Kolláti-leg- clő, fühálózás, 2001. IV. 26., Podlussány A., Rozner I., Rozner Gy.; Látrány: Birkás-legelō, fühálózás, 2001. IV. 26., Podlussány A., Rozner I., Rozner Gy.; Látrány: Kolláti-legelő, fühálózás, 2000. VI. 4., Podlussány A., Rozner I., Rozner Gy.; Látrány, 1998. VIII. 22., Rozner Gy.

Sitona lepidus Gyllenhal, 1834 - Látrány: Kolláti-legelő, 2000. VI. 3., Rozner I.

Sitona lineatus (Linné, 1758) - Látrány: Kollátilegelö, 2001. IV. 25., Rozner Gy.; Látrány: Kollátilegelő, fühálózás, 2001. IV. 26., Podlussány A., Rozner I., Rozner Gy.; Látrány: Birkás-legelö, fühálózás, 2001. IV. 26., Podlussány A., Rozner I., Rozner Gy.; Látrány: Birkás-legelö (4. számú terület), fühálózás, 2002. IV. 26., Podlussány A., Rozner I., Rozner Gy.; Látrány: Birkás-legelő, 1999. III. 531., talajcsapda, Rozner Gy.; Látrány, 2001. IV. 29., Szalóki D.

Sitona longulus Gyllenhal, 1834 - Látrány: Kolláti-legelő, 2001. VI. 16., Rozner Gy.; Látrány: "dél", 2001. VIIl. 24., Kondorosy E,; Látrány: Kolláti-legelő, fühálózás, 2001. X. 5., Podlussány A., Rozner I., Rozner Gy.

Sitona macularius (Marsham, 1802) - Látrány: Kolláti-legelő, 2000. VI. 3., Rozner I.; Látrány: Kolláti-legelö, fühálózás, 2001. IV. 26., Podlussány A., Rozner l., Rozner Gy.; Látrány: Birkás-legelö, fühálózás, 2001. IV. 26., Podlussány A., Rozner I., Rozner Gy.; Látrány: Kolláti-legelő, fühálózás, 2000. VI. 4., Podlussány A., Rozner I., Rozner Gy.; Látrány, 1999. IV. 14., Rozner Gy.

Sitona ononidis Sharp, 1866 - Látrány: Birkáslegelő, 2000. IV. 20., Rozner Gy.; Látrány: Kollátilegelő, fühálózás, 2000. IV. 29., Rozner I.; Látrány: Kolláti-legelö, 2000. V. 13., Kondorosy E., Rozner Gy.; Látrány: Kolláti-legelö, fühálózás, 2001. IV. 26., Podlussány A., Rozner I., Rozner Gy.; Látrány: Birkás-lcgclő, fühálózás, 2001. IV. 26., Podlussány A., Rozner I., Rozner Gy.; Látrány: Kolláti-legelö, 2001. VI. 16., Rozner Gy.; Látrány (4. számú terület), 2001. VII. 3., Kondorosy E.; Látrány: Birkás-legelő, fühálózás, 2001. X. 5., Podlussány A., Rozner 1., Rozner Gy.; Látrány: Birkás-legelő (4. számú terület), fühálózás, 2002. IV. 26., Podlussány A., Rozner I., Rozner Gy.; Látrány (3. számú terület), 2001. VII. 10., Kondorosy E.; Látrány, 1999. IV. 14., Rozner Gy.; Látrány: Látránypuszta, fühálózás, 1998. VI. $27-$ 28., Rozner I.; Látrány (4. számú terület), 2001. VII. 8., Rozner Gy.

Sitona puncticollis Stcphens, 1831 - Látrány: Kolláti-legelő, 2000. IV. 11., Rozner Gy.; Látrány: Birkás-legelö, fühálózás, 2001. IV. 26., Podlussány A., Rozner l., Rozner Gy.; Látrány: "dél", 2001. VIIl. 24., Kondorosy E.; Látrány: Kolláti-legelő (1. számú terület), fühálózás, 2002. IV. 26., Podlussány A., Rozner I., Rozner Gy.; Látrány (1. számú terület), 2001. VII. 10., Kondorosy E.

Sitona striatellus Gyllenhal, 1834 - Látrány: Birkás-legclő, fühálózás, 2001. IV. 26., Podlussány A., 
Rozner I., Rozner Gy.; Látrány: Kolláti-legelö, fühálózás, 2001. IV. 26., Podlussány A., Rozner I., Rozner Gy. Sitona sulcifrons (Thunberg, 1798) - Látrány: Kolláti-legelő, fühálózás, 2000. IV. 29., Rozner I.; Látrány: Birkás-lcgelő, fühálózás, 2001. X. 5., Podlussány A., Rozner I., Rozner Gy.; Látrány: Kolláti-legelö, fühálózás, 2001. X. 5., Podlussány A., Rozner I., Rozner Gy.; Látrány: Birkás-legelő (4. számú terület), fühálózás, 2002. IV. 26., Podlussány A., Rozner I., Rozner Gy.

Sitona suturalis Stephens, 1831 - Látrány, 2000. V. 13., Kondorosy E.; Látrány: Kolláti-legelő, 2000. V. 13., Kondorosy E., Rozner Gy.; Látrány: Kollátilegelö, 2001. IV. 25., Rozner Gy.; Látrány: Birkás-legelö, fühálózás, 2001. IV. 26., Podlussány A., Rozner 1., Rozner Gy.; Látrány: Birkás-legelő, fühálózás, 2001. X. 5., Podlussány A., Rozner I., Rozner Gy.; Látrány: Birkás-legclő (4. számú tcrület), fühálózás, 2002. IV. 26., Podlussány A., Rozner I., Rozner Gy.; Látrány: Birkás-legclö, Tetves-patak, 2001. IV. 25., Rozner Gy.; Látrány: Birkás-legelö, 2001. IV. 25., Rozner Gy.

Sitona waterhousei Walton, 1846 - Látrány: Kolláti-legelö, 2000. VI. 3., Rozner I.; Látrány: Kolláti-legelö, fühálózás, 2001. X. 5., Podlussány A., Rozncr I., Rozner Gy.; Látrány, 1999. IV. 14., Rozner Gy. Smicronyx coecus (Reich, 1797) - Látrány: Kolláti-legelö, 2000. VI. 3., Rozner I.; Látrány: Kolláti-legelő, fühálózás, 2000. VI. 4., Podlussány A., Rozner I., Rozner Gy.

Smicronyx reichii (Gyllenhal; 1836) - Látrány, fénycsapda, 2001. VII. 11., Ábrahám L.

Stenocarus ruficornis (Stephens, 1831) Látrány: Birkás-legelő, fühálózás, 2001. X. 5., Podlussány A., Rozner I., Rozner Gy.; Látrány: Birkás-legelő (4. számú terület), fühálózás, 2002. IV. 26., Podlussány A., Rozner I., Rozner Gy.; Látrány: Birkás-legelö, 1999. IIl. 5-31., talajcsapda, Rozner Gy. Stomodes gyrosicollis Boheman, 1843 - Látrány: Birkás-legelö (4. számú terület), fühálózás, 2002. IV. 26., Podlussány A., Rozner I., Rozner Gy.

Strophosoma faber (Herbst, 1785) - Látrány, 2001. IV. 24., Rozner Gy.; Látrány: Birkás-legelő, fühálózás, 2001. IV. 26., Podlussány A., Rozner 1., Rozner Gy.; Látrány: Birkás-legelö, 2001. VII. 19., Rozner I.; Látrány: "dél", 2001. VIII. 24., Kondorosy E.; Látrány: Birkás-legelö, fühálózás, 2001. X. 5., Podlussány A., Rozner 1., Rozner Gy.; Látrány: Kolláti-legelö, fühálózás, 2001. X. 5., Podlussány A., Rozner 1., Rozner Gy.; Látrảny, 1998. VI. 22., Rozner Gy.; Látrány: Kolláti-legelő, 2001. III. 10., Rozncr Gy.; "Látrány-patak", 2001. VIII. 24., Kondorosy E.; Látrány: Látránypuszta, fühálózás, 2002. VI. 30., Mcrkl O.; Látrány: Birkás-legelő, 46²4 $04^{\prime \prime} \dot{E}$, $017^{\circ} 46^{\prime} 07^{\prime \prime} \mathrm{K}, 126 \mathrm{~m}$, talajcsapda, 2002. VI. 16., Szinetár Cs.

Strophosoma melanogrammum (Forster, 1771) Látrány: Birkás-legelő (4. számú terület), fühálózás, 2002. IV. 26., Podlussány A., Rozner I., Rozner Gy.
Tanymecus palliatus (Fabricius, 1787) - Látrány: Birkás-lcgelő, fühálózás, 2000. VI. 4., Podlussány A., Rozner I., Rozner Gy.; Látrány: Birkás-legelő, fühálózás, 2001. IV. 26., Podlussány A., Rozner I., Rozner Gy.; Látrány: Birkás-legelö (4. számú terület), fühálózás, 2002. IV. 26., Podlussány A., Rozner I., Rozner Gy.; Látrány (3. számú terület), 2001. VII. 10., Kondorosy E.

Tapinotus sellatus (Fabricius, 1794) - Látrány: Birkảs-legelö, fühálózás, 2001. IV. 26., Podlussány A., Rozner I., Rozner Gy.

Trachyphloeus aristatus (Gyllenhal, 1827) Látrány: Birkás-legelö, fühálózás, 2001. X. 5., Podlussány A., Rozner I., Rozner Gy; Látrány: Birkás-legelö (5. számú terület), fühálózás, 2002. V. 4., Merkl O.; Látrány: Birkás-legelö, talajcsapda, 1999. V. 22-VI. 24., Rozner Gy.; Látrány: Kolláti-legelő, talajcsapda, 1999. IV. 15-V. 22., Rozner Gy.; Látrány: Kolláti-legelö, $46^{\circ} 44^{\prime} 07^{\prime \prime}$ É, $017^{\circ} 46^{\prime} 20^{\prime \prime} \mathrm{K}, 131 \mathrm{~m}$ talajcsapda, 2002. VI. 16., Szinetár Cs.

Trichosirocalus troglodytes (Fabricius, 1787) Látrány: Birkás-legclö, fühálózás, 2001. IV. 26., Podlussány A., Rozner I., Rozner Gy; Látrány: Birkás-legcló, fühálózás, 2001. VI. 26., Rozner I.; Látrány: Kolláti-legelö (1. számú terület), fühálózás, 2002. IV. 26., Podlussány A., Rozner I., Rozner Gy.; Látrány: Birkás-legclö (4. számú terület), fühálózás, 2002. IV. 26., Podlussány A., Rozner I., Rozner Gy.; Látrány: Birkás-legelö, 1999. III. 5-31., talajcsapda, Rozner Gy.; Látrány (3. számú terület), 2001. VII. 10., Kondorosy E.

Tychius cuprifer (Panzer, 1799) - Látrány, 2001. IV. 29., Szalóki D.; Látrány: Látránypuszta, fúhálózás, 1998. VI. 27-28., Rozncr I.

Tychius flavus Becker, 1864 - Látrány: Kollátilcgelö, 2000. VI. 3., Rozner I.

Tychius medicaginis Ch. Brisout de Barneville, 1862 - Látrány: Kolláti-legelö, 2000. VI. 3., Rozner I.; Látrảny: Birkás-legelö, fühảlózás, 2001. IV. 26., Podlussány A., Rozner I., Rozner Gy.; Látrány: Kolláti-legelő, fühálózás, 2000. VI. 4., Podlussány A., Rozner I., Rozner Gy.; Látrány: Látránypuszta, fühálózás, 2002. VI. 30., Mcrkl O.

Tychius meliloti Stephens, 1831 - Látrány: Kolláti-lcgelő, 2000. VI. 3., Rozner 1.; Látrány: Birkás-legelö, fühálózás, 2000. VI. 4., Podlussány A., Rozner I., Rozner Gy.; Látrány: Birkás-legelő (5. számú terület), fühálózás, 2002. V. 4., Merkl O.; Látrány: Kolláti-legclő, fühálózás, 2000. VI. 4., Podlussány A., Rozner I., Rozner Gy.; Látrány, 2001. IV. 29., Szalóki D.

Tychius picirostris (Fabricius, 1787) - Látrány: Kolláti-legelö, 2000. VI. 3., Rozner I.; Látrány: Birkás-legelő, fühálózás, 2000. VI. 4., Podlussány A., Rozner I., Rozner Gy.; Látrány, 1998. VI. 22., Rozner Gy; Látrány: Kolláti-legelö, fühálózás, 2000. VI. 4., Podlussány A., Rozner I., Rozner Gy.; Látrány (1. számú terület), 2001. VII. 10., Kondorosy $\mathrm{E}$. 
Tychius quinquepunctatus (Linné, 1758) Látrány: Birkás-legelö, fühálózás, 2000. VI. 4., Podlussány A., Rozncr I., Rozner Gy.; Látrány, 1998. VI. 22., Rozner Gy.; Látrány: Látránypuszta, fühálózás, 1998. VI. 27-28., Rozner I.

Tychius squamulatus Gyllenhal, 1836 - Látrány, 1998. V1. 22., Rozner Gy.

Tychius stephensi Schönherr, 1836 - Látrány: Kolláti-legelö, 2000. VI. 3., Rozner l.; Látrány: Birkás-legelő, fühálózás, 2001. IV. 26., Podlussány A., Rozner I., Rozner Gy.; Látrány: Kolláti-legelő, fühálózás, 2000. VI. 4., Podlussány A., Rozner I., Rozner Gy.

\section{Dryophthoridae}

(meghatározta: Podlussány Attila)

Sitophilus oryzae (Linné, 1763) - Látrány: Látránypuszta, 1999. VIl. 25., Rozner I.; Látrány: Birkás-legelő, 1999. V. 22-VI. 24., talajcsapda, Rozner Gy.

\section{Scolytidae}

(meghatározta: Podlussány Attila)

Ernoporus tiliae (Panzer, 1793) - Látrány: Birkás-legelő, autós hálózás, késő délután, 2002. V. 4., Merkl O.

Leperisinus varius (Fabricius, 1775) - Látrány: Birkás-legelő, autós hálózás, késő délután, 2002. V. 4., Merkl O.

Orthotomicus laricis (Fabricius, 1792) - Látrány: Birkás-legelő, autós hálózás, késő délután, 2002. V. 4., Merkl O.
Orthotomicus robustus (Knotek, 1899) Látrány: Birkás-legelő, autós hálózás, késő délután, 2002. V. 4., Merkl O.

Orthotomicus suturalis (Gyllenhal, 1827) Látrány: Birkás-legelő, autós hálózás, késő délután, 2002. V. 4., Merkl O.

*Pityophthorus pityographus (Ratzeburg, 1837) - Látrány: Birkás-lcgelö, autós hálózás, késő délután, 2002. V. 4., Merkl O.

Pteleobius kraatzii (Eichhoff, 1864) - Látrány: Birkás-legelő, autós hálózás, késő délután, 2002. V. 4., Merkl O.

Pteleobius vittatus (Fabricius, 1787) - Látrány: Birkás-legelő, autós hálózás, késő délután, 2002. V. 4., Mcrkl O.

Scolytus rugulosus (Ph. W. J. Müller, 1818) Látrány: Birkás-legclő, 2001. X. 5., Podlussány A., Rozner I., Rozner Gy.

Taphrorychus bicolor (Herbst, 1793) - Látrány: Birkás-legelő, autós hálózás, késő délután, 2002. V. 4., Merkl O.

Xyleborinus saxesenii (Ratzeburg, 1837) Látrány: Birkás-legelö, autós hálózás, késő délután, 2002. V. 4., Merk! O.

Xyleborus dispar (Fabricius, 1792) - Látrány: Birkás-legelő (3. számú terület), 2002. III. 14.-IV. 2., Rozner Gy.

Xylocleptes bispinus (Duftschmid, 1825) Látrány: Birkás-legelő (4. számú terület), 2002. IV. 26., Podlussány A., Rozner I., Rozner Gy.

\section{Köszönetnyilvánítás}

A tanulmány alapját képező anyag gyüjtésében és meghatározásában a szerzőkön kívül mások is részt vettek; nevük a bevezetésben, illetve az egyes családok fajainak felsorolásánál olvasható. A Brachycerus foveicollis és a Glischrochilus quadripunctatus habitusképeit Pál János (Budapest) festette; e fajok elterjedési térképei Gubányi (2001) programja segítségével készültek. Munkájukat ezúton illesse köszönet. Merkl Ottó kutatásait az Országos Tudományos Kutatási Alap (OTKA T-034207) támogatta. 


\section{Irodalom}

Alonso-ZARAZAGA, M. A. \& LyAL, H. C. (1999): A world catalogue of families and genera of Curculionoidea (Insecta: Coleoptera) (Excepting Scolytidae and Platypodidae). - Entomopraxis, Barcelona, 315 pp.

CsABAI, Z. (2001): Somogy megye vízibogarainak katalógusa (Coleoptera: Haliplidae, Dytiscidae, Noteridae, Gyrinidae, Hydrophilidae, Hydraenidae). - In: Ábrahám, L. (ed.): Somogy fauna katalógusa. A XX. század végén Somogy megyéből ismertté vált állatfajok listája. (Catalogue of the fauna of Somogy county. A checklist of the known animal species in Somogy county at the end of 20th century.) Natura Somogyiensis 1. Somogy Megyei Múzeumok Igazgatósága, Kaposvár, pp, 145-153.

GARAMI, L. \& GARAMI, LNÉ (1997): Zöld utakon. Védett természeti értékeink útikalauza. - Mezőgazda Kiadó, Budapest, 427 pp.

GuBÁNYI, A. (2001) BioData - Maptools. [Computer programme.] ZooSystcm, Veszprémvarsány, Hungary.

Herman, L. H. (2001): Catalog of the Staphylinidac (Insecta: Coleoptera). 1758 to the end of the second Millennium. I. Introduction, history, biographical sketches, and omaliine group. - Bulletin of the American Museum of Natural History, Number 265: 1-649.

Lawrence, J. F. \& Newton, JR., A. F. 1995: Families and subfamilies of Colcoptera (with selected genera, notes, references and data on family-group names). Pp. 779-1006. - In: Pakaluk, J. \& Slipinski, S. A. (eds): Biology, Phylogeny, and Classification of Colcoptera: Papers Celebrating the 80th Birthday of Roy A. Crowson. Muzeum i Instytut Zoologii Pan, Warszawa, $1092 \mathrm{pp}$.

MERKL, O. (1996): The species of 27 beetle families (Coleoptera) from Örség (Western Hungary). In: Vig, K. (ed.): Natural History of Örség Landscape Conservation Area Il. - Savaria (A Vas Megyei Múzcumok Értesítôje) $32(2): 103-139$.

MERKL, O. (2001): Harmincnégy bogárcsalád Somogy megyei fajainak katalógusa (Coleoptera). (Catalogue of 34 beetle families (Colcoptera) of Somogy county, Hungary.) - In: Ábrahám, L. (cd.): Somogy fauna katalógusa. A XX. század végén Somogy megyéből ismertté vált állatfajok listája. (Catalogue of the fauna of Somogy county. A checklist of the known animal species in Somogy county at the end of 20th century.) Natura Somogyiensis 1. Somogy Megyei Múzeumok Igazgatósága, Kaposvár, pp. 191-212.

PodluSSÁNY, A. (2001): Somogy megye ormányosalkatú bogarainak katalógusa (Coleoptera: Curculionoidea). - In: Ábrahám, L. (ed.): Somogy fauna katalógusa. A XX. század végén Somogy megyéből ismertté vált állatfajok listaja. (Catalogue of the fauna of Somogy county. A checklist of the known animal species in Somogy county at the end of 20th century.) Natura Somogyiensis 1. Somogy Megyei Múzeumok Igazgatósága, Kaposvár, pp. 237-252.

RozNER, GY. (2001): Somogy megye dögbogár, sutabogár és lemezescsápú bogár faunája (Coleoptera: Silphidae, Histeridae, Lamellicornia). - In: Ábrahám, L. (ed.): Somogy fauna katalógusa. A XX. század végén Somogy megyéböl ismertté vált állatfajok listája. (Catalogue of the fauna of Somogy county. A checklist of the known animal species in Somogy county at the end of 20th century.) Natura Somogyiensis 1. Somogy Megyei Múzeumok Igazgatósága, Kaposvár, pp. 161-167.

RUDNER, J. (2001): Somogy megye tapogatósbogarainak és gödörkćsbogarainak katalógusa (Colcoptera: Staphylinidac: Pselaphinac, Scydmaenidac). - In: Ábrahám, L. (ed.): Somogy fauna katalógusa. A XX. század végén Somogy megyéböl ismertté vált állatfajok listája. (Catalogue of the fauna of Somogy county. A checklist of the known animal species in Somogy county at the end of 20th century.) Natura Somogyicnsis 1. Somogy Megyei Múzcumok Igazgatósága, Kaposvár, pp. 155-159.

SÁR, J., DudÁs, GY. \& MERKL, O. (2001): A lapos sárkánybogár (Pytho depressus) elsö bizonyított magyarországi elöfordulása a Villányi-hegységben (Colcoptera: Pythidac). (Discovery of Pytho depressus (Linnaeus, 1767) in the Villány Hills: first evidence to the occurrence of the species in Hungary (Coleoptera: Pythidac).) - Természetvédelmi Közlcményck 9: 201-207.

SzALóKI, D. (2001): Somogy megye lágytestü és felcmás lábfejízes bogarainak katalógusa (Coleoptera: Elateroidea (részben), Lymexyloidea, Cleroidea, Tenebrionoidea) - In: Ábrahám, L. (ed.): Somogy fauna katalógusa. A XX. század végén Somogy megyéböl ismertté vált állatfajok listája. (Cataloguc of the fauna of Somogy county. A checklist of the known animal species in Somogy county at the end of 20th century.) Natura Somogyiensis 1. Somogy Megyci Múzeumok Igazgatósága, Kaposvár, pp. 179-190. 


\title{
Species of 52 beetle families (Coleoptera) from the Látrányi Puszta Nature Conservation Area (Somogy county, Hungary)
}

\author{
Ottó Merkl, Attila Podlussány \& Dezsö Szalóki
}

The paper lists 552 beetle species belonging to 52 families of various subfamilies collected in the Látrányi Puszta Nature Conservation Area (Somogy county, South-Western Hungary, $46^{\circ} 44^{\prime} 00^{\prime \prime} \mathrm{N}, 17^{\circ} 46^{\prime} 00^{\prime \prime} \mathrm{E}$ ). The area is covered predominantly by sandy grasslands, with wet meadows in the depressions between the dunes. Willow and alder woods as well as plantations of Scotch pine are also present.

Most of the recorded species are widely distributed all over Hungary. The first reliably identified specimen of Carpelimus subtilis (Erichson, 1839) (Staphylinidae) from Hungary is recorded from this area. Cerocoma schreberi Fabricius, 1781 (Meloidae), Zonitis praeusta (Meloidae) Fabricius, 1792 and Brachycerus foveicollis Gyllenhal, 1833 (Brachyceridae) are typical elements of steppic grasslands. Pytho depressus (Linnaeus, 1767) (Pythidae) has been found in the pine plantation; this record represents the third locality of the species in Hungary. Seventy-two species (marked with * in the list of species) are reported for the first time from Somogy county. 